This document was prepared in conjunction with work accomplished under Contract No. DE-AC09-96SR18500 with the U. S. Department of Energy.

\title{
DISCLAIMER
}

This report was prepared as an account of work sponsored by an agency of the United States Government. Neither the United States Government nor any agency thereof, nor any of their employees, nor any of their contractors, subcontractors or their employees, makes any warranty, express or implied, or assumes any legal liability or responsibility for the accuracy, completeness, or any third party's use or the results of such use of any information, apparatus, product, or process disclosed, or represents that its use would not infringe privately owned rights. Reference herein to any specific commercial product, process, or service by trade name, trademark, manufacturer, or otherwise, does not necessarily constitute or imply its endorsement, recommendation, or favoring by the United States Government or any agency thereof or its contractors or subcontractors. The views and opinions of authors expressed herein do not necessarily state or reflect those of the United States Government or any agency thereof. 


\section{SINGLE-PASS FLOW THROUGH (SPFT) TESTING OF FLUIDIZED-BED STEAM REFORMING (FBSR) WASTE FORMS}

T.H. Lorier

J.M. Pareizs

C.M. Jantzen

August 2005

Westinghouse Savannah River Company Savannah River National Laboratory Aiken, SC 29808

Prepared for the U.S. Department of Energy Under Contract Number DEAC09-96SR18500

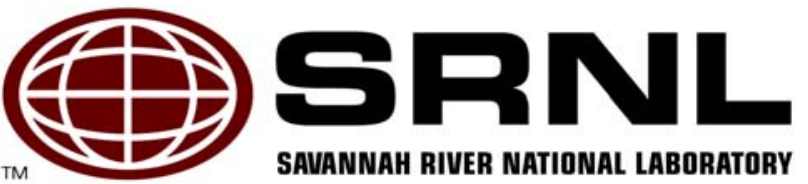




\section{DISCLAIMER}

This report was prepared by Westinghouse Savannah River Company (WSRC) for the United States Department of Energy under Contract No. DE-AC09-96SR18500 and is an account of work performed under that contract. Neither the United States Department of Energy, nor WSRC, nor any of their employees makes any warranty, expressed or implied, or assumes any legal liability or responsibility for the accuracy, completeness, or usefulness, of any information, apparatus, or product or process disclosed herein or represents that its use will not infringe privately owned rights. Reference herein to any specific commercial product, process, or service by trademark, name, manufacturer or otherwise does not necessarily constitute or imply endorsement, recommendation, or favoring of same by WSRC or by the United States Government or any agency thereof. The views and opinions of the authors expressed herein do not necessarily state or reflect those of the United States Government or any agency thereof.

Printed in the United States of America

Prepared For

U.S. Department of Energy 
Key Words: Single-pass flow through, steam reforming, durability, low-activity waste

Retention: Permanent

\title{
SINGLE-PASS FLOW THROUGH (SPFT) TESTING OF FLUIDIZED-BED STEAM REFORMING (FBSR) WASTE FORMS
}

\author{
T.H. Lorier \\ J.M. Pareizs \\ C.M. Jantzen
}

August 2005

Westinghouse Savannah River Company Savannah River National Laboratory Aiken, SC 29808 


\section{REVIEWS AND APPROVALS}

\section{AUTHOR:}

Troey H. Sarui by cand

Troy H. Lorier, Immobilization Technoløgy Section

for z Paveñ

John M. Pareizs, Immobilization Technology Section

Caral m tauter

Carol M. Jantzen, Immobilization Technology Section

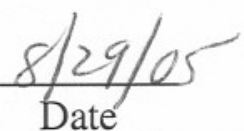

$8-30-05$

Date

TECHNICAL REVIEWER:

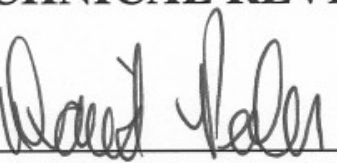

$9 / 1 / 05$

Date

David K. Peeler, Immobilization Technology Section

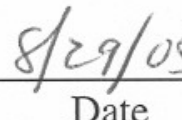

Date

\section{APPROVERS:}

Dhaven frome

Sharon L. Marra, Immobilization Technology Section

WW Hoetronkute

E.William Holtzscheiter, Immobilization Technology Section
$8 / 31 / 05$

Date

$9 / 2 / 85$ 


\section{EXECUTIVE SUMMARY}

Two samples of fluidized-bed steam reforming (FBSR) mineral waste form product were subjected to single-pass flow-through (SPFT) testing. Sample LAW 1123 resulted from pilot-scale FBSR processing with a Hanford Envelope A low-activity waste (LAW) simulant. Sample SBW 1173 resulted from pilot-scale FBSR processing with an Idaho National Laboratory (INL) simulant commonly referred to as sodium-bearing waste (SBW). The pilot-scale waste forms were made at the Science and Technology Applications Research (STAR) facility in Idaho Falls, Idaho. The durability of the two FBSR waste forms was assessed via the SPFT test in this study. Both samples were multiphase mineral waste forms, so the SPFT test results provide an overall release rate from the multiple mineral species in each sample and are dependent on the amount of each phase present and the mineralogy of the phases present. SPFT testing was performed at temperatures of $25^{\circ}, 40^{\circ}, 70^{\circ}$, and $90^{\circ} \mathrm{C}$ on LAW 1123 , while SBW 1173 was only tested at $70^{\circ}$ and $90^{\circ} \mathrm{C}$. The $70^{\circ}$ and $90^{\circ} \mathrm{C}$ data were compared to each other and the LAW-1123 results were compared to previous testing performed by the Pacific Northwest National Laboratory (PNNL) on a LAW Envelope C (high organic content) waste simulant.

The objectives of this study were to obtain forward dissolution rate data for both STAR FBSR bed products (using SPFT tests). Also, a qualitative comparison of the FBSR bed products to a glass waste form (specifically the low-activity reference material (LRM) glass) was performed. For these comparisons, the relative surface areas of the FBSR and glass products had to be measured. Due to the more porous and irregular surface of FBSR bed products, the surface area of the bed products was determined using the Brunauer, Emmett, and Teller (BET) measurement method. The surface area of a glass is much smoother and the calculated geometric surface area is typically used for determining dissolution behavior.

Presently there are no specifications or standard release rates that the FBSR tested materials have to meet, e.g. the data from the FBSR testing is normally used during subsequent Performance Assessment (PA) calculations. Since a PA calculation is not part of this study, the LAW and SBW steam reforming samples were compared to each other, to previous LAW FBSR SPFT results, and to the results from the LRM reference glass. The experimental durability data generated from this study suggests that an FBSR mineral waste form product would be an adequate alternative form to borosilicate glass. The tested FBSR mineral waste forms showed normalized release rates for matrix elements such as Si to be more than 200X slower than the LRM glass. However, further durability testing and mineral phase information is recommended to further substantiate these findings. 


\section{TABLE OF CONTENTS}

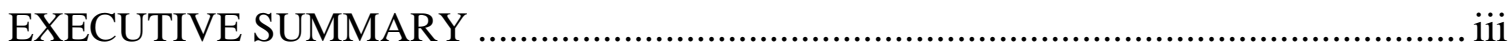

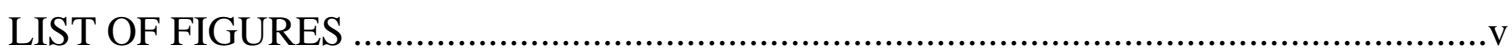

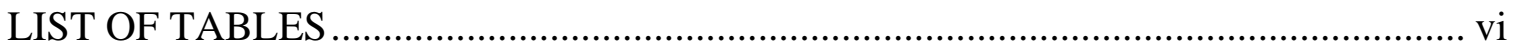

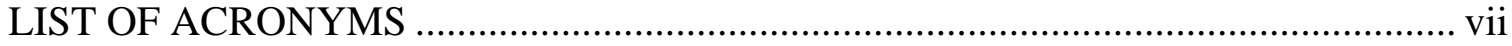

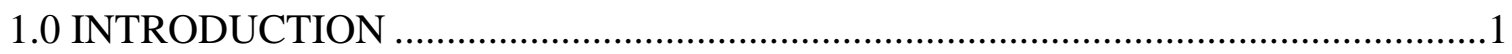

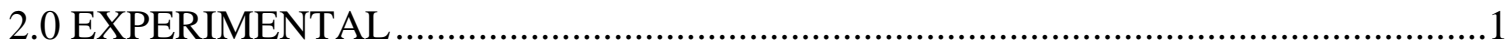

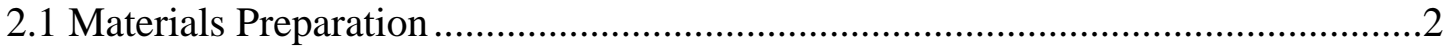

2.1.1 Chemical composition .........................................................................

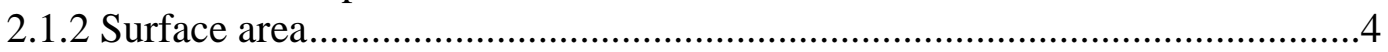

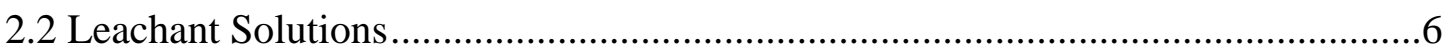

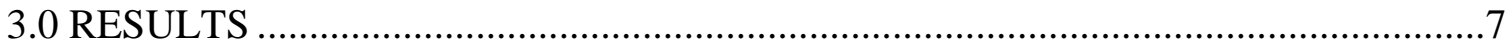

3.1 LAW 1123 Bed product testing ...................................................................

3.2 SBW 1173 Bed product testing......................................................................

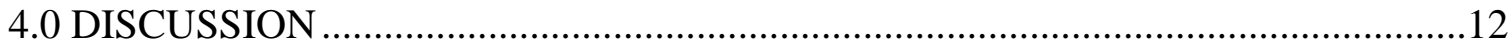

4.1 Comparison between LAW 1123 and SBW 1173 bed products............................15

4.2 Comparison of FBSR mineral waste forms to borosilicate glass waste forms .......17

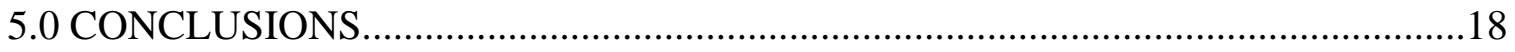

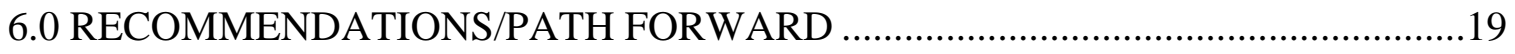

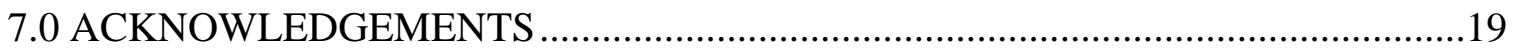

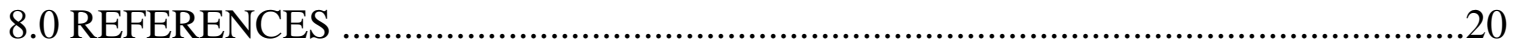

APPENDIX A. SPFTtest data of LAW 1123 bed product ............................................21

APPENDIX B. SPFT test data of SBW 1173 bed product...............................................34 


\section{LIST OF FIGURES}

Figure 2-1. Schematic of the single-pass flow-through test apparatus .....................................2

Figure 2-2. SEM photos of FBSR bed product to show the surface topography and porosity.......4

Figure 2-3. Microtrac particle-size distributions of FBSR bed products LAW 1123 and SBW 1173

Figure 3-1. Normalized release rate $\left(\log _{10}\right)$ as a function of time and leachant pH for LAW 1123 bed product SPFT experiments at $25^{\circ} \mathrm{C}$ and $0.2 \mathrm{~mL} / \mathrm{min}$ flow rate . .8

Figure 3-2. Normalized release rate $\left(\log _{10}\right)$ as a function of time and leachant $\mathrm{pH}$ for LAW 1123 bed product SPFT experiments at $40^{\circ} \mathrm{C}$ and $0.2 \mathrm{~mL} / \mathrm{min}$ flow rate

Figure 3-3. Normalized release rate $\left(\log _{10}\right)$ as a function of time and leachant $\mathrm{pH}$ for LAW 1123 bed product SPFT experiments at $70^{\circ} \mathrm{C}$ and $0.2 \mathrm{~mL} / \mathrm{min}$ flow rate

Figure 3-4. Normalized release rate $\left(\log _{10}\right)$ as a function of time and leachant $\mathrm{pH}$ for LAW 1123 bed product SPFT experiments at $90^{\circ} \mathrm{C}$ and $0.2 \mathrm{~mL} / \mathrm{min}$ flow rate

Figure 4-1. Normalized release rate $\left(\log _{10}\right)$ as a function of time and leachant $\mathrm{pH}$ for SBW 1173 bed product SPFT experiments at $70^{\circ} \mathrm{C}$ and $0.2 \mathrm{~mL} / \mathrm{min}$ flow rate

Figure 4-2. Normalized release rate $\left(\log _{10}\right)$ as a function of time and leachant $\mathrm{pH}$ for SBW 1173 bed product SPFT experiments at $90^{\circ} \mathrm{C}$ and $0.2 \mathrm{~mL} / \mathrm{min}$ flow rate

Figure 4-3. Plots of normalized release rate versus leachant $\mathrm{pH}$ for SPFT experiments - (a) LAW 1123 (7-day mark) and (b) SBW 1173 (6-day mark).

Figure 4-4. Plots of Re and S release versus pH for LAW 1123 and SBW 1173 (SPFT data at $\left.90^{\circ} \mathrm{C}\right)$

Figure 4-5. Plot of Re versus S release for LAW 1123 and SBW 1173 (SPFT data at $90^{\circ} \mathrm{C}$ ) .....17

Figure 4-6. Comparison of the dissolution rate of $\mathrm{Si}$ for $90^{\circ} \mathrm{C}$ data for glass and FBSR mineral products tested in this study. 


\section{LIST OF TABLES}

Table 2-1. Elemental and anion content of coal-free steam reformer bed products (Pareizs et al., 2005)

Table 2-2. Calculated and measured surface areas of SPFT materials. ......................................5

Table 2-3. Compositions of buffer solutions used for SPFT experiments.................................7

Table 4-1. Mineral phases identified (via XRD) in the tested FBSR bed products.....................16 


\section{LIST OF ACRONYMS}

\begin{tabular}{|c|c|}
\hline ADS & Analytical Development Section \\
\hline ASTM & American Society for Testing and Materials \\
\hline BET & Brunauer - Emmett - Teller \\
\hline DIW & DeIonized Water \\
\hline DOE-EM & Department of Energy - Environmental Management \\
\hline FBSR & Fluidized Bed Steam Reformer \\
\hline ICP-ES & Inductively-Coupled Plasma - Emission Spectroscopy \\
\hline ICP-MS & Inductively-Coupled Plasma - Mass Spectroscopy \\
\hline INL & Idaho National Laboratory \\
\hline LAW & Low-Activity Waste \\
\hline LRM & Low-activity Reference Material \\
\hline ML & Mobile Lab \\
\hline NAS & Sodium (Na) aluminosilicate (Na-Al-Si) \\
\hline PA & Performance Assessment \\
\hline PCT & Product Consistency Test \\
\hline PNNL & Pacific Northwest National Laboratory \\
\hline REDOX & REDuction-OXidation \\
\hline SAIC & Science Applications International Corporation \\
\hline SBW & Sodium-Bearing Waste \\
\hline SEM & Scanning Electron Microscope \\
\hline SPFT & Single-Pass Flow-Through \\
\hline SRNL & Savannah River National Laboratory \\
\hline STAR & Science and Technology Applications Research \\
\hline THAM & Tris Hydroxymethyl AminoMethane \\
\hline THOR & THermal Organic Reduction \\
\hline TTT & THOR $^{\text {sm }}$ Treatment Technologies \\
\hline XRD & X-Ray Diffraction \\
\hline
\end{tabular}




\subsection{INTRODUCTION}

Fluidized-Bed Steam Reforming (FBSR) technology is a moderate temperature, thermal process (650$750^{\circ} \mathrm{C}$ ) that destroys organic materials and produces a solid waste form through reaction with superheated steam. Steam reforming has long been used to produce hydrogen in the petrochemical industry, but more recently the process has been commercialized for radioactive waste treatment. In this process, slurried wastes plus clay co-reactant, a reductant, and a catalyst are injected into a hot fluidized-bed where the water in the wastes is evaporated, the organics are pyrolyzed and decomposed, and the nitrates and nitrites are decomposed to nitrogen gas. The solids left in the bed are chemically stable Na-Al-Si (NAS) minerals such as nepheline, sodalite, nosean, and an iron-rich spinel.

The FBSR pilot plant at the Science Applications International Corporation (SAIC) Science and Technology Applications Research (STAR) Center in Idaho Falls, Idaho, was used to perform mineralization tests of simulated Hanford low-activity waste (LAW) and simulated sodium-bearing waste (SBW). The purpose of the pilot runs was to demonstrate that the mineralized FBSR waste forms could be made from the basic LAW and acidic SBW wastes. The wastes were also of different Na molarity and different kaolin clay co-reactants with different Al:Si ratios were used to control the mineralogy and produce the desired mineral phases. The bed products were physically and chemically analyzed for composition and durability at the Savannah River National Laboratory (SRNL).

At the SRNL, the LAW bed product (designated LAW 1123) and SBW bed product (designated SBW 1173) were subjected to two durability tests - the Product Consistency Test (PCT; ASTM C1285-02) and the Single-Pass Flow-Through (SPFT) test. Only the results of the SPFT are documented in this report (PCT results are documented by Pareizs et al., 2005). The objectives of this study were to obtain forward dissolution rate data for both FBSR bed products via SPFT testing and compare the LAW 1123 to the SBW 1173 and to previous testing performed by the Pacific Northwest National Laboratory (PNNL) of an FBSR Hanford LAW Envelope C waste form. Also, a qualitative comparison of the FBSR bed products to a glass waste form (LRM glass) was performed. To do so, a surface area analysis was performed on the FBSR bed products due to the highly irregular and porous surface of the waste forms.

\subsection{EXPERIMENTAL}

SPFT experiments are designed to reach steady-state conditions between an aqueous solution (leachant) and the test material (waste form) by maintaining a constant solution $\mathrm{pH}$ and flow rate at constant temperature. Dilute solution conditions are maintained because the dissolution of silicate glasses and minerals is subject to the common ion effect. This effect can reduce the net rate of release relative to the rate in pure water. Thus, in the SPFT test the elements are released into solution from waste form dissolution by continuously introducing fresh leachant into the system which maintains the chemical affinity near zero. By monitoring the change in the dissolution rate over a range of temperatures and $\mathrm{pH}$ values the kinetic terms, such as the activation energy of dissolution can be determined which are used in kinetic rate law modeling and Performance Assessment (PA) modeling of waste forms.

The concentrations of certain cations in the leachates, along with the waste form composition and surface area, are used to calculate normalized release rates during the 14-day SPFT test duration. The cations monitored in SPFT tests in this study were Si, Al, Na, S, and Re. Though the releases of all five elements are plotted (see Section 3.0), the ones of main concern are S and Re - Re is a substitute for Tc-99 and previous testing of LAW steam reforming products has shown that $S$ release tracks closely with Re release (McGrail et al., 2003). The fate of S in the waste form is important because S limits waste loading in glass waste forms but appears to have a cage-like mineral host phase in the FBSR waste form product. 
SPFT tests were used to quantify the dissolution kinetics of the FBSR bed products produced for this study at the STAR facility. The SPFT is an open-system test where a solution, at a constant $\mathrm{pH}$ and flow rate, flows "through" (no recirculation of effluent) a reaction vessel that contains the test material set in an oven at constant temperature. Test durations vary based on the material dissolution behavior (i.e., the duration should be specified so that steady-state conditions are achieved between the test material and test solution. SPFT testing conducted in this study was performed at $25^{\circ} \mathrm{C}, 40^{\circ} \mathrm{C}, 70^{\circ} \mathrm{C}$, and $90^{\circ} \mathrm{C}$ with leachants at $\mathrm{pH} 7,8,9,10$, and 11 for up to 14-days. A schematic of the SPFT apparatus is given in Figure 2-1.

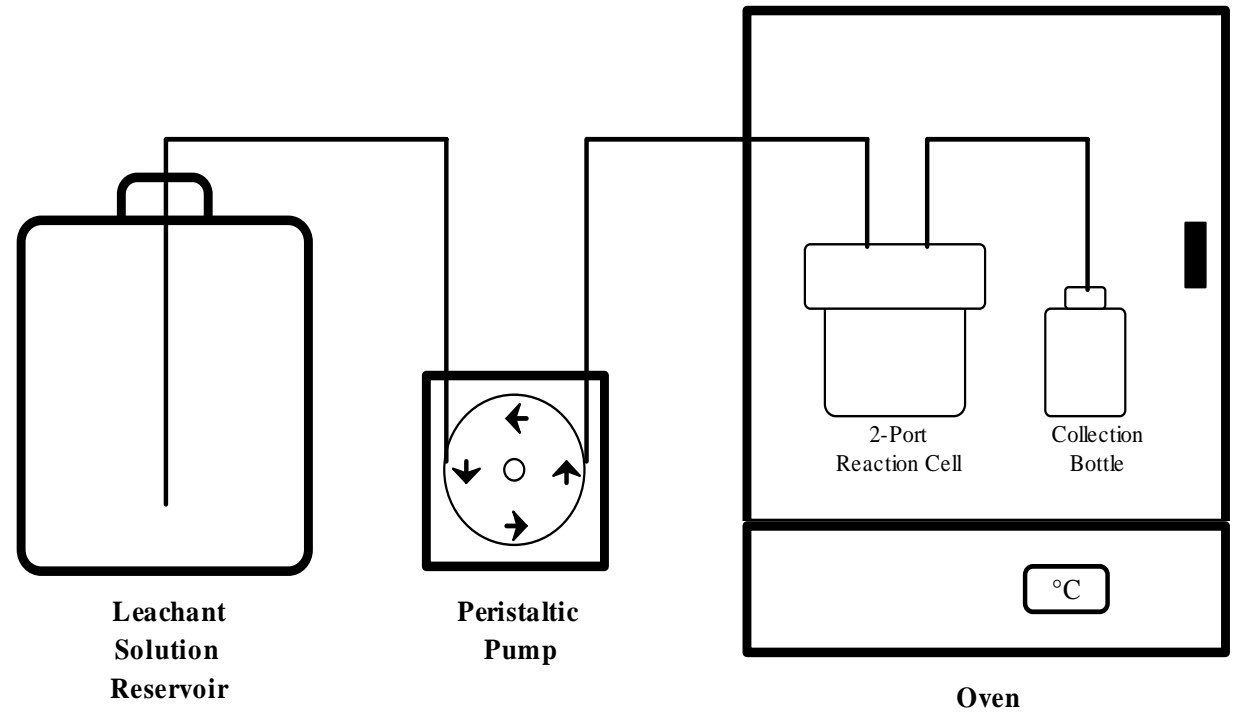

Figure 2-1. Schematic of the single-pass flow-through test apparatus

\subsection{Materials Preparation}

Two FBSR bed products were tested in this study - LAW 1123 bed product and SBW 1173 bed product. The LAW 1123 bed product was a result of mixing Hanford LAW Envelope A simulant with OptiKasT clay. The LAW FBSR test was run for 55 hours (Olson et al., 2004a). The SBW 1173 bed product was produced by mixing SBW simulant with Sagger XX clay, and resulted from a FBSR test that had a duration of 100 hours (Olson et al., 2004b). Both products were made at the STAR facility in a pilotscale steam reformer by a team of personnel from STAR, the Idaho National Laboratory (INL), and THermal Organic Reduction (THOR ${ }^{\mathrm{sm}}$ ) Treatment Technologies (TTT).

Coal was used as a reductant during FBSR processing at the STAR testing to facilitate the conversion of nitrates to nitrogen gas. An excess of coal is often used during processing and becomes part of the bed product unless it is removed by a second oxidizing reformer. The STAR pilot-scale facility did not have a second oxidizing reformer, so coal was admixed with the resulting mineral waste form product. The coal was removed from both the LAW 1123 and SBW 1173 bed products, prior to sizing and washing, for the SPFT tests. The removal of the carbon was done by heating the materials to $525^{\circ} \mathrm{C}$ overnight. The $525^{\circ} \mathrm{C}$ temperature is high enough remove the carbon in an oxidizing atmosphere, but not too high to change the composition or phase assemblages of the product (Bullock et al., 2002). Both FBSR bed products were then sized using an electric grinder and a ceramic mortar and pestle, and sieved to a -100 , +200 mesh size-fraction. The materials were then washed in accordance with procedure ASTM C1285 to remove adhering fines - washed six times with absolute ethanol in a sonication bath. Water was not used for the removal of the electrostatic fines so as to prevent the removal of any water-soluble phases 
prior to leach testing. After washing, the materials were placed in an oven at $90^{\circ} \mathrm{C}$ for drying overnight prior to being used for SPFT testing.

\subsubsection{Chemical composition}

Elemental and anion compositions of the LAW 1123 and SBW 1173 bed products were measured. Carbon was removed (by heating) from both bed products prior to elemental analysis (Pareizs et al., 2005). The amounts of unreacted coal, measured by weight loss on heating, in samples LAW 1123 and SBW 1173 were $5.57 \mathrm{wt} \%$ and $2.42 \mathrm{wt} \%$, respectively. For elemental composition, the solid samples were digested with a lithium tetraborate fusion at $1000^{\circ} \mathrm{C}$ followed by a hydrochloric acid uptake (Pareizs et al., 2005). The resulting solutions were analyzed for $\mathrm{Al}, \mathrm{Ca}, \mathrm{Cd}, \mathrm{Cr}, \mathrm{Cs}, \mathrm{Cu}, \mathrm{Fe}, \mathrm{I}, \mathrm{K}, \mathrm{Mg}$, Mn, Na, Ni, P, Pb, Re, S, Si, and Ti by Inductively-Coupled Plasma - Emission Spectroscopy (ICP-ES), and for Cs, La, Re, and I by Inductively-Coupled Plasma - Mass Spectroscopy (ICP-MS). Anion content $\left(\mathrm{F}, \mathrm{Cl}\right.$, and $\mathrm{NO}_{3}$ ) was determined from a sodium peroxide/sodium hydroxide fusion at $600^{\circ} \mathrm{C}$ followed by a water uptake (Pareizs et al., 2005). The measured compositions of the LAW 1123 and SBW 1173 bed products are listed in Table 2-1.

Table 2-1. Elemental and anion content of coal-free steam reformer bed products (Pareizs et al., 2005)

\begin{tabular}{|c|c|c|}
\hline Sample ID & LAW Bed $1123^{1}$ & SBW Bed 1173 \\
\hline $\mathrm{Al}(\mathrm{wt} \%)$ & 17.15 & 20.3 \\
\hline Ca (wt\%) & 1.65 & 2.71 \\
\hline Cd (wt\%) & $<0.001$ & $<0.01$ \\
\hline Cr (wt\%) & 0.08 & 0.068 \\
\hline Cs (wt\%) & $1.13 \times 10^{-4}$ & $3.07 \times 10^{-2}$ \\
\hline $\mathrm{Cu}(\mathrm{wt} \%)$ & 0.01 & 0.011 \\
\hline Fe (wt $\%)$ & 0.19 & 0.707 \\
\hline $\mathrm{I}(\mathrm{wt} \%)$ & $<2 \times 10^{-5}$ & Not Measured \\
\hline K (wt\%) & 0.25 & 3.29 \\
\hline La (wt\%) & $2.38 \times 10^{-6}$ & $5.71 \times 10^{-3}$ \\
\hline $\mathrm{Mg}(\mathrm{wt} \%)$ & 0.04 & 0.242 \\
\hline Mn (wt\%) & 0.03 & 0.275 \\
\hline Na (wt\%) & 14.96 & 12.3 \\
\hline $\mathrm{Ni}(\mathrm{wt} \%)$ & 0.01 & 0.04 \\
\hline $\mathrm{P}(\mathrm{wt} \%)$ & 0.2 & 0.375 \\
\hline $\mathrm{Pb}(\mathrm{wt} \%)$ & $<0.1$ & $<0.01$ \\
\hline $\operatorname{Re}(w t \%)$ & $4.1 \times 10^{-3}$ & $4.75 \times 10^{-3}$ \\
\hline S (wt\%) & 0.25 & 0.041 \\
\hline Si (wt\%) & 16.65 & 17.6 \\
\hline $\mathrm{Ti}(\mathrm{wt} \%)$ & 0.71 & 0.713 \\
\hline $\mathrm{F}^{-}(\mathrm{wt} \%)$ & $<0.1$ & $<0.1$ \\
\hline $\mathrm{Cl}^{-}(\mathrm{wt} \%)$ & 0.13 & 0.092 \\
\hline $\mathrm{NO}_{3}^{-}(\mathrm{wt} \%)$ & $<0.01$ & $<0.01$ \\
\hline $\mathrm{Fe}^{2+} / \Sigma \mathrm{Fe}^{2}$ & 0.28 & 0.81 \\
\hline
\end{tabular}

$1 \quad$ Pareizs et al. (2005) states LAW 1123 as LAW 1104. The LAW 1123 and LAW 1104 products are the same material - bed product after 55 hours of LAW FBSR processing - but subsampled at different times.

2 The $\mathrm{Fe}^{2+} / \Sigma \mathrm{Fe}$ ratio was determined on samples where the coal was removed by hand as heating to remove the carbon would have changed the ratio and the measurement did not appear sensitive to the traces of coal remaining. 


\subsubsection{Surface area}

Shown in Figure 2-2 are scanning electron microscope (SEM) micrographs of the LAW 1123 and SBW 1173 bed products. Photo (a) shows the particle shape and irregular surface topography typical of FBSR bed products, while photo (b) shows a sectioned particle and the internal porosity of the bed products.

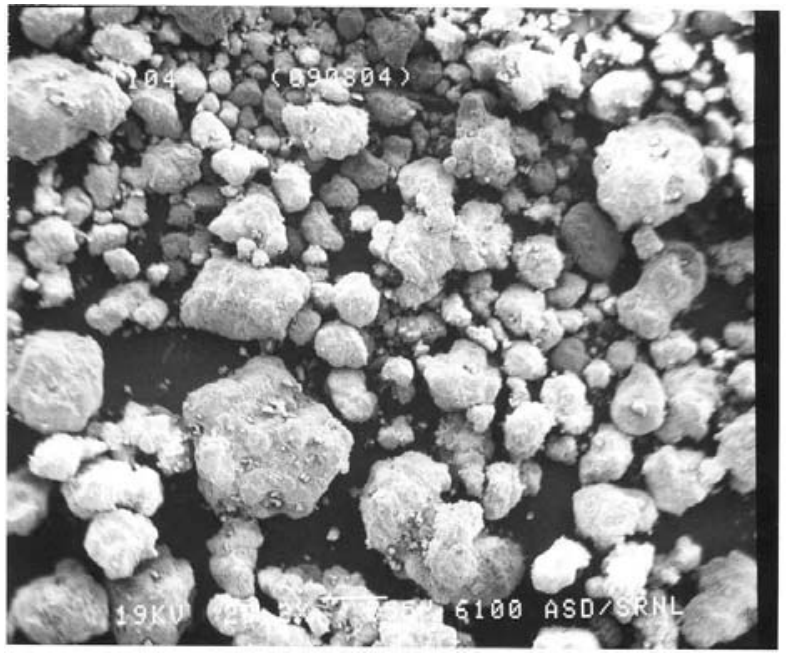

(a) 1123 Bed product

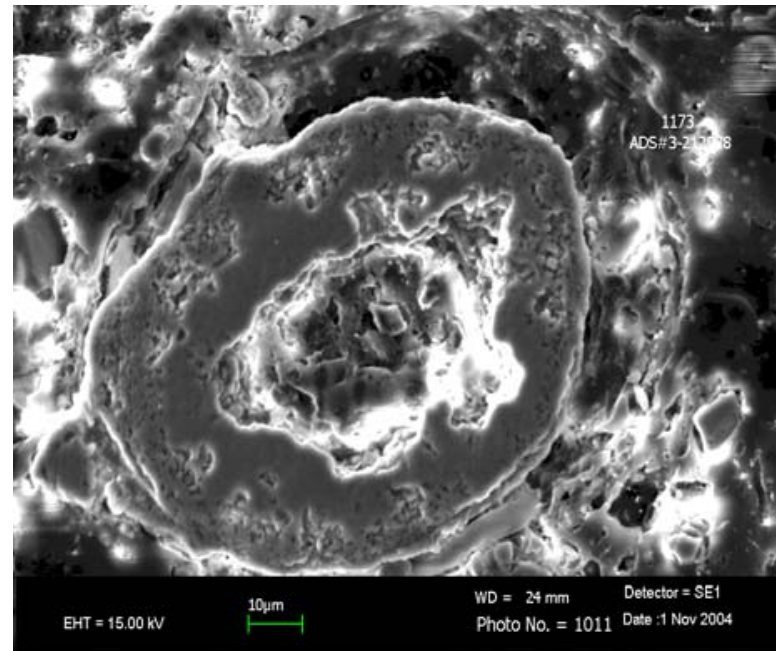

(b) 1173 Bed product (sectioned)

Figure 2-2. SEM photos of FBSR bed product to show the surface topography and porosity

Large uncertainties associated with the porosity of materials can give large discrepancies between a calculated geometric surface area and a measured surface area of a material. The geometric surface area (s) of both tested bed products was calculated using the material density $(\rho)$ and average particle diameter (d) (see Equation (1)).

$$
s=\frac{6}{\rho d}
$$

For comparison, the surface area of the tested FBSR bed products was measured using the Brunauer, Emmett, and Teller (BET) (Brunauer et al., 1938) method of gas adsorption. This method was recommended by McGrail et al. (2003) for surface area evaluation of FBSR waste forms. The BET measurement was performed on the bed products after the material had been crushed, sized, and cleaned. The surface areas, calculated (geometric) and measured (BET), of the bed products are shown in Table $2-2$. 
Table 2-2. Calculated and measured surface areas of FBSR materials (Pareizs et al., 2005).

\begin{tabular}{|c|c|c|c|}
\hline Material & $\begin{array}{c}\text { Calculated geometric } \\
\text { surface area }\left(\mathbf{m}^{\mathbf{2}} \mathbf{g}\right)\end{array}$ & $\begin{array}{c}\text { Measured }^{(\mathbf{b})} \mathbf{B E T} \\
\text { surface area }\left(\mathbf{m}^{\mathbf{2}} \mathbf{g}\right)\end{array}$ & $\begin{array}{c}\text { Surface roughness } \\
\left(\mathbf{S A}_{\text {meas }} \mathbf{S A}_{\text {geo }}\right)\end{array}$ \\
\hline $\begin{array}{c}\text { LAW 1123 } \\
\text { Bed product }\end{array}$ & 0.0212 & 4.427 & 209 \\
\hline $\begin{array}{c}\text { SBW 1173 } \\
\text { Bed product }\end{array}$ & 0.0194 & 2.358 & 121.5 \\
\hline
\end{tabular}

(a) The geometric surface area was calculated using the average particle size and the material's density (see Appendix X1 in ASTM C1285-02 as an example).

(b) The measured surface area was determined via the BET method using nitrogen gas. The bed products had been sized and cleaned prior to the BET measurement.

For both FBSR bed products, the measured BET surface area was greater than the geometric surface area. The ratio of the measured surface area using gas adsorption to the geometric surface area has been defined as surface roughness (Helgeson et al., 1984; Brantley and Mellott, 2000). The BET surface area for the LAW 1123 bed product is over 200 times greater than the geometric, and more than 120 times greater for the SBW 1173 bed product. The surface roughness differs from unity (1) because of surface topography and porosity (see Figure 2-2). Since a geometric surface area of FBSR particles could greatly underestimate the "real" surface area, the measured BET surface area was used for all dissolution rate calculations for this study".

In addition to the surface area of the FBSR waste forms, the particle-size distribution was analyzed for both samples LAW 1123 and SBW 1173. Particle-size distribution analyses were performed to ensure Gaussian distribution of the particles. The particle-size distributions were measured after the samples had been sized and washed. The average particle size of LAW 1123 was $127 \mu \mathrm{m}$ and $139 \mu \mathrm{m}$ for SBW 1173 as measured by Microtrac. Plots of the particle-size distributions of samples 1123 and 1173 are shown in Figure 2-3.

3 This facilitates comparison with data from McGrail et al. (2003), who also used BET surface area in durability testing of FBSR waste forms. The BET surface area of the SBW 1173 obtained in this study was very similar to the surface area reported by McGrail et al. (2003). 


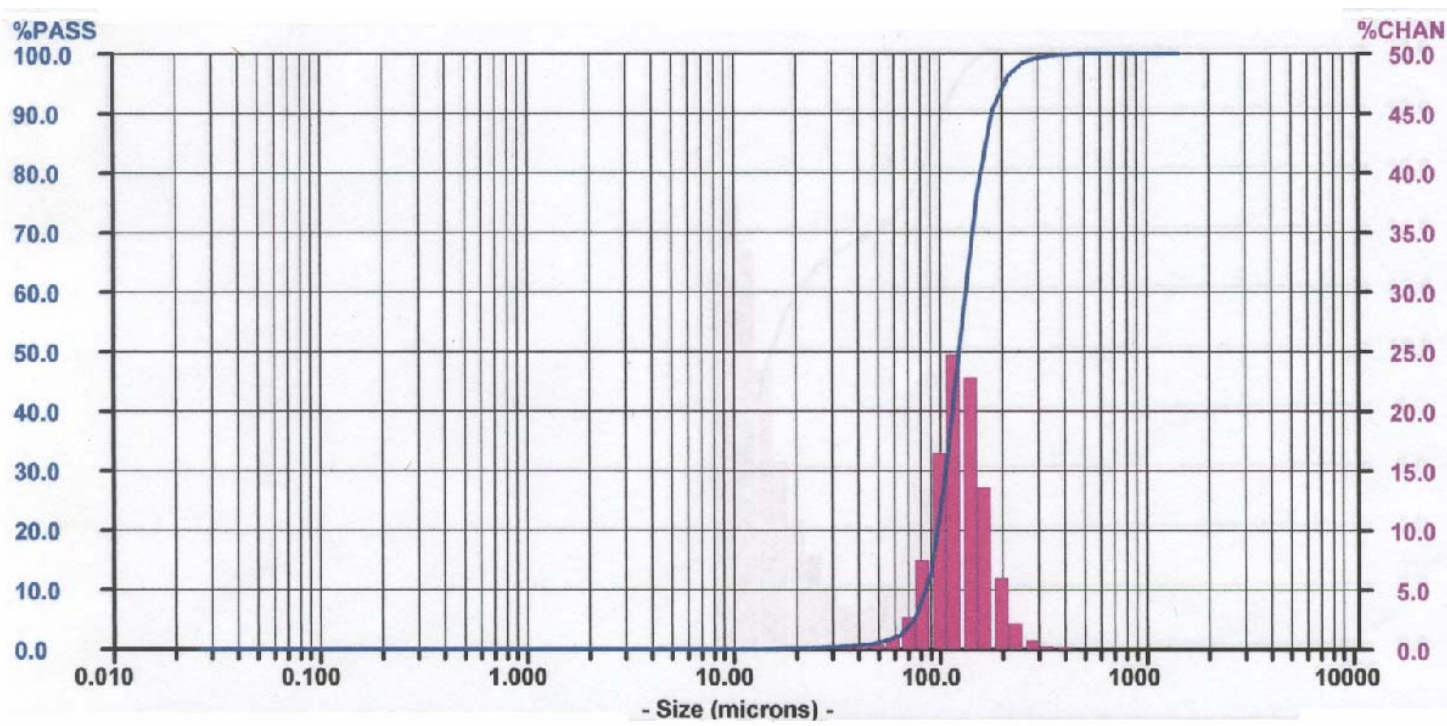

Sample 1123

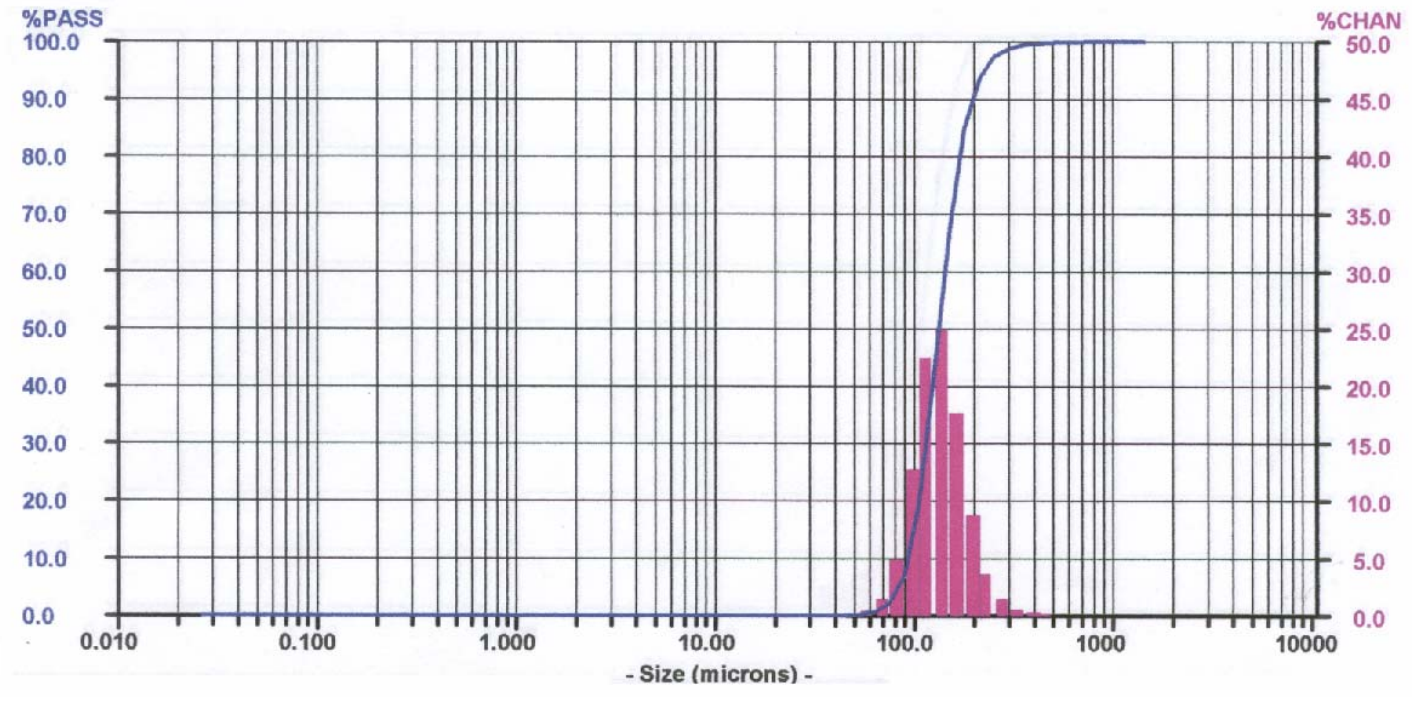

Sample 1173

Figure 2-3. Microtrac particle-size distributions of FBSR bed products LAW 1123 and SBW 1173

\subsection{Leachant Solutions}

Five solutions, listed in Table 2-3, were used for the SPFT testing in this study to control the pH (McGrail et al., 2003). SPFT testing controls the rate of leaching via $\mathrm{pH}$ buffer solutions. Small amounts of organic THAM (tris hydroxymethyl aminomethane) were added to deionized water (DIW) along with minor amounts of nitric acid in order to make the neutral to slightly basic solutions ( $\mathrm{pH} \approx 7,8,9$, and 10 ). Alkaline solutions $(\mathrm{pH} \approx 11)$ were made by adding small amounts of $\mathrm{LiCl}$ and $\mathrm{LiOH}$ to DIW. All solution compositions used are listed in Table 2-3. 
Table 2-3. Compositions of buffer solutions used for SPFT experiments.

\begin{tabular}{|c|c|c|}
\hline Solution \# & Composition & Approximate $\mathbf{p H}^{(\mathrm{b})}$ \\
\hline 1 & $0.01 \mathrm{M} \mathrm{TRIS}^{(\mathrm{a})}+0.0093 \mathrm{M} \mathrm{HNO}_{3}$ & 7 \\
\hline 2 & $0.01 \mathrm{M}$ TRIS + $0.0059 \mathrm{M} \mathrm{HNO}_{3}$ & 8 \\
\hline 3 & $0.05 \mathrm{M}$ TRIS + $0.0079 \mathrm{M} \mathrm{HNO}_{3}$ & 9 \\
\hline 4 & 0.05 M TRIS & 10 \\
\hline 5 & $0.01 \mathrm{M} \mathrm{LiCl}+0.0107 \mathrm{M} \mathrm{LiOH}$ & 11 \\
\hline
\end{tabular}

The flow rate for all SPFT tests conducted for this study was $0.2 \mathrm{~mL} / \mathrm{min}^{4}$ ( $288 \mathrm{~mL} /$ day). McGrail et al. (2003) tested a maximum flow rate of $200 \mathrm{~mL} /$ day $(0.14 \mathrm{~mL} / \mathrm{min})$. The $0.2 \mathrm{~mL} / \mathrm{min}$ flow rate was chosen because of the expected decline in release rate with decreasing flow rate (McGrail et al., 2003). Also, as stated by McGrail et al. (2003) and the SPFT procedure (ASTM, draft), higher flow rates would ensure there would be no feedback from the leachant solutions. Sampling began on the third day of each test in order to allow the system to reach steady-state conditions, and then continued every other day, with the exception of weekends, until test completion - the last day of sampling was always day 14. Once collected, each sample was analyzed for the concentrations of $\mathrm{Si}, \mathrm{Al}, \mathrm{Na}$, and $\mathrm{S}$ via ICP-ES, and for Re via ICP-MS.

\subsection{RESULTS}

The equation used to calculate the rate of dissolution for all SPFT testing in this study was Equation (2):

$$
\text { rate }=\left(C_{i}-C_{i}^{\circ}\right) \bullet\left(F / S^{\circ}\right) / f_{i}
$$

where $C_{i}$ is the steady-state concentration of component $i$ measured in the effluent solution, $C_{i}{ }^{\circ}$ is the background concentration of component $i$ in the test solution measured in a blank test, $F$ is the solution flow rate, $S^{\circ}$ is the surface area of the sample that is exposed to solution, and $f_{i}$ is the mass fraction of component $i$ in the test material. For this study, the measured components $i$ were Si, Al, Na, S, and Re.

\subsection{LAW 1123 Bed product testing}

Detailed results of each test with the LAW 1123 bed product are provided in Appendix A. Plotted in Figure 3-1, Figure 3-2, Figure 3-3, and Figure 3-4, are the temporal release behaviors of $\mathrm{Si}, \mathrm{Al}, \mathrm{Na}$, S, and Re from the 1123 bed product at room temperature $\left(25^{\circ} \mathrm{C}\right), 40^{\circ} \mathrm{C}, 70^{\circ} \mathrm{C}$, and $90^{\circ} \mathrm{C}$, respectively. Only two analyses were made for Re for each test in this study due to previous observations by McGrail et al. (2003) that the Re release behavior appeared unaffected over test duration. Each SPFT test was performed in duplicate and the average of the datasets is displayed (see Figures 3-1 through 3-4) along with the standard deviations for $\mathrm{Re}$ and $\mathrm{Al}$, the elements that showed the highest variability in the leachate replicates. The averages and standard deviations for all of the elemental releases are tabulated in Appendix A.

\footnotetext{
${ }^{4}$ The flow rate is a variable in SPFT testing, but was set at $0.2 \mathrm{~mL} / \mathrm{min}$ for all SPFT tests conducted.
} 

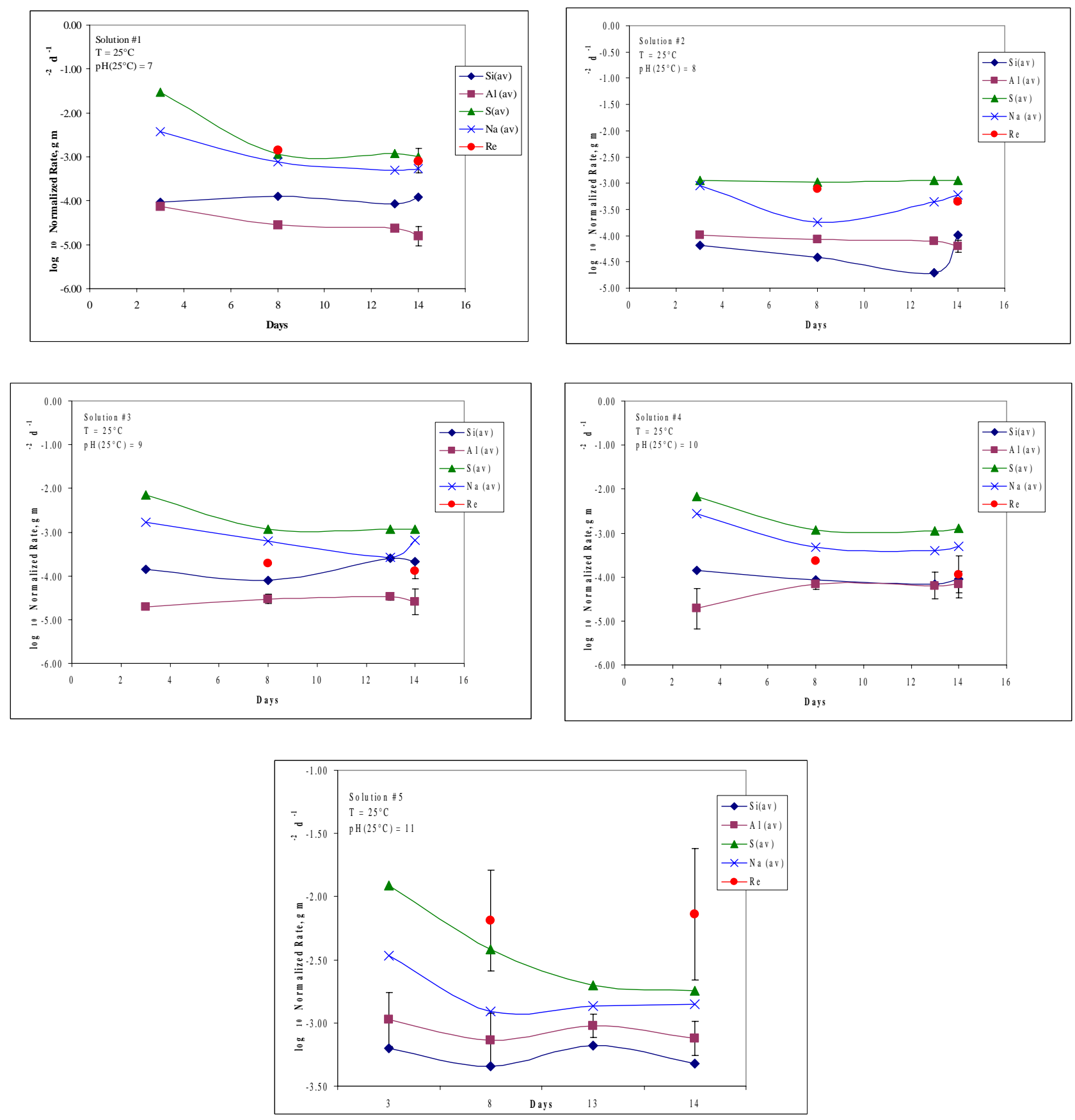

Figure 3-1. Normalized release rate $\left(\log _{10}\right)$ as a function of time and leachant pH for LAW 1123 bed product SPFT experiments at $25^{\circ} \mathrm{C}$ and $0.2 \mathrm{~mL} / \mathrm{min}$ flow rate. The average of the datasets given in the Appendices are plotted along with the standard deviations for Re and $\mathrm{Al}$, the elements that showed the highest variability in the leachate replicates. 

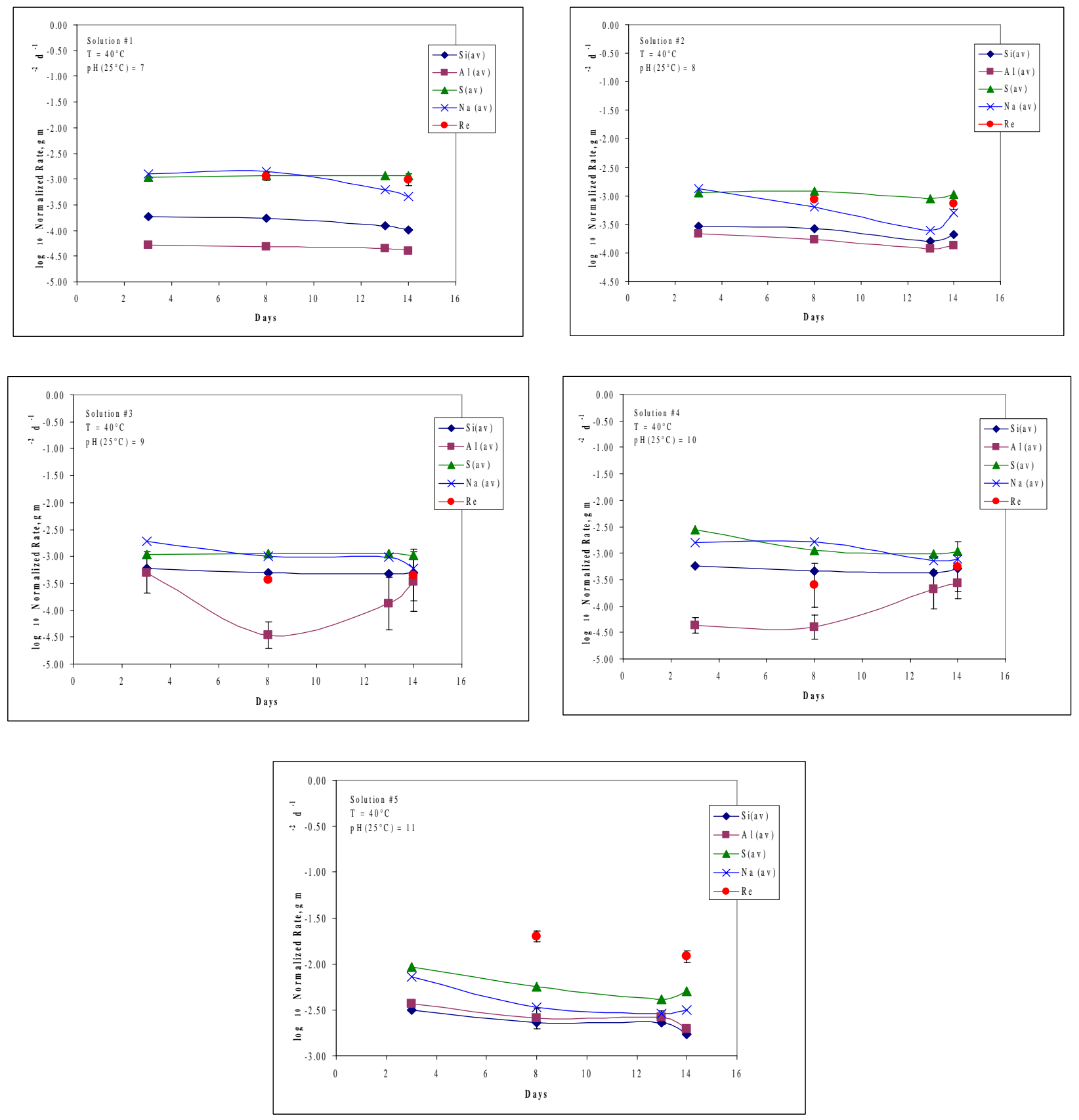

Figure 3-2. Normalized release rate $\left(\log _{10}\right)$ as a function of time and leachant pH for LAW 1123 bed product SPFT experiments at $40^{\circ} \mathrm{C}^{5}$ and $0.2 \mathrm{~mL} / \mathrm{min}$ flow rate. The average of the datasets given in the Appendices are plotted along with the standard deviations for Re and Al, the elements that showed the highest variability in the leachate replicates.

5 Some data points are missing due to concentration in test cell less than concentration in reference cell (as per ASTM SPFT procedure (DRAFT)). For example, at $\mathrm{pH} 7$ the measured concentration of $\mathrm{Al}$ in the reference cell was greater than the test cell at day 3 . 

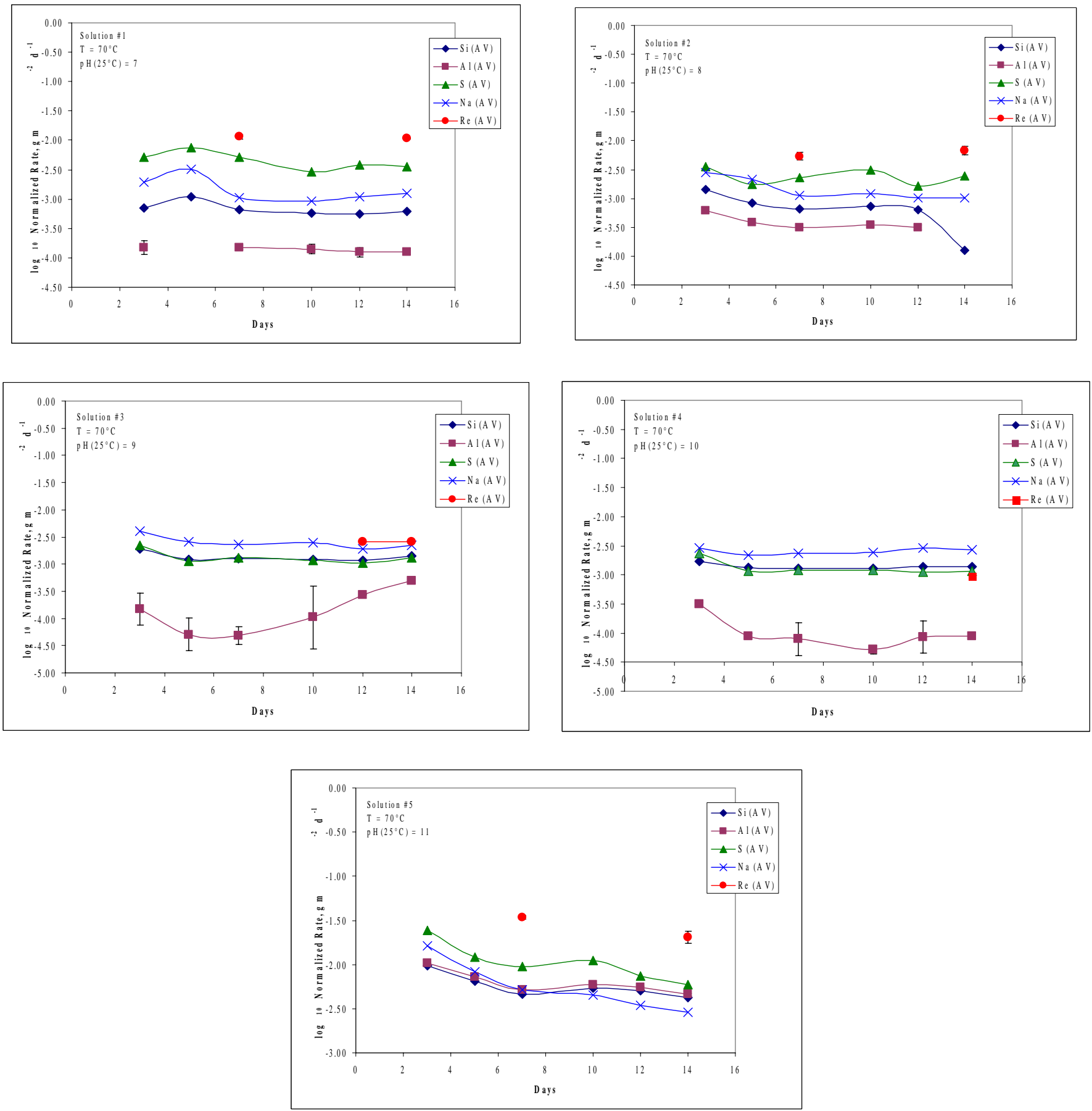

Figure 3-3. Normalized release rate $\left(\log _{10}\right)$ as a function of time and leachant $\mathrm{pH}$ for LAW 1123 bed product SPFT experiments at $70^{\circ} \mathrm{C}^{6}$ and $0.2 \mathrm{~mL} / \mathrm{min}$ flow rate. The average of the datasets given in the Appendices are plotted along with the standard deviations for $\mathrm{Re}$ and $\mathrm{Al}$, the elements that showed the highest variability in the leachate replicates

6 Some data points are missing due to the concentration in test cell being less than concentration in reference cell. For $\mathrm{Al}$ at day 5 in $\mathrm{pH} 7$ and day $14 \mathrm{in} \mathrm{pH}$ 8, the measured concentration was greater in the reference cell than in the test cell. Similar results occurred for Re at $\mathrm{pH} 9$ and 10. At pH 10, there was not enough sample in the collection bottle at day 7 to analyze for any element (line pulled out of leachant reservoir). 

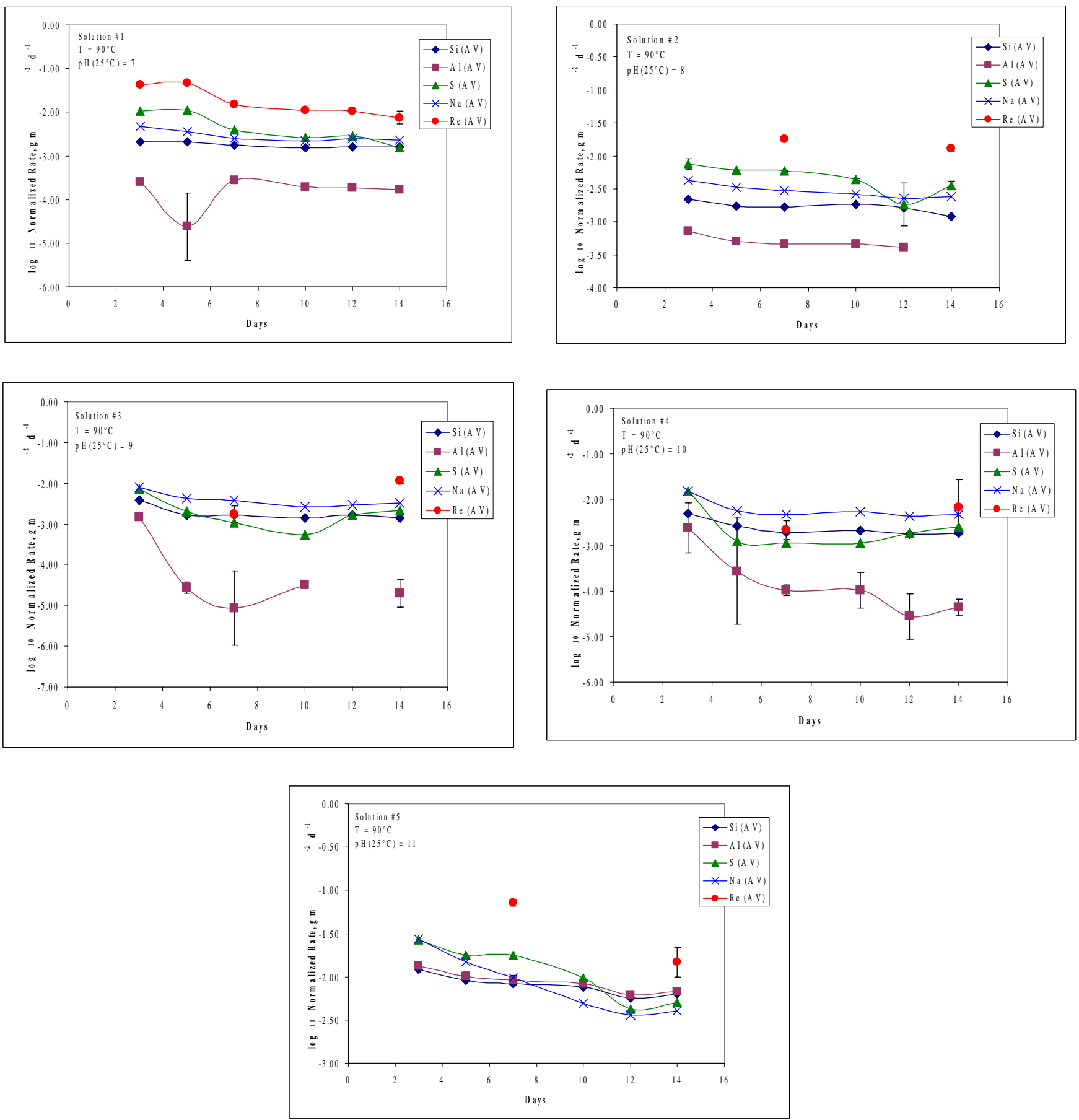

Figure 3-4. Normalized release rate $\left(\log _{10}\right)$ as a function of time and leachant pH for LAW 1123 bed product SPFT experiments at $90^{\circ} \mathrm{C}^{7}$ and $0.2 \mathrm{~mL} / \mathrm{min}$ flow rate. The average of the datasets given in the Appendices are plotted along with the standard deviations for Re and $\mathrm{Al}$, the elements that showed the highest variability in the leachate replicates.

\footnotetext{
${ }^{7}$ No data point for $\mathrm{Al}$ at day 14 in $\mathrm{pH} 8$ and day $12 \mathrm{in} \mathrm{pH} 9$ since the measured concentration in the test cell was less than the concentration in the reference cell.
} 


\subsection{SBW 1173 Bed product testing}

SPFT testing was also performed on SBW 1173 bed product. Tests were only performed at $70^{\circ} \mathrm{C}$ and $90^{\circ} \mathrm{C}$ since previous data showed that maximum release rates would be obtained at the higher temperatures. Detailed results of the SBW 1173 bed product SPFT tests are provided in Appendix B, and the averaged temporal release behaviors of Si, Al, Na, S, and Re are plotted in Figure 4-1 and Figure 4-2 along with the standard deviations for Re and $\mathrm{Al}$, the elements that showed the highest variability in the leachate replicates. The averages and standard deviations for all of the elemental releases are tabulated in Appendix B.

\subsection{DISCUSSION}

The objective of this study was to use the SPFT test to assess the durability of the FBSR Na-Al-Si (NAS) mineralized bed products made with LAW and SBW. The SPFT test is completely water saturated and runs at a high flow rate; therefore, the test does not represent the environment typical of a waste repository, e.g. the SPFT is an accelerated test (McGrail et al. , 2003). Also, use of the SPFT method is strictly only valid for homogeneous, single-phase minerals or waste forms. Because the LAW 1123 and SBW 1173 steam-reforming bed products are multi-phase, the SPFT method will provide an indication of the combined release from each of the phases present. However, since all test conditions were the same for both products, a comparison of the maximum release rates from each product can be made since the SPFT measures the fastest rate of dissolution, the forward rate, under dilute solution conditions. 

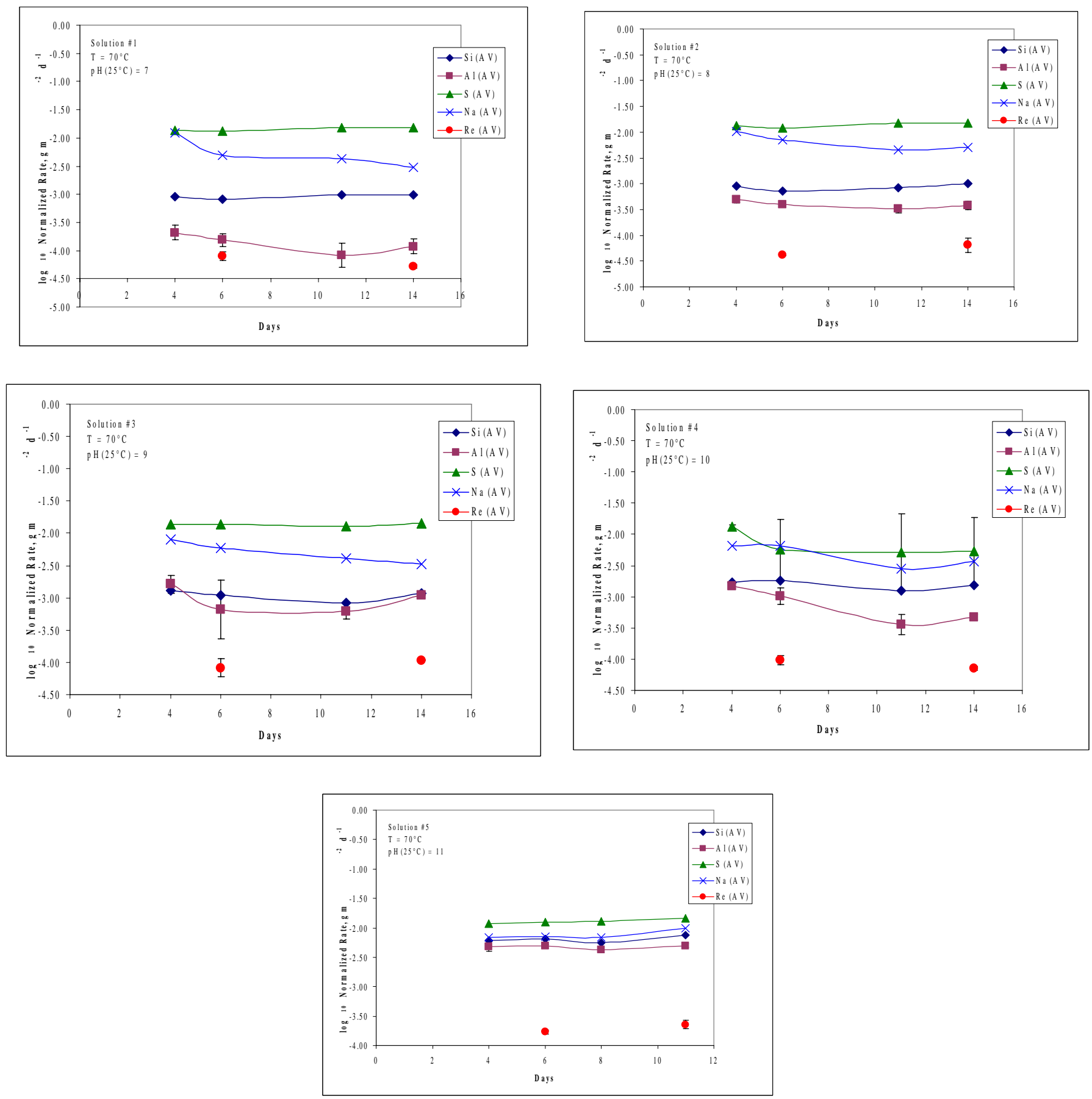

Figure 4-1. Normalized release rate $\left(\log _{10}\right)$ as a function of time and leachant pH for SBW 1173 bed product SPFT experiments at $70^{\circ} \mathrm{C}$ and $0.2 \mathrm{~mL} / \mathrm{min}$ flow rate. The average of the datasets given in the Appendices are plotted along with the standard deviations for $\mathrm{Re}$ and $\mathrm{Al}$, the elements that showed the highest variability in the leachate replicates. 
WSRC-TR-2005-00124

Revision 0
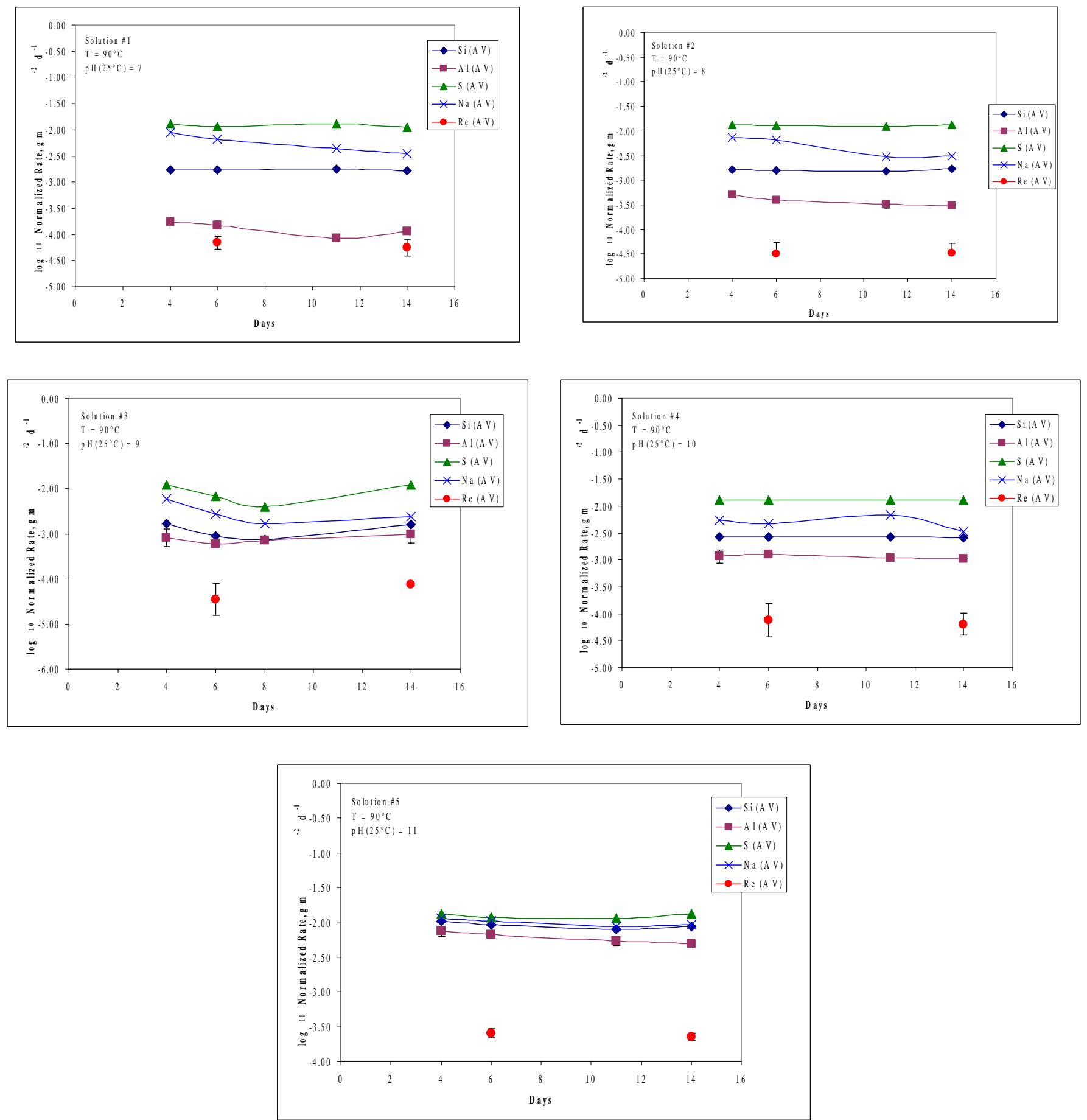

Figure 4-2. Normalized release rate $\left(\log _{10}\right)$ as a function of time and leachant pH for SBW 1173 bed product SPFT experiments at $90^{\circ} \mathrm{C}$ and $0.2 \mathrm{~mL} / \mathrm{min}$ flow rate. The average of the datasets given in the Appendices are plotted along with the standard deviations for Re and $\mathrm{Al}$, the elements that showed the highest variability in the leachate replicates. 


\subsection{Comparison between LAW 1123 and SBW 1173 bed products}

Looking at the plots in Figure 3-1, Figure 3-2, Figure 3-3, and Figure 3-4, the dissolution rates of each monitored element are highly dependent on the temperature and the solution pH. For sample LAW 1123, the release of S tracked fairly well with Re with respect to $\mathrm{pH}$ (see Figure 4-3), and at pH 7, 8 and 11 exhibited faster release rates than the other elements. Faster release rates for rhenium and sulfur were also observed in previous SPFT testing of LAW steam reforming materials (McGrail et al., 2003).

In Figure 4-3, normalized release rate versus leachant $\mathrm{pH}$ is plotted for SPFT experiments of both 1123 (at 7 days) LAW and SBW 1173 (at 6 days - no 7-day data available) in order to further assess the dependence of release rate on $\mathrm{pH}$ and to compare to PCT data reported by Pareizs et al. (2005). For the LAW 1123, the releases of Si and Na tracked very well together. Less Al is released than any other element from the LAW 1123 and the release is a function of $\mathrm{pH}$, which is consistent with the PCT data of Pareizs et al. (2005). It was indicated by Pareizs et al. (2005) that different amounts of $\mathrm{Al}(\mathrm{OH})_{4}{ }^{-}$are present at end-state $\mathrm{pH}$ values in the PCT. For the SBW 1173 bed product, the releases of $\mathrm{Si}, \mathrm{Al}$, and Na tracked together while Re had the lowest release and $S$ had the highest release. As listed in Table 4-1, Xray diffraction (XRD) analyses indicated the presence of unreacted silica and sodium aluminates, e.g. quartz $\left(\mathrm{SiO}_{2}\right)$, beta-alumina $\left(\mathrm{NaAl}_{11} \mathrm{O}_{17}\right)$, and combeite $\left(\mathrm{Na}_{5.27} \mathrm{Ca}_{3}\left(\mathrm{SiO}_{6} \mathrm{O}_{18}\right)\right)$. This would seem to indicate that the SBW 1173 bed product did not completely mineralize to the desired NAS host phases although the S release rate is about the same as that in the LAW 1123 and the Re release rate is lower than the LAW 1123 sample.

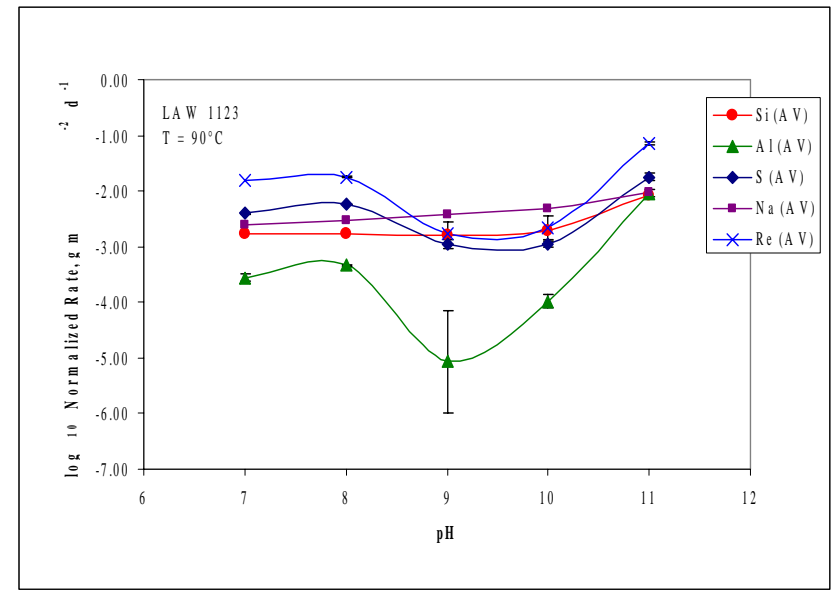

(a)

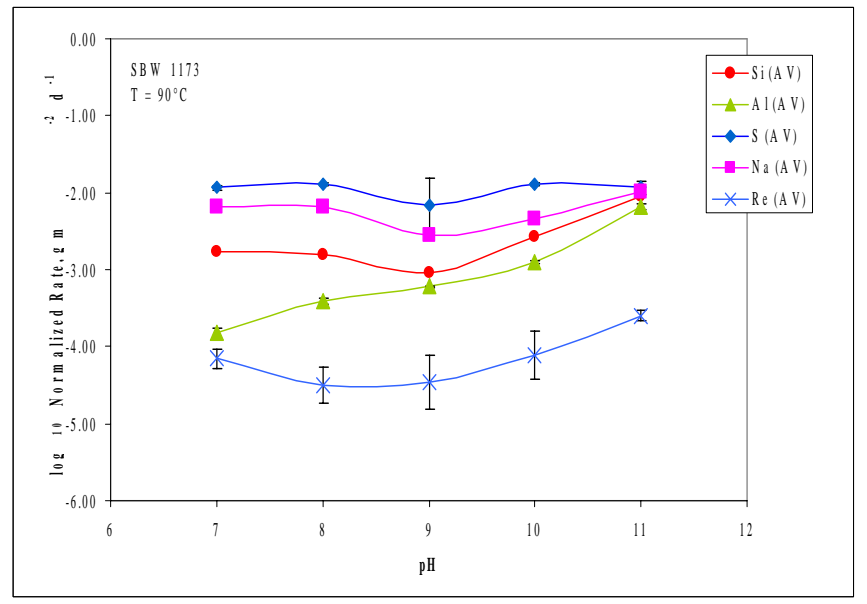

(b)

Figure 4-3. Plots of normalized release rate versus leachant $\mathrm{pH}$ for SPFT experiments - (a) LAW 1123 (7-day mark) and (b) SBW 1173 (6-day mark)

As stated earlier, both samples LAW 1123 and SBW 1173 were subjected to the same test conditions in the SPFT tests. However, since the SBW 1173 bed product was only tested at $70^{\circ} \mathrm{C}$ and $90^{\circ} \mathrm{C}$, a comparison of release rates could only be made at those temperatures. Analyses of Figure 3-3, Figure 3-4, Figure 4-1, and Figure 4-2 indicate that the dissolution rates of each monitored element are highly dependent on the temperature and solution $\mathrm{pH}$ (see also Figure 4-3). At $70^{\circ} \mathrm{C}$, the general trend in elemental release (fastest to slowest) as a function of time is $\mathrm{S}>\mathrm{Na}>\mathrm{Si}>\mathrm{Al}>\mathrm{Re}$ for $\mathrm{SBW} 1173$ (Figure 4-1). At $70^{\circ} \mathrm{C}$ for LAW 1123 the Re release as a function of time is higher than the $S$ and the general trend is $\mathrm{Re}>\mathrm{S}>\mathrm{Na}>\mathrm{Si}>\mathrm{Al}$ at $\mathrm{pH}$ of 7 (solution 1 in Figure 3-3). The overall LAW 1123 Re release is still very slow, e.g. Re release rate is between -2 and $-2.5 \log _{10} R e \mathrm{~g} / \mathrm{m}^{2} \bullet$ day for all the LAW 1123 solutions (Figure 3-3). Also, LAW 1123 exhibited $\mathrm{Na}>\mathrm{Si}=\mathrm{S}>\mathrm{Al}$ in the $\mathrm{pH} 9$ and $\mathrm{pH} 10$ solutions but not in the 
other solutions (pH 7, 8, and 11). In the $\mathrm{pH} 9$ and $\mathrm{pH} 10$ solutions Re release was the lowest of all the solution pH's tested (Figure 3-3).

While the Re release for the LAW and SBW samples was in the -2 to -5 range in terms of $\log _{10} \mathrm{~g} / \mathrm{m}^{2} \bullet$ day, the Re release was significantly slower for sample SBW 1173 than sample LAW 1123 in SPFT testing (13 orders of magnitude - see Figure 4-4). The difference in Re release between the LAW 1123 and SBW 1173 could be due to REDOX effects - LAW 1123 had a REDOX of 0.28 and SBW 1173 had a REDOX of 0.81. Mattigod et al. (in press) made phase-pure perrhenate sodalite $\left[\mathrm{Na}_{8}\left(\mathrm{AlSiO}_{4}\right)_{6}\left(\mathrm{ReO}_{4}\right)_{2}\right]$ that demonstrated that oxidized $\mathrm{Re}^{+7}$ is incorporated in the aluminosilicate cage structure of sodalite. Therefore, in oxidized samples the $\mathrm{Re}^{+7}$ substitutes into the sodalite structure while in reduced bed products where the rhenium may be $\mathrm{Re}^{+4}$ and it will not go into the sodalite cage structure, but it may be present in a separate phase such as insoluble $\mathrm{ReO}_{2}$. This trend was reversed for S release (see Figure 4-4) and $\mathrm{S}$ release appeared less $\mathrm{pH}$ dependent than Re release (Figure 4-4).

As stated above, the release of Re was lower in SBW 1173 and higher in LAW 1123, but the S and Re releases at $90^{\circ} \mathrm{C}$ for the LAW 1123 tracked each other (see Figure 4-5). However, the release of Re and S did not appear related in the SBW 1173 product (see Figure 4-5).

Table 4-1. Mineral phases identified (via XRD) in the tested FBSR bed products

\begin{tabular}{|c|c|c|}
\hline Mineral Phase & Sample LAW 1123 & Sample SBW 1173 \\
\hline $\begin{array}{l}\mathrm{NaAlSiO}_{4} \\
\text { Carnegeite }\end{array}$ & Major & $\overline{---}$ \\
\hline $\begin{array}{l}\left(\mathrm{K}_{0.25} \mathrm{Na}_{0.75}\right) \mathrm{AlSiO}_{4} \\
\text { K-substituted Nepheline }\end{array}$ & --- & Major \\
\hline $\begin{array}{l}\mathrm{Na}_{0.89} \mathrm{Al}_{0.9} \mathrm{Si}_{1.1} \mathrm{O}_{4} \\
\text { Si-rich Nepheline }\end{array}$ & Major & --- \\
\hline $\begin{array}{l}\mathrm{Na}_{6}\left[\mathrm{Al}_{6} \mathrm{Si}_{6} \mathrm{O}_{24}\right]\left(\mathrm{Na}_{2} \mathrm{SO}_{4}\right) \\
\text { Nosean }\end{array}$ & Minor & --- \\
\hline $\begin{array}{l}\mathrm{Na}_{6}\left[\mathrm{Al}_{6} \mathrm{Si}_{6} \mathrm{O}_{24}\right](2 \mathrm{NaCl}) \\
\text { Sodalite }\end{array}$ & --- & Trace \\
\hline $\begin{array}{l}\mathrm{Al}_{2} \mathrm{O}_{3} \text { (from starting bed) } \\
\text { Corundum }\end{array}$ & $\begin{array}{c}-- \\
\end{array}$ & Minor \\
\hline $\begin{array}{l}\mathrm{TiO}_{2} \text { (clay impurity) } \\
\text { Anatase }\end{array}$ & Trace & --- \\
\hline $\begin{array}{l}\mathrm{SiO}_{2} \text { (clay impurity) } \\
\text { Quartz }\end{array}$ & --- & Trace \\
\hline $\begin{array}{l}\mathrm{NaAl}_{11} \mathrm{O}_{17} \\
\text { Beta-Alumina }\end{array}$ & $\begin{array}{c}-- \\
\end{array}$ & Trace \\
\hline $\begin{array}{l}\mathrm{Na}_{5.27} \mathrm{Ca}_{3}\left(\mathrm{SiO}_{6} \mathrm{O}_{18}\right) \\
\text { Combeite }\end{array}$ & --- & Minor \\
\hline
\end{tabular}

--- Not Detected 


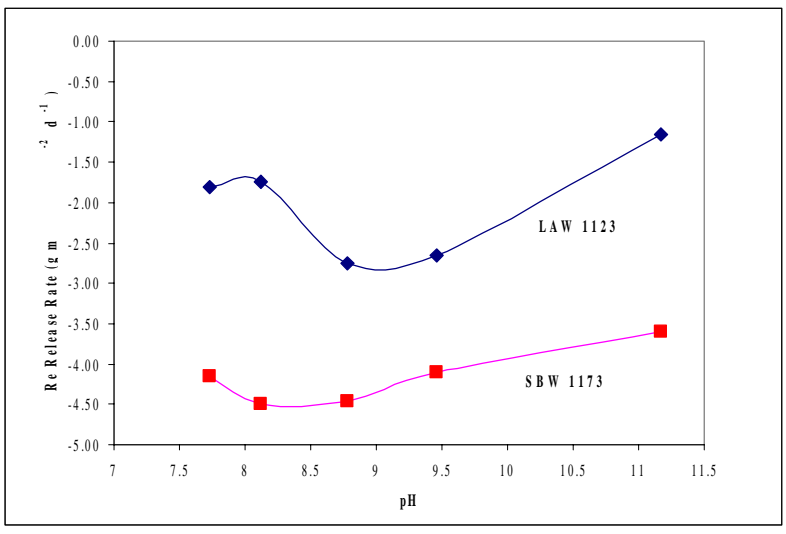

(a) Re release vs. $\mathrm{pH}$

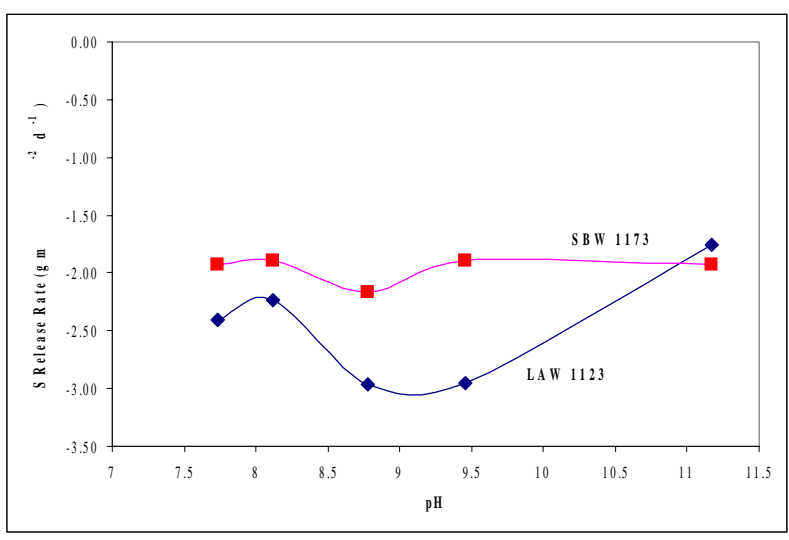

(b) $\mathrm{S}$ release vs. $\mathrm{pH}$

Figure 4-4. Plots of Re and S release versus pH for LAW 1123 and SBW 1173 (SPFT data at $90^{\circ} \mathrm{C}$ )

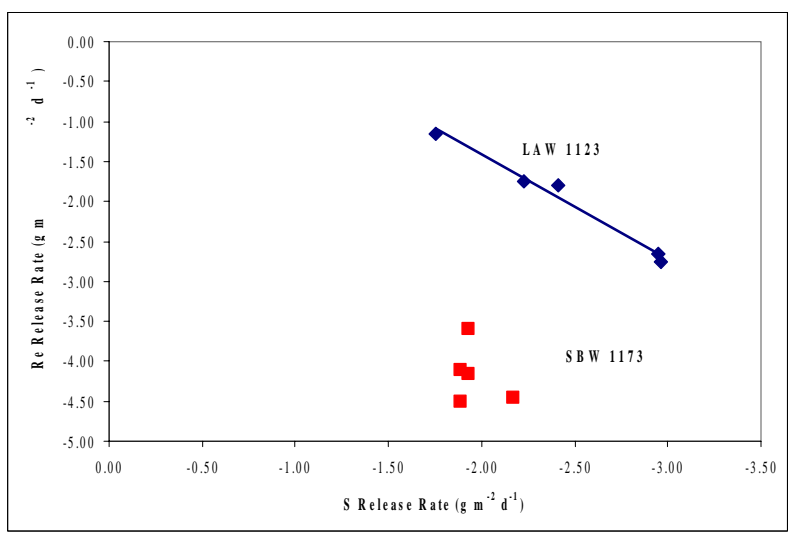

Figure 4-5. Plot of Re versus S release for LAW 1123 and SBW 1173 (SPFT data at $90^{\circ} \mathrm{C}$ )

\subsection{Comparison of FBSR mineral waste forms to borosilicate glass waste forms}

The surface area and surface roughness of the FBSR mineral waste forms studied and a borosilicate glass waste glass are very different. A FBSR mineral waste form has a rougher surface topography and greater porosity than a glass waste form, which has a smoother surface and no/little porosity. McGrail et al. (2003) stated that due to the large difference in BET (measured) surface area versus geometric (calculated) surface area of the FBSR bed product, the normalized release rates of a FBSR mineral waste form could be much slower than those of tested LAW glasses. It was determined that the correct surface area to use for calculating the dissolution rates for glass particles is the geometric surface area (McGrail et al., 1997). Section 2.1.2 indicates that the release rates of the LAW 1123 and SBW 1173 bed products could be more than 200X and 120X lower, respectively, than those of glass when the BET surface area is used rather than the geometric. In SPFT round robin testing conducted at SRNL for ASTM, target flow rates of $2.0 \mathrm{~mL} / \mathrm{min}$ and $0.2 \mathrm{~mL} / \mathrm{min}$ were required for testing the Low-Activity Reference Material (LRM) glass. The $0.2 \mathrm{~mL} / \mathrm{min}$ flow rate was also used for the FBSR waste forms tested in this study and by McGrail et al. (2003) in order to ensure that no back reactions occurred during the SPFT testing. The differences in flow rates have no effect on the results of the SPFT test results as long as the flow is 
sufficient enough to prevent back reactions from occurring. This allowed a direct comparison of data developed by SRNL for glass and FBSR product (Figure 4-6). This comparison demonstrates the relative concentrations of the normalized Si dissolution rate at $90^{\circ} \mathrm{C}$ as a function of test duration for glass (using the glass BET surface area) and the LAW and SBW steam reformer mineral waste forms (using the glass BET surface area) tested in this study. This comparison, on a logarithmic scale, demonstrates that the release from the mineral waste forms is much lower than of the LAW glass standard known as LRM. While this is consistent with the findings of McGrail et. al. (2003) and the Performance Assessment by Mann, et. al (2003). It should be noted that if the fractional release rates are calculated (without the surface area term) then the durability of the glass and mineral waste form are about the same.

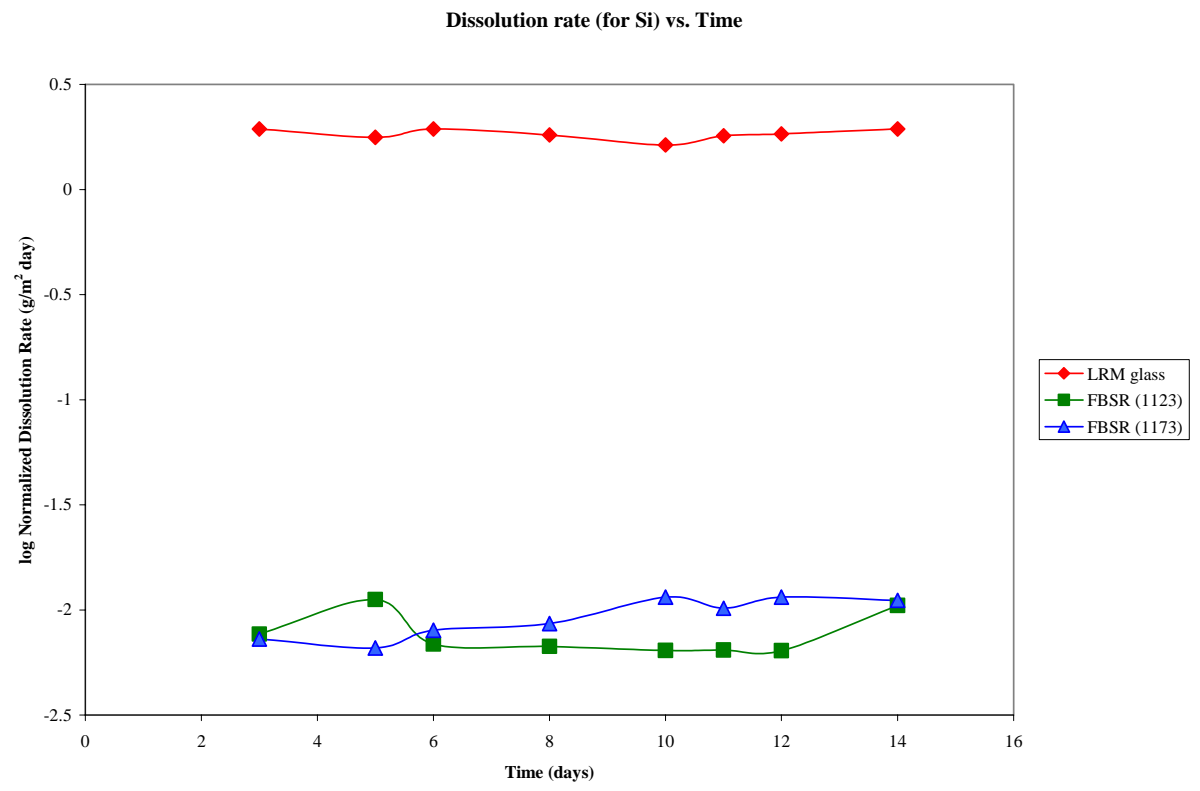

Figure 4-6. Comparison of the dissolution rate of Si for $90^{\circ} \mathrm{C}$ data for glass and FBSR mineral products tested in this study.

\subsection{CONCLUSIONS}

Two samples of FBSR mineral waste form - LAW 1123 and SBW 1173 - were subjected to SPFT testing to provide data for disposal performance assessment (PA) activities. Sample LAW 1123 was tested at $25^{\circ}, 40^{\circ}, 70^{\circ}$, and $90^{\circ} \mathrm{C}$, while SBW 1173 was only tested at $70^{\circ}$ and $90^{\circ} \mathrm{C}$. For tests in which both samples were tested at the same temperatures, the relative release rates (fastest to slowest) were compared. Both samples were found to consist of more than one mineral phase, so the SPFT was a conservative test that provided overall bounding release rates. In the $70^{\circ} \mathrm{C}$ tests, the Re release rate seemed to increase slightly at pH 11 in both samples LAW 1123 and SBW 1173, but the overall Re release rate was lower in SBW 1173 than LAW 1123. The release of S though was essentially the same for both samples. In the tests at $90^{\circ} \mathrm{C}$, the overall release rate of Re from sample SBW 1173 was less than that in sample LAW 1123. For S, the overall release rates were approximately the same for LAW 1123 and SBW 1173 and very constant over the 14-day test duration.

This study confirmed the work of McGrail et al. (2003) that BET surface area should be used rather than geometric surface area when measuring FBSR waste form releases. The measured, BET method more 
accurately determines the surface area of FBSR product due to the more porous and irregular surface of the material. The surface of a glass waste form is much more regular and the calculated geometric surface area is typically used for determining dissolution behavior.

\subsection{RECOMMENDATIONS/PATH FORWARD}

From SPFT tests performed on a LAW FBSR mineral waste form by McGrail et al. (2003), it was stated that by assuming similar activation energy for the dissolution kinetics of FBSR silicate mineral phases to the activation energy used for borosilicate glass dissolution, the FBSR product performance appeared to be approximately equivalent to LAW glass. Initial indications from the McGrail et al. (2003) study show that the FBSR product could be an alternative waste form for high sodium-containing wastes compared to glass waste forms. However, FBSR product has not been as extensively tested as waste glasses. Further testing should include:

- More durability testing of all FBSR products (LAW and SBW) using both the SPFT and PCT methods to compare to various glasses, e.g., release rate comparisons on both a normalized and fractional release basis and to support further PA activities.

- Re values were above detection limits in this study, but the levels were close enough to the analytic detection limit of ICP-MS to allow for analytical inconsistencies. Feed materials should be spiked with higher concentrations of Re in future FBSR testing to eliminate these analytic difficulties.

- Determination of the preferred host mineral phase for Re and S under oxidizing and reducing conditions to determine which minimizes release of these elements during SPFT testing.

- $\quad$ SPFT and PCT testing of phase-pure Re and S sodalites and nosean to determine the retention of these species in the host sodalite/nosean phases independent of the remaining NAS phases in the FBSR product.

- Spiking feed materials with excess Cs and I in future FBSR tests to allow these elements to be analyzed for in the leachates.

\subsection{ACKNOWLEDGEMENTS}

The authors would like to thank the Department of Energy Office of Environmental Management (DOEEM) for funding this study. They would also to thank laboratory technicians Vickie Williams, Tony Burckhalter, Phyllis Workman, and Irene Reamer for their assistance in performing the SPFT tests, and to personnel in the Analytical Development Section (ADS) and the Mobile Lab (ML) for numerous sample analyses. Finally, appreciation goes to Jim Marra and David Peeler for reviews of this report. 


\subsection{REFERENCES}

American Society for Testing and Materials. Standard Practice for Measurement of the Glass Dissolution Rate Using the Single-Pass Flow-Through Test Method (DRAFT).

Brantley, S.L. and N.P. Mellott. 2000. "Surface area and porosity of primary silicate minerals." American Mineralogist 85:1767-1783.

Brunauer, S., P.H. Emmett, and E. Teller. 1938. “Adsorption of gases in multimolecular layers.” Journal of Physical Chemistry 60:309-319.

Bullock, Jr., J.H, J.D. Cathcart, and W.J. Betterton. 2002. Analytical methods utilized by the United States Geological Survey for the analysis of coal and coal combustion by-products; US Geological Survey: Denver, CO.

Helgeson, H.C., W.M. Murphy, and P. Aagard. 1984. "Thermodynamic and kinetic constraints on reaction rates among minerals and aqueous solutions II. Rate constants, effective surface area, and the hydrolysis of feldspar.” Geochimica et Cosmochimica Acta 48:2405-2432.

Mann, F.M., Puigh, R.J., Khaleel, R., Finfrock, S., McGrail, B.P., Bacon, D.H., Serne, R.J., "Risk Assessment Supporting the Decision on the Initial Selection of Supplemental ILAW Technologies,” RPP17675, Rev. 0 (September 2003).

Mattigod, S.V., B.P. McGrail, D.E. McCready, L.Q. Wang, K.E. Parker, and J.S. Young. (in press). "Synthesis and Structure of Perrhenate Sodalite."

McGrail, B.P., W.L. Ebert, A.J. Bakel, and D.K. Peeler. 1997. "Measurement of kinetic rate law parameters on a Na-Ca-Al borosilicate glass for low-activity waste.” Journal of Nuclear Materials 249:175-189.

McGrail, B.P., H.T. Schaef, P.F. Martin, D.H. Bacon, E.A. Rodriguez, D.E. McCready, and A.R. Primak. 2003. Initial suitability evaluation of steam-reformed low activity waste for direct land disposal. PNWD-3234, Bechtel National, Inc., Richland, Washington.

Olson, A.L., N.R. Soelberg, D.W. Marshall, and G.L. Anderson. 2004a. Fluidized Bed Steam Reforming of Hanford LAW Using THOR ${ }^{S M}$ Mineralizing Technology, INEEL/EXT-04-02492, November.

Olson, A.L., N.R. Soelberg, D.W. Marshall, and G.L. Anderson. 2004b. Fluidized Bed Steam Reforming of INEEL SBW Using THOR ${ }^{S M}$ Mineralizing Technology, INEEL/EXT-04-02564, December.

Pareizs, J.M., C.M. Jantzen, and T.H. Lorier. 2005. Durability testing of fluidized bed steam reformer (FBSR) waste forms for high sodium wastes at Hanford and Idaho, WSRC-TR-200500102, Savannah River Site, Aiken, SC 29808. 


\section{APPENDIX A. SPFT TEST DATA OF LAW 1123 BED PRODUCT}

Table A1. Experimental conditions and SPFT data for tests with LAW 1123 bed product (all tests performed at 0.2 mL/min flow rate)

\begin{tabular}{|c|c|c|c|c|c|c|c|c|c|c|c|c|c|}
\hline $\begin{array}{c}\text { Sample } \\
\text { ID }\end{array}$ & $\begin{array}{c}\text { Day } \\
\text { sampled }\end{array}$ & $\begin{array}{c}\text { Temp } \\
\left({ }^{\circ} \mathrm{C}\right)\end{array}$ & $\mathrm{pH}$ & $\begin{array}{c}\mathrm{C}_{\mathrm{Si}} \\
\mathrm{mg} \mathrm{L}^{-1}\end{array}$ & $\begin{array}{c}\mathrm{C}_{\mathrm{Al}} \\
\mathrm{mg} \mathrm{L}^{-1}\end{array}$ & $\begin{array}{c}\mathrm{C}_{\mathrm{S}} \\
\mathrm{mg} \mathrm{L}^{-1}\end{array}$ & $\begin{array}{c}\mathrm{C}_{\mathrm{Na}} \\
\mathrm{mg} \mathrm{L}^{-1}\end{array}$ & $\begin{array}{c}\mathrm{C}_{\mathrm{Re}} \\
\mu g \mathrm{~L}^{-1}\end{array}$ & $\begin{array}{l}\text { Rate Si } \\
\mathrm{g} \mathrm{m}^{-2} \mathrm{~d}^{-1}\end{array}$ & $\begin{array}{l}\text { Rate Al } \\
\mathrm{g} \mathrm{m}^{-2} \mathrm{~d}^{-1}\end{array}$ & $\begin{array}{c}\text { Rate S } \\
\mathrm{g} \mathrm{m}^{-2} \mathrm{~d}^{-1}\end{array}$ & $\begin{array}{l}\text { Rate Na } \\
\mathrm{g} \mathrm{m}^{-2} \mathrm{~d}^{-1}\end{array}$ & $\begin{array}{l}\text { Rate Re } \\
\mathrm{g} \mathrm{m}^{-2} \mathrm{~d}^{-1}\end{array}$ \\
\hline \multicolumn{14}{|c|}{$25^{\circ} \mathrm{C}$ and $40^{\circ} \mathrm{C}$ tests } \\
\hline \multicolumn{14}{|c|}{ Cell L19-target $p H 7$} \\
\hline L19-2-1 & 3 & 25.8 & 7.67 & 0.01 & na & 1.049 & 8.53 & na & $9.66 \mathrm{E}-05$ & $6.25 \mathrm{E}-05$ & 2.39E-02 & 3.14E-03 & na \\
\hline L19-2-2 & 6 & 25.7 & 7.7 & na & na & na & na & na & na & na & na & na & na \\
\hline L19-2-3 & 8 & 25.7 & 7.59 & 0.326 & 0.122 & 0.05 & 2.35 & 1.09 & $1.05 \mathrm{E}-04$ & 2.89E-05 & $1.14 \mathrm{E}-03$ & 8.54E-04 & $1.44 \mathrm{E}-03$ \\
\hline L19-2-4 & 10 & 25.7 & 7.72 & na & na & na & na & na & na & na & na & na & na \\
\hline L19-2-5 & 13 & 25.6 & 7.63 & 0.204 & 0.096 & 0.05 & 1.23 & na & 6.33E-05 & 2.19E-05 & $1.12 \mathrm{E}-03$ & 4.28E-04 & na \\
\hline L19-2-6 & 14 & 25.7 & 7.67 & 0.637 & 0.137 & 0.05 & 2.33 & 1.18 & $2.04 \mathrm{E}-04$ & $2.62 E-05$ & $1.11 \mathrm{E}-03$ & 7.66E-04 & 1.52E-03 \\
\hline \multicolumn{14}{|c|}{ Cell L14-target $p H 7$} \\
\hline L14-2-1 & 3 & 25.8 & 7.67 & 0.266 & 0.303 & 1.62 & 12.1 & na & 8.57E-05 & 8.87E-05 & 3.71E-02 & 4.49E-03 & na \\
\hline L14-2-2 & 6 & 25.7 & 7.7 & na & na & na & na & na & na & na & na & na & na \\
\hline L14-2-3 & 8 & 25.7 & 7.59 & 0.45 & 0.119 & 0.05 & 1.89 & 1.06 & $1.51 \mathrm{E}-04$ & 2.87E-05 & 1.18E-03 & 7.04E-04 & $1.45 \mathrm{E}-03$ \\
\hline L14-2-4 & 10 & 25.7 & 7.72 & na & na & na & na & na & na & na & na & na & na \\
\hline L14-2-5 & 13 & 25.6 & 7.63 & 0.327 & 0.103 & 0.05 & 1.41 & na & $1.15 \mathrm{E}-04$ & 2.67E-05 & $1.24 \mathrm{E}-03$ & 5.48E-04 & na \\
\hline L14-2-6 & 14 & 25.7 & 7.67 & 0.293 & 0.092 & 0.05 & 1.52 & 0.44 & 7.37E-05 & $9.61 \mathrm{E}-06$ & 8.90E-04 & 3.79E-04 & 4.39E-04 \\
\hline \multicolumn{14}{|c|}{ Cell L18-target $p H 8$} \\
\hline L18-2-1 & 3 & 25.8 & 7.94 & 0.351 & 0.334 & 0.05 & 3.35 & na & $1.22 \mathrm{E}-04$ & $1.14 \mathrm{E}-04$ & $1.28 \mathrm{E}-03$ & $1.12 \mathrm{E}-03$ & na \\
\hline L18-2-2 & 6 & 25.7 & 7.9 & na & na & na & na & na & na & na & na & na & na \\
\hline L18-2-3 & 8 & 25.7 & 7.89 & 0.333 & 0.341 & 0.05 & 1.62 & 0.65 & $1.05 \mathrm{E}-04$ & 9.83E-05 & $1.09 \mathrm{E}-03$ & $1.77 \mathrm{E}-04$ & 8.05E-04 \\
\hline L18-2-4 & 10 & 25.7 & 8.06 & na & na & na & na & na & na & na & na & na & na \\
\hline L18-2-5 & 13 & 25.6 & 7.98 & 0.299 & 0.264 & 0.05 & 2.1 & na & 8.95E-05 & 8.35E-05 & $1.20 \mathrm{E}-03$ & 4.39E-04 & na \\
\hline L18-2-6 & 14 & 25.7 & 8.02 & 0.291 & 0.299 & 0.05 & 2.07 & 0.35 & $1.01 \mathrm{E}-04$ & 8.06E-05 & $1.20 \mathrm{E}-03$ & 6.37E-04 & 4.62E-04 \\
\hline \multicolumn{14}{|c|}{ Cell L26-target $p H 8$} \\
\hline L26-2-1 & 3 & 25.8 & 7.96 & 0.131 & 0.352 & 0.05 & 2.94 & na & $3.48 \mathrm{E}-05$ & $9.27 \mathrm{E}-05$ & $9.84 \mathrm{E}-04$ & 7.30E-04 & na \\
\hline L26-2-2 & 6 & 25.7 & 7.85 & na & na & na & na & na & na & na & na & na & na \\
\hline L26-2-3 & 8 & 25.7 & 7.92 & 0.057 & 0.277 & 0.05 & 1.66 & 0.62 & $1.44 \mathrm{E}-05$ & 7.56E-05 & $1.04 \mathrm{E}-03$ & 1.83E-04 & 7.37E-04 \\
\hline L26-2-4 & 10 & 25.7 & 8.06 & na & na & na & na & na & na & na & na & na & na \\
\hline L26-2-5 & 13 & 25.6 & 7.93 & 0.023 & 0.265 & 0.05 & 0.905 & na & 4.16E-06 & 7.62E-05 & 1.09E-03 & na & na \\
\hline L26-2-6 & 14 & 25.7 & 8.03 & 0.01 & 0.217 & 0.05 & 1.97 & 0.34 & na & $4.80 \mathrm{E}-05$ & $1.09 \mathrm{E}-03$ & $5.44 \mathrm{E}-04$ & $4.08 \mathrm{E}-04$ \\
\hline
\end{tabular}


WSRC-TR-2005-00124

Revision 0

\begin{tabular}{|c|c|c|c|c|c|c|c|c|c|c|c|c|c|}
\hline $\begin{array}{c}\text { Sample } \\
\text { ID }\end{array}$ & $\begin{array}{c}\text { Day } \\
\text { sampled }\end{array}$ & $\begin{array}{c}\text { Temp } \\
\left({ }^{\circ} \mathrm{C}\right)\end{array}$ & $\mathrm{pH}$ & $\begin{array}{c}\mathrm{C}_{\mathrm{Si}} \\
\mathrm{mg} \mathrm{L}^{-1}\end{array}$ & $\begin{array}{c}\mathrm{C}_{\mathrm{Al}} \\
\mathrm{mg} \mathrm{L}^{-1}\end{array}$ & $\begin{array}{c}\mathrm{C}_{\mathrm{S}} \\
\mathrm{mg} \mathrm{L}^{-1}\end{array}$ & $\begin{array}{c}\mathrm{C}_{\mathrm{Na}} \\
\mathrm{mg} \mathrm{L}^{-1}\end{array}$ & $\begin{array}{c}\mathrm{C}_{\mathrm{Re}} \\
\mu \mathrm{g} \mathrm{L}^{-1}\end{array}$ & $\begin{array}{l}\text { Rate Si } \\
\mathrm{g} \mathrm{m}^{-2} \mathrm{~d}^{-1}\end{array}$ & $\begin{array}{l}\text { Rate Al } \\
\mathrm{g} \mathrm{m}^{-2} \mathrm{~d}^{-1}\end{array}$ & $\begin{array}{c}\text { Rate S } \\
\mathrm{g} \mathrm{m}^{-2} \mathrm{~d}^{-1}\end{array}$ & $\begin{array}{l}\text { Rate Na } \\
\mathrm{g} \mathrm{m}^{-2} \mathrm{~d}^{-1}\end{array}$ & $\begin{array}{l}\text { Rate Re } \\
\mathrm{g} \mathrm{m}^{-2} \mathrm{~d}^{-1}\end{array}$ \\
\hline \multicolumn{14}{|c|}{ Cell L09-target $p H 9$} \\
\hline L09-2-1 & 3 & 25.8 & 8.7 & 0.456 & 0.087 & 0.125 & 4.06 & na & $1.41 \mathrm{E}-04$ & $2.02 E-05$ & 2.70E-03 & $1.41 \mathrm{E}-03$ & na \\
\hline L09-2-2 & 6 & 25.7 & 8.66 & na & na & na & na & na & na & na & na & na & na \\
\hline L09-2-3 & 8 & 25.7 & 8.67 & 0.4 & 0.095 & 0.05 & 2.8 & 0.17 & $1.28 \mathrm{E}-04$ & 2.30E-05 & 1.13E-03 & 6.63E-04 & 1.94E-04 \\
\hline L09-2-4 & 10 & 25.7 & 8.84 & na & na & na & na & na & na & na & na & na & na \\
\hline L09-2-5 & 13 & 25.6 & 8.74 & 0.736 & 0.105 & 0.05 & 1.31 & na & $2.48 \mathrm{E}-04$ & 2.79E-05 & 1.17E-03 & 4.79E-04 & na \\
\hline L09-2-6 & 14 & 25.7 & 8.77 & 0.854 & 0.055 & 0.05 & 4.49 & 0.09 & $2.78 \mathrm{E}-04$ & 1.31E-05 & 1.13E-03 & 1.43E-03 & 8.69E-05 \\
\hline \multicolumn{14}{|c|}{ Cell L29-target $p H 9$} \\
\hline L29-2-1 & 3 & 25.8 & 8.66 & 0.01 & 0.075 & 0.78 & 5.22 & na & na & 1.87E-05 & $1.91 \mathrm{E}-02$ & 2.06E-03 & na \\
\hline L29-2-2 & 6 & 25.7 & 8.66 & na & na & na & na & na & na & na & na & na & na \\
\hline L29-2-3 & 8 & 25.7 & 8.67 & 0.152 & 0.137 & 0.05 & 2.48 & 0.16 & 4.84E-05 & 3.77E-05 & 1.17E-03 & 5.65E-04 & 1.87E-04 \\
\hline L29-2-4 & 10 & 25.7 & 8.85 & na & na & na & na & na & na & na & na & na & na \\
\hline L29-2-5 & 13 & 25.6 & 8.71 & 0.01 & 0.142 & 0.05 & 0.417 & na & na & 4.19E-05 & $1.22 \mathrm{E}-03$ & $1.46 \mathrm{E}-04$ & na \\
\hline L29-2-6 & 14 & 25.7 & 8.79 & 0.437 & 0.154 & 0.05 & 1.34 & 0.16 & $1.56 \mathrm{E}-04$ & 4.97E-05 & $1.25 \mathrm{E}-03$ & 3.04E-04 & 2.00E-04 \\
\hline \multicolumn{14}{|c|}{ Cell L25-target $p H 10$} \\
\hline L25-2-1 & 3 & 25.8 & 9.42 & 0.189 & 0.045 & 0.163 & 6.31 & na & 5.32E-05 & 6.64E-06 & 3.32E-03 & $1.95 \mathrm{E}-03$ & na \\
\hline L25-2-2 & 6 & 25.7 & 9.3 & na & na & na & na & na & na & na & na & na & na \\
\hline L25-2-3 & 8 & 25.7 & 9.42 & 0.188 & 0.184 & 0.05 & 1.48 & 0.19 & 5.88E-05 & 5.29E-05 & 1.13E-03 & 5.26E-04 & 2.21E-04 \\
\hline L25-2-4 & 10 & 25.7 & 9.61 & na & na & na & na & na & na & na & na & na & na \\
\hline L25-2-5 & 13 & 25.6 & 9.45 & 0.01 & 0.409 & 0.05 & 1.01 & na & 6.03E-05 & $1.26 \mathrm{E}-04$ & $1.14 \mathrm{E}-03$ & 3.58E-04 & na \\
\hline L25-2-6 & 14 & 25.7 & 9.43 & 0.01 & 0.124 & 0.05 & 2.09 & 0.25 & 5.83E-05 & 3.29E-05 & $1.11 \mathrm{E}-03$ & 7.39E-04 & 2.97E-04 \\
\hline \multicolumn{14}{|c|}{ Cell L22-target $p H 10$} \\
\hline L22-2-1 & 3 & 25.8 & 9.51 & 1.04 & 0.184 & 0.582 & 10.2 & na & 3.61E-04 & $5.52 \mathrm{E}-05$ & $1.40 \mathrm{E}-02$ & 3.81E-03 & na \\
\hline L22-2-2 & 6 & 25.7 & 9.36 & na & na & na & na & na & na & na & na & na & na \\
\hline L22-2-3 & 8 & 25.7 & 9.4 & 0.366 & 0.277 & 0.05 & 1.11 & 0.19 & $1.30 \mathrm{E}-04$ & $9.15 \mathrm{E}-05$ & $1.25 \mathrm{E}-03$ & 4.31E-04 & 2.45E-04 \\
\hline L22-2-4 & 10 & 25.7 & 9.59 & na & na & na & na & na & na & na & na & na & na \\
\hline L22-2-5 & 13 & 25.6 & 9.28 & 0.255 & 0.121 & 0.05 & 1.27 & na & 7.88E-05 & $3.16 \mathrm{E}-05$ & $1.10 \mathrm{E}-03$ & 4.37E-04 & na \\
\hline L22-2-6 & 14 & 25.7 & 9.47 & 0.341 & 0.348 & 0.05 & 0.776 & 0.05 & $1.43 \mathrm{E}-04$ & $1.38 \mathrm{E}-04$ & $1.48 \mathrm{E}-03$ & 3.49E-04 & 4.39E-05 \\
\hline \multicolumn{14}{|c|}{ Cell L15-target $p H 11$} \\
\hline L15-2-1 & 3 & 25.8 & 11.29 & 3.72 & 5.01 & 0.463 & 12.9 & na & $1.32 \mathrm{E}-03$ & 1.73E-03 & 1.13E-02 & 4.84E-03 & na \\
\hline L15-2-2 & 6 & 25.7 & 11.23 & na & na & na & na & na & na & na & na & na & na \\
\hline L15-2-3 & 8 & 25.7 & 11.26 & 3.38 & 4.23 & 0.16 & 6.28 & 9.01 & $1.02 \mathrm{E}-03$ & $1.20 \mathrm{E}-03$ & 3.33E-03 & $1.51 \mathrm{E}-03$ & 1.11E-02 \\
\hline L15-2-4 & 10 & 25.7 & 11.42 & na & na & na & na & na & na & na & na & na & na \\
\hline L15-2-5 & 13 & 25.6 & 11.18 & 2.51 & 3.24 & 0.132 & 5.16 & na & $9.45 \mathrm{E}-04$ & 1.18E-03 & 3.41E-03 & 1.50E-03 & na \\
\hline
\end{tabular}


WSRC-TR-2005-00124

Revision 0

\begin{tabular}{|c|c|c|c|c|c|c|c|c|c|c|c|c|c|}
\hline $\begin{array}{c}\text { Sample } \\
\text { ID }\end{array}$ & $\begin{array}{c}\text { Day } \\
\text { sampled }\end{array}$ & $\begin{array}{c}\text { Temp } \\
\left({ }^{\circ} \mathrm{C}\right)\end{array}$ & $\mathrm{pH}$ & $\begin{array}{c}\mathrm{C}_{\mathrm{Si}} \\
\mathrm{mg} \mathrm{L}^{-1}\end{array}$ & $\begin{array}{c}\mathrm{C}_{\mathrm{Al}} \\
\mathrm{mg} \mathrm{L}^{-1}\end{array}$ & $\begin{array}{c}\mathrm{C}_{\mathrm{S}} \\
\mathrm{mg} \mathrm{L}^{-1}\end{array}$ & $\begin{array}{c}\mathrm{C}_{\mathrm{Na}} \\
\mathrm{mg} \mathrm{L}^{-1}\end{array}$ & $\begin{array}{c}\mathrm{C}_{\mathrm{Re}} \\
\mu \mathrm{g} \mathrm{L^{-1 }}\end{array}$ & $\begin{array}{l}\text { Rate Si } \\
\mathrm{g} \mathrm{m}^{-2} \mathrm{~d}^{-1}\end{array}$ & $\begin{array}{l}\text { Rate Al } \\
\mathrm{g} \mathrm{m}^{-2} \mathrm{~d}^{-1}\end{array}$ & $\begin{array}{c}\text { Rate } \mathrm{S} \\
\mathrm{g} \mathrm{m}^{-2} \mathrm{~d}^{-1}\end{array}$ & $\begin{array}{l}\text { Rate Na } \\
\mathrm{g} \mathrm{m}^{-2} \mathrm{~d}^{-1}\end{array}$ & $\begin{array}{l}\text { Rate Re } \\
\mathrm{g} \mathrm{m}^{-2} \mathrm{~d}^{-1}\end{array}$ \\
\hline L15-2-6 & 14 & 25.7 & 11.25 & 2.17 & 2.82 & 0.111 & 4.67 & 8.55 & 8.24E-04 & $1.04 \mathrm{E}-03$ & 2.90E-03 & 1.93E-03 & $1.32 \mathrm{E}-02$ \\
\hline \multicolumn{14}{|c|}{ Cell L36-target $p H 11$} \\
\hline L36-2-1 & 3 & 25.8 & 11.24 & 0.92 & 2.07 & 0.594 & 7.33 & na & 2.95E-04 & $6.46 \mathrm{E}-04$ & 1.32E-02 & 2.38E-03 & na \\
\hline L36-2-2 & 6 & 25.7 & 11.19 & na & na & na & na & na & na & na & na & na & na \\
\hline L36-2-3 & 8 & 25.7 & 11.22 & 0.643 & 1.61 & 0.198 & 4.64 & 1.37 & 2.04E-04 & 4.48E-04 & 4.36E-03 & $1.01 \mathrm{E}-03$ & $1.76 \mathrm{E}-03$ \\
\hline L36-2-4 & 10 & 25.7 & 11.4 & na & na & na & na & na & na & na & na & na & na \\
\hline L36-2-5 & 13 & 25.6 & 11.11 & 1.37 & 2.38 & 0.05 & 4.91 & na & 4.56E-04 & 7.69E-04 & 1.15E-03 & $1.24 \mathrm{E}-03$ & na \\
\hline L36-2-6 & 14 & 25.7 & 11.19 & 0.838 & 1.75 & 0.05 & 2.95 & 0.93 & 2.73E-04 & 5.51E-04 & 1.13E-03 & 1.03E-03 & $1.21 \mathrm{E}-03$ \\
\hline \multicolumn{14}{|c|}{ Cell L10-target $p H 7$} \\
\hline L10-2-1 & 3 & 41.2 & 7.27 & 0.548 & 0.196 & 0.05 & 3.51 & na & $1.84 \mathrm{E}-04$ & na & 1.17E-03 & $1.32 \mathrm{E}-03$ & na \\
\hline L10-2-2 & 6 & 41 & 7.51 & na & na & na & na & na & na & na & na & na & na \\
\hline L10-2-3 & 8 & 40.9 & 7.37 & 0.55 & 0.175 & 0.05 & 5.26 & 0.7 & 1.81E-04 & 4.63E-05 & 1.15E-03 & 1.95E-03 & $9.21 \mathrm{E}-04$ \\
\hline L10-2-4 & 10 & 40.7 & 7.56 & na & na & na & na & na & na & na & na & na & na \\
\hline L10-2-5 & 13 & 40.5 & 7.41 & 0.387 & 0.144 & 0.05 & 1.48 & na & 1.32E-04 & 3.97E-05 & 1.19E-03 & 5.56E-04 & na \\
\hline L10-2-6 & 14 & 40.5 & 7.45 & 0.365 & 0.176 & 0.05 & 1.17 & 0.55 & $1.21 \mathrm{E}-04$ & 4.04E-05 & 1.17E-03 & 3.64E-04 & 7.27E-04 \\
\hline \multicolumn{14}{|c|}{ Cell L30-target $p H 7$} \\
\hline L30-2-1 & 3 & 41.2 & 7 & 0.672 & 0.21 & 0.05 & 3.94 & na & 1.91E-04 & 5.03E-05 & $9.84 \mathrm{E}-04$ & $1.25 \mathrm{E}-03$ & na \\
\hline L30-2-2 & 6 & 41 & 7.41 & na & na & na & na & na & na & na & na & na & na \\
\hline L30-2-3 & 8 & 40.9 & 7.33 & 0.481 & 0.184 & 0.05 & 2.23 & 0.98 & 1.60E-04 & 4.98E-05 & 1.16E-03 & 8.24E-04 & $1.32 \mathrm{E}-03$ \\
\hline L30-2-4 & 10 & 40.7 & 7.58 & na & na & na & na & na & na & na & na & na & na \\
\hline L30-2-5 & 13 & 40.5 & 7.28 & 0.344 & 0.177 & 0.05 & 1.78 & na & 1.16E-04 & 5.07E-05 & 1.19E-03 & 6.69E-04 & na \\
\hline L30-2-6 & 14 & 40.5 & 7.35 & 0.268 & 0.179 & 0.05 & 1.68 & 0.94 & $8.54 \mathrm{E}-05$ & 4.02E-05 & 1.13E-03 & $5.41 \mathrm{E}-04$ & $1.23 \mathrm{E}-03$ \\
\hline \multicolumn{14}{|c|}{ Cell L21 - target $p H 8$} \\
\hline L21-2-1 & 3 & 41.2 & 7.59 & 0.572 & 0.503 & 0.05 & 3.4 & na & 1.83E-04 & 1.53E-04 & 1.11E-03 & 9.91E-04 & na \\
\hline L21-2-2 & 6 & 41 & 7.77 & na & na & na & na & na & na & na & na & na & na \\
\hline L21-2-3 & 8 & 40.9 & 7.73 & 0.487 & 0.425 & 0.05 & 2.01 & 0.66 & 1.69E-04 & 1.38E-04 & $1.21 \mathrm{E}-03$ & 3.50E-04 & $9.12 \mathrm{E}-04$ \\
\hline L21-2-4 & 10 & 40.7 & 7.92 & na & na & na & na & na & na & na & na & na & na \\
\hline L21-2-5 & 13 & 40.5 & 7.77 & 0.735 & 0.498 & 0.05 & 1.86 & na & 1.35E-04 & 8.64E-05 & 6.37E-04 & $1.82 \mathrm{E}-04$ & na \\
\hline L21-2-6 & 14 & 40.5 & 7.8 & 0.59 & 0.47 & 0.05 & 1.68 & 0.67 & 1.96E-04 & 1.34E-04 & 1.16E-03 & 4.69E-04 & 8.86E-04 \\
\hline \multicolumn{14}{|c|}{ Cell L24-target $p H 8$} \\
\hline L24-2-1 & 3 & 41.2 & 7.34 & 1.26 & 0.917 & 0.05 & 5.25 & na & 4.09E-04 & 2.85E-04 & $1.12 \mathrm{E}-03$ & $1.67 \mathrm{E}-03$ & na \\
\hline L24-2-2 & 6 & 41 & 7.82 & na & na & na & na & na & na & na & na & na & na \\
\hline L24-2-3 & 8 & 40.9 & 7.71 & 1.02 & 0.625 & 0.05 & 3.48 & 0.60 & 3.54E-04 & 2.05E-04 & 1.20E-03 & $9.21 \mathrm{E}-04$ & 8.19E-04 \\
\hline L24-2-4 & 10 & 40.7 & 7.87 & na & na & na & na & na & na & na & na & na & na \\
\hline
\end{tabular}


WSRC-TR-2005-00124

Revision 0

\begin{tabular}{|c|c|c|c|c|c|c|c|c|c|c|c|c|c|}
\hline $\begin{array}{l}\text { Sample } \\
\text { ID }\end{array}$ & $\begin{array}{c}\text { Day } \\
\text { sampled }\end{array}$ & $\begin{array}{c}\text { Temp } \\
\left({ }^{\circ} \mathrm{C}\right)\end{array}$ & $\mathrm{pH}$ & $\begin{array}{c}\mathrm{C}_{\mathrm{Si}} \\
\mathrm{mg} \mathrm{L}^{-1}\end{array}$ & $\begin{array}{c}\mathrm{C}_{\mathrm{Al}} \\
\mathrm{mg} \mathrm{L}^{-1}\end{array}$ & $\begin{array}{c}\mathrm{C}_{\mathrm{S}} \\
\mathrm{mg} \mathrm{L}^{-1}\end{array}$ & $\begin{array}{c}\mathrm{C}_{\mathrm{Na}} \\
\mathrm{mg} \mathrm{L}^{-1}\end{array}$ & $\begin{array}{c}\mathrm{C}_{\mathrm{Re}} \\
\mu \mathrm{g} \mathrm{L}^{-1}\end{array}$ & $\begin{array}{l}\text { Rate Si } \\
\mathrm{g} \mathrm{m}^{-2} \mathrm{~d}^{-1}\end{array}$ & $\begin{array}{l}\text { Rate Al } \\
\mathrm{g} \mathrm{m}^{-2} \mathrm{~d}^{-1}\end{array}$ & $\begin{array}{c}\text { Rate S } \\
\mathrm{g} \mathrm{m}^{-2} \mathrm{~d}^{-1}\end{array}$ & $\begin{array}{l}\text { Rate Na } \\
\mathrm{g} \mathrm{m}^{-2} \mathrm{~d}^{-1}\end{array}$ & $\begin{array}{l}\text { Rate Re } \\
\mathrm{g} \mathrm{m}^{-2} \mathrm{~d}^{-1}\end{array}$ \\
\hline L24-2-5 & 13 & 40.5 & 7.66 & 0.548 & 0.458 & 0.05 & 1.81 & na & $1.85 \mathrm{E}-04$ & $1.46 \mathrm{E}-04$ & $1.17 \mathrm{E}-03$ & 3.17E-04 & na \\
\hline L24-2-6 & 14 & 40.5 & 7.71 & 0.831 & 0.565 & 0.05 & 2.17 & 0.52 & 2.27E-04 & 1.35E-04 & $9.44 \mathrm{E}-04$ & 5.33E-04 & 5.55E-04 \\
\hline \multicolumn{14}{|c|}{ Cell L31-target $p H 9$} \\
\hline L31-2-1 & 3 & 41.2 & 8.34 & 2.36 & 2.96 & 0.05 & 5.15 & na & 7.06E-04 & 8.58E-04 & 1.03E-03 & $1.71 \mathrm{E}-03$ & na \\
\hline L31-2-2 & 6 & 41 & 8.58 & na & na & na & na & na & na & na & na & na & na \\
\hline L31-2-3 & 8 & 40.9 & 8.52 & 1.65 & 0.077 & 0.05 & 3.57 & 0.29 & 5.18E-04 & $1.66 \mathrm{E}-05$ & $1.08 \mathrm{E}-03$ & $9.07 E-04$ & 3.40E-04 \\
\hline L31-2-4 & 10 & 40.7 & 8.69 & na & na & na & na & na & na & na & na & na & na \\
\hline L31-2-5 & 13 & 40.5 & 8.54 & 1.65 & 0.822 & 0.05 & 2.66 & na & 5.04E-04 & 2.39E-04 & $1.05 \mathrm{E}-03$ & 8.93E-04 & na \\
\hline L31-2-6 & 14 & 40.5 & 8.55 & 2.08 & 2.56 & 0.05 & 2.58 & 0.11 & $5.28 \mathrm{E}-04$ & 6.31E-04 & 8.73E-04 & 5.64E-04 & 8.81E-05 \\
\hline \multicolumn{14}{|c|}{ Cell L27 - target $p H 9$} \\
\hline$\overline{L 27-2-1}$ & 3 & 41.2 & 8.09 & 1.43 & 0.477 & 0.05 & 5.64 & na & 4.72E-04 & $1.47 \mathrm{E}-04$ & $1.14 \mathrm{E}-03$ & 2.07E-03 & na \\
\hline L27-2-2 & 6 & 41 & 8.54 & na & na & na & na & na & na & na & na & na & na \\
\hline L27-2-3 & 8 & 40.9 & 8.47 & 1.31 & 0.176 & 0.05 & 3.91 & 0.30 & 4.58E-04 & 5.23E-05 & $1.20 \mathrm{E}-03$ & $1.14 \mathrm{E}-03$ & 3.93E-04 \\
\hline L27-2-4 & 10 & 40.7 & 8.65 & na & na & na & na & na & na & na & na & na & na \\
\hline L27-2-5 & 13 & 40.5 & 8.46 & 1.29 & 0.092 & 0.05 & 2.61 & na & 4.59E-04 & 2.47E-05 & 1.23E-03 & $1.02 \mathrm{E}-03$ & na \\
\hline L27-2-6 & 14 & 40.5 & 8.49 & 1.25 & 0.151 & 0.05 & 2.13 & 0.57 & $4.50 \mathrm{E}-04$ & 4.83E-05 & $1.24 \mathrm{E}-03$ & $6.21 \mathrm{E}-04$ & 8.03E-04 \\
\hline \multicolumn{14}{|c|}{ Cell L32 - target $p H 10$} \\
\hline L32-2-1 & 3 & 41.2 & 9.1 & 1.8 & 0.116 & 0.127 & 5.4 & na & $6.14 \mathrm{E}-04$ & 3.13E-05 & 2.98E-03 & $1.90 \mathrm{E}-03$ & na \\
\hline L32-2-2 & 6 & 41 & 9.2 & na & na & na & na & na & na & na & na & na & na \\
\hline L32-2-3 & 8 & 40.9 & 9.21 & 1.32 & 0.097 & 0.05 & 2.68 & 0.1 & $4.06 \mathrm{E}-04$ & 2.34E-05 & $1.06 \mathrm{E}-03$ & $9.06 \mathrm{E}-04$ & 9.42E-05 \\
\hline L32-2-4 & 10 & 40.7 & 9.47 & na & na & na & na & na & na & na & na & na & na \\
\hline L32-2-5 & 13 & 40.5 & 9.04 & 1.51 & 2.2 & 0.05 & 2.13 & na & 3.42E-04 & 4.82E-04 & 7.79E-04 & 5.27E-04 & na \\
\hline L32-2-6 & 14 & 40.5 & 9.21 & 1.69 & 2.27 & 0.05 & 1.86 & 0.21 & 4.17E-04 & 5.42E-04 & 8.48E-04 & $5.00 \mathrm{E}-04$ & 1.86E-04 \\
\hline \multicolumn{14}{|c|}{ Cell L23-target $p H 10$} \\
\hline L27-2-1 & 3 & 41.2 & 8.76 & 1.5 & 0.196 & 0.106 & 3.8 & na & $5.24 \mathrm{E}-04$ & 5.94E-05 & $2.55 \mathrm{E}-03$ & $1.32 \mathrm{E}-03$ & na \\
\hline L27-2-2 & 6 & 41 & 9.19 & na & na & na & na & na & na & na & na & na & na \\
\hline L27-2-3 & 8 & 40.9 & 9.2 & 1.4 & 0.214 & 0.05 & 7.58 & 0.47 & $5.00 \mathrm{E}-04$ & 6.81E-05 & 1.23E-03 & 3.01E-03 & 6.50E-04 \\
\hline L27-2-4 & 10 & 40.7 & 9.32 & na & na & na & na & na & na & na & na & na & na \\
\hline L27-2-5 & 13 & 40.5 & 8.97 & 1.5 & 0.281 & 0.05 & 2.53 & na & $5.22 \mathrm{E}-04$ & 8.88E-05 & $1.20 \mathrm{E}-03$ & 9.67E-04 & na \\
\hline L27-2-6 & 14 & 40.5 & 9.12 & 1.56 & 0.354 & 0.05 & 2.65 & 0.97 & 6.53E-04 & $1.37 \mathrm{E}-04$ & $1.44 \mathrm{E}-03$ & $1.22 \mathrm{E}-03$ & $1.62 \mathrm{E}-03$ \\
\hline \multicolumn{14}{|c|}{ " Cell L28-target $p H 11$} \\
\hline$\overline{\mathrm{L} 28-2-1}$ & 3 & 41.2 & 11.02 & 9.19 & 11.4 & 0.369 & 21.4 & na & $3.27 E-03$ & 3.94E-03 & $9.00 \mathrm{E}-03$ & 8.20E-03 & na \\
\hline L28-2-2 & 6 & 41 & 11.17 & na & na & na & na & na & na & na & na & na & na \\
\hline
\end{tabular}


WSRC-TR-2005-00124

Revision 0

\begin{tabular}{|c|c|c|c|c|c|c|c|c|c|c|c|c|c|}
\hline $\begin{array}{c}\text { Sample } \\
\text { ID }\end{array}$ & $\begin{array}{c}\text { Day } \\
\text { sampled }\end{array}$ & $\begin{array}{c}\text { Temp } \\
\left({ }^{\circ} \mathrm{C}\right)\end{array}$ & $\mathrm{pH}$ & $\begin{array}{c}\mathrm{C}_{\mathrm{Si}} \\
\mathrm{mg} \mathrm{L}^{-1}\end{array}$ & $\begin{array}{c}\mathrm{C}_{\mathrm{Al}} \\
\mathrm{mg} \mathrm{L}^{-1}\end{array}$ & $\begin{array}{c}\mathrm{C}_{\mathrm{S}} \\
\mathrm{mg} \mathrm{L}^{-1}\end{array}$ & $\begin{array}{c}\mathrm{C}_{\mathrm{Na}} \\
\mathrm{mg} \mathrm{L}^{-1}\end{array}$ & $\begin{array}{c}\mathrm{C}_{\mathrm{Re}} \\
\mu \mathrm{g} \mathrm{L^{-1 }}\end{array}$ & $\begin{array}{l}\text { Rate Si } \\
\mathrm{g} \mathrm{m}^{-2} \mathrm{~d}^{-1}\end{array}$ & $\begin{array}{l}\text { Rate Al } \\
\mathrm{g} \mathrm{m}^{-2} \mathrm{~d}^{-1}\end{array}$ & $\begin{array}{c}\text { Rate } \mathrm{S} \\
\mathrm{g} \mathrm{m}^{-2} \mathrm{~d}^{-1}\end{array}$ & $\begin{array}{l}\text { Rate Na } \\
\mathrm{g} \mathrm{m}^{-2} \mathrm{~d}^{-1}\end{array}$ & $\begin{array}{l}\text { Rate Re } \\
\mathrm{g} \mathrm{m}^{-2} \mathrm{~d}^{-1}\end{array}$ \\
\hline L28-2-3 & 8 & 40.9 & 11.08 & 8.43 & 9.99 & 0.286 & 12.5 & 16.46 & $2.90 \mathrm{E}-03$ & $3.29 \mathrm{E}-03$ & $6.74 \mathrm{E}-03$ & $4.10 \mathrm{E}-03$ & 2.30E-02 \\
\hline L28-2-4 & 10 & 40.7 & 11.21 & na & na & na & na & na & na & na & na & na & na \\
\hline L28-2-5 & 13 & 40.5 & 10.94 & 8.71 & 9.83 & 0.177 & 9.67 & na & 2.82E-03 & 3.09E-03 & 3.93E-03 & 2.92E-03 & na \\
\hline L28-2-6 & 14 & 40.5 & 11.01 & 5.57 & 6.66 & 0.2 & 9.73 & 8.39 & 1.72E-03 & 1.99E-03 & 4.23E-03 & 3.30E-03 & $1.05 E-02$ \\
\hline \multicolumn{14}{|c|}{ Cell L20-target $p H 11$} \\
\hline L20-2-1 & 3 & 41.2 & 11.08 & 8.4 & 10 & 0.394 & 17 & na & 2.99E-03 & $3.46 \mathrm{E}-03$ & $9.62 \mathrm{E}-03$ & $6.46 \mathrm{E}-03$ & na \\
\hline L20-2-2 & 6 & 41 & 11.17 & na & na & na & na & na & na & na & na & na & na \\
\hline L20-2-3 & 8 & 40.9 & 11.12 & 5.88 & 6.89 & 0.225 & 9.92 & 14.14 & $1.78 \mathrm{E}-03$ & $1.98 \mathrm{E}-03$ & 4.67E-03 & $2.74 \mathrm{E}-03$ & $1.74 \mathrm{E}-02$ \\
\hline L20-2-4 & 10 & 40.7 & 11.3 & na & na & na & na & na & na & na & na & na & na \\
\hline L20-2-5 & 13 & 40.5 & 10.95 & 6.19 & 7.39 & 0.209 & 9.96 & na & 1.91E-03 & 2.21E-03 & 4.41E-03 & 2.88E-03 & na \\
\hline L20-2-6 & 14 & 40.5 & 11.08 & 4.47 & 5.32 & 0.231 & 7.27 & 9.06 & 1.68E-03 & 1.94E-03 & 5.97E-03 & 3.00E-03 & 1.39E-02 \\
\hline
\end{tabular}

$70^{\circ} \mathrm{C}$ and $90^{\circ} \mathrm{C}$ tests

Cell L29-target $p H 7$

\begin{tabular}{|c|c|c|c|c|c|c|c|c|c|c|c|c|c|}
\hline \\
\hline L29-1-1 & 3 & 70.3 & 7.35 & 1.14 & 0.276 & 0.119 & 2.77 & na & 7.68E-04 & $1.79 \mathrm{E}-04$ & 5.53E-03 & $1.79 \mathrm{E}-03$ & na \\
\hline L29-1-2 & 5 & 71.1 & 6.35 & 3.77 & 0.005 & 0.349 & 10.3 & na & $1.12 \mathrm{E}-03$ & na & 7.13E-03 & 2.97E-03 & na \\
\hline L29-1-3 & 7 & 71 & 7.68 & 1.95 & 0.519 & 0.05 & 3.15 & 7.88 & 6.88E-04 & $1.61 \mathrm{E}-04$ & $1.21 \mathrm{E}-03$ & $1.07 \mathrm{E}-03$ & 1.08E-02 \\
\hline L29-1-4 & 10 & 71.4 & 7.3 & 1.91 & 0.49 & 0.132 & 2.81 & na & 6.70E-04 & $1.60 \mathrm{E}-04$ & 3.18E-03 & $9.45 \mathrm{E}-04$ & na \\
\hline L29-1-5 & 12 & 70.8 & 7.57 & 1.92 & 0.45 & 0.166 & 3.1 & na & 6.42E-04 & $1.41 \mathrm{E}-04$ & 3.81E-03 & $9.95 \mathrm{E}-04$ & na \\
\hline L29-1-6 & 14 & 70.5 & 7.73 & 1.75 & 0.394 & 0.154 & 4.32 & 7.44 & $6.44 \mathrm{E}-04$ & 1.33E-04 & 3.90E-03 & $1.54 \mathrm{E}-03$ & 1.07E-02 \\
\hline \multicolumn{14}{|c|}{ Cell L20 - target $p H 7$} \\
\hline L20-1-1 & 3 & 70.3 & 7.38 & 1.08 & 0.217 & 0.115 & 3.13 & na & 6.37E-04 & $1.23 \mathrm{E}-04$ & 4.68E-03 & $2.04 \mathrm{E}-03$ & na \\
\hline L20-1-2 & 5 & 71.1 & 6.02 & 2.9 & 0.005 & 0.319 & 8.78 & na & $1.05 \mathrm{E}-03$ & na & 7.95E-03 & $3.54 \mathrm{E}-03$ & na \\
\hline L20-1-3 & 7 & 71 & 7.59 & 1.66 & 0.435 & 0.199 & 2.48 & 8.18 & $6.28 \mathrm{E}-04$ & $1.41 \mathrm{E}-04$ & $5.18 \mathrm{E}-03$ & $1.03 \mathrm{E}-03$ & 1.21E-02 \\
\hline L20-1-4 & 10 & 71.4 & 7.43 & 1.57 & 0.431 & 0.124 & 2.59 & na & 4.89E-04 & $1.25 \mathrm{E}-04$ & 2.66E-03 & 8.86E-04 & na \\
\hline L20-1-5 & 12 & 70.8 & 7.54 & 1.62 & 0.381 & 0.18 & 3.6 & na & 4.97E-04 & $1.09 \mathrm{E}-04$ & 3.80E-03 & $1.22 \mathrm{E}-03$ & na \\
\hline L20-1-6 & 14 & 70.5 & 7.71 & 1.53 & 0.34 & 0.124 & 2.4 & 7.38 & 5.77E-04 & $1.16 \mathrm{E}-04$ & $3.22 \mathrm{E}-03$ & $9.92 \mathrm{E}-04$ & $1.08 \mathrm{E}-02$ \\
\hline \multicolumn{14}{|c|}{ Cell L24-target $p H 8$} \\
\hline L24-1-1 & 3 & 70.3 & 7.88 & 2.24 & 0.979 & 0.127 & 5.08 & na & $1.46 \mathrm{E}-03$ & 6.18E-04 & 5.68E-03 & 3.13E-03 & na \\
\hline L24-1-2 & 5 & 71.1 & 8.04 & 2.68 & 1.25 & 0.119 & 4.64 & na & 8.63E-04 & 3.91E-04 & 2.63E-03 & $1.54 \mathrm{E}-03$ & na \\
\hline L24-1-3 & 7 & 71 & 7.98 & 2.31 & 1.11 & 0.102 & 3.88 & 4.47 & 6.65E-04 & $3.10 \mathrm{E}-04$ & 2.02E-03 & $1.17 \mathrm{E}-03$ & 4.84E-03 \\
\hline L24-1-4 & 10 & 71.4 & 7.76 & 2.21 & 1.06 & 0.145 & 3.41 & na & 7.92E-04 & 3.69E-04 & 3.57E-03 & 1.35E-03 & na \\
\hline L24-1-5 & 12 & 70.8 & 7.95 & 2.11 & 1.06 & 0.05 & 3.07 & na & 7.03E-04 & 3.39E-04 & $1.15 \mathrm{E}-03$ & $1.13 \mathrm{E}-03$ & na \\
\hline L24-1-6 & 14 & 70.5 & 8.11 & 2.03 & 1 & 0.103 & 2.77 & 4.65 & 1.33E-04 & na & $2.40 \mathrm{E}-03$ & 1.03E-03 & 5.94E-03 \\
\hline
\end{tabular}


WSRC-TR-2005-00124

Revision 0

\begin{tabular}{|c|c|c|c|c|c|c|c|c|c|c|c|c|c|}
\hline $\begin{array}{c}\text { Sample } \\
\text { ID }\end{array}$ & $\begin{array}{c}\text { Day } \\
\text { sampled }\end{array}$ & $\begin{array}{c}\text { Temp } \\
\left({ }^{\circ} \mathrm{C}\right)\end{array}$ & $\mathrm{pH}$ & $\begin{array}{c}\mathrm{C}_{\mathrm{Si}} \\
\mathrm{mg} \mathrm{L}^{-1}\end{array}$ & $\begin{array}{c}\mathrm{C}_{\mathrm{Al}} \\
\mathrm{mg} \mathrm{L}^{-1}\end{array}$ & $\begin{array}{c}\mathrm{C}_{\mathrm{S}} \\
\mathrm{mg} \mathrm{L}^{-1}\end{array}$ & $\begin{array}{c}\mathrm{C}_{\mathrm{Na}} \\
\mathrm{mg} \mathrm{L}^{-1}\end{array}$ & $\begin{array}{c}\mathrm{C}_{\mathrm{Re}} \\
\mu \mathrm{g} \mathrm{L^{-1 }}\end{array}$ & $\begin{array}{l}\text { Rate Si } \\
\mathrm{g} \mathrm{m}^{-2} \mathrm{~d}^{-1}\end{array}$ & $\begin{array}{l}\text { Rate Al } \\
\mathrm{g} \mathrm{m}^{-2} \mathrm{~d}^{-1}\end{array}$ & $\begin{array}{c}\text { Rate S } \\
\mathrm{g} \mathrm{m}^{-2} \mathrm{~d}^{-1}\end{array}$ & $\begin{array}{l}\text { Rate } \mathrm{Na} \\
\mathrm{g} \mathrm{m}^{-2} \mathrm{~d}^{-1}\end{array}$ & $\begin{array}{l}\text { Rate Re } \\
\mathrm{g} \mathrm{m}^{-2} \mathrm{~d}^{-1}\end{array}$ \\
\hline \multicolumn{14}{|c|}{ Cell L18-target $p H 8$} \\
\hline L18-1-1 & 3 & 70.3 & 7.90 & 2.28 & 0.973 & 0.05 & 4.25 & na & $1.45 \mathrm{E}-03$ & 6.02E-04 & 2.19E-03 & 2.48E-03 & na \\
\hline L18-1-2 & 5 & 71.1 & 8.07 & 2.48 & 1.18 & 0.05 & 8.62 & na & 8.23E-04 & 3.80E-04 & 1.14E-03 & 3.07E-03 & na \\
\hline L18-1-3 & 7 & 71 & 8.02 & 2.19 & 1.09 & 0.13 & 3.5 & 5.37 & 6.49E-04 & 3.14E-04 & 2.65E-03 & 1.08E-03 & 6.07E-03 \\
\hline L18-1-4 & 10 & 71.4 & 7.72 & 2.12 & 1.07 & 0.126 & 3.14 & na & 6.82E-04 & 3.34E-04 & 2.78E-03 & 1.11E-03 & na \\
\hline L18-1-5 & 12 & 70.8 & 8.00 & 2.07 & 1.07 & 0.12 & 2.93 & na & 5.94E-04 & 2.95E-04 & 2.37E-03 & $9.24 \mathrm{E}-04$ & na \\
\hline L18-1-6 & 14 & 70.5 & 8.14 & 1.99 & 0.988 & 0.103 & 2.61 & 5.71 & $1.21 \mathrm{E}-04$ & na & 2.44E-03 & 9.88E-04 & 7.55E-03 \\
\hline \multicolumn{14}{|c|}{ Cell L33 - target $p H 9$} \\
\hline L33-1-1 & 3 & 70.3 & 8.68 & 3.06 & 0.169 & 0.05 & 5.95 & na & 1.92E-03 & 9.33E-05 & 2.15E-03 & 4.12E-03 & na \\
\hline L33-1-2 & 5 & 71.1 & 8.76 & 3.58 & 0.103 & 0.05 & 7.32 & na & $1.27 \mathrm{E}-03$ & 3.10E-05 & $1.21 \mathrm{E}-03$ & 2.87E-03 & na \\
\hline L33-1-3 & 7 & 71 & 8.74 & 3.3 & 0.112 & 0.05 & 6.08 & 0.35 & $1.25 \mathrm{E}-03$ & 3.70E-05 & 1.30E-03 & 2.32E-03 & na \\
\hline L33-1-4 & 10 & 71.4 & 8.51 & 3.45 & 0.126 & 0.05 & 6.61 & na & $1.28 \mathrm{E}-03$ & 4.11E-05 & 1.27E-03 & 2.71E-03 & na \\
\hline L33-1-5 & 12 & 70.8 & 8.73 & 3.83 & 0.905 & 0.05 & 5.81 & 1.61 & 1.23E-03 & 2.78E-04 & 1.10E-03 & 2.06E-03 & 2.10E-03 \\
\hline L33-1-6 & 14 & 70.5 & na & na & na & na & na & na & na & na & na & na & na \\
\hline \multicolumn{14}{|c|}{ Cell L25 - target $p H 9$} \\
\hline L25-1-1 & 3 & 70.3 & 8.67 & 2.7 & 0.377 & 0.05 & 5.08 & na & 1.83E-03 & 2.38E-04 & 2.33E-03 & 3.81E-03 & na \\
\hline L25-1-2 & 5 & 71.1 & 8.79 & 3.77 & 0.294 & 0.05 & 6.68 & na & $1.16 \mathrm{E}-03$ & 8.38E-05 & 1.05E-03 & 2.27E-03 & na \\
\hline L25-1-3 & 7 & 71 & 8.77 & 3.3 & 0.181 & 0.05 & 5.96 & 0.35 & $1.26 \mathrm{E}-03$ & $6.26 \mathrm{E}-05$ & 1.30E-03 & 2.27E-03 & na \\
\hline L25-1-4 & 10 & 71.4 & 8.55 & 3.73 & 0.908 & 0.05 & 6.39 & na & $1.15 \mathrm{E}-03$ & 2.70E-04 & 1.06E-03 & 2.19E-03 & na \\
\hline L25-1-5 & 12 & 70.8 & 8.76 & 3.72 & 0.959 & 0.05 & 5.37 & na & $1.10 \mathrm{E}-03$ & 2.73E-04 & $1.02 \mathrm{E}-03$ & $1.76 \mathrm{E}-03$ & na \\
\hline L25-1-6 & 14 & 70.5 & 8.80 & 3.77 & 1.37 & 0.05 & 5.33 & 2.01 & $1.44 \mathrm{E}-03$ & 5.02E-04 & 1.31E-03 & 2.19E-03 & 2.57E-03 \\
\hline \multicolumn{14}{|c|}{ Cell L14-target $p H 10$} \\
\hline L14-1-1 & 3 & 70.3 & 9.65 & 2.33 & 0.501 & 0.05 & 3.65 & na & $1.66 \mathrm{E}-03$ & 3.31E-04 & 2.45E-03 & 2.87E-03 & na \\
\hline L14-1-2 & 5 & 71.1 & 9.8 & 4 & 0.322 & 0.05 & 6.73 & na & $1.28 \mathrm{E}-03$ & 9.48E-05 & 1.09E-03 & 2.00E-03 & na \\
\hline L14-1-3 & 7 & 71 & 9.68 & 3.39 & 0.162 & 0.05 & 5.5 & 0.35 & $1.20 \mathrm{E}-03$ & 5.01E-05 & $1.22 \mathrm{E}-03$ & 2.16E-03 & na \\
\hline L14-1-4 & 10 & 71.4 & 9.39 & 3.48 & 0.156 & 0.05 & 5.8 & na & $1.22 \mathrm{E}-03$ & 4.67E-05 & 1.20E-03 & 2.25E-03 & na \\
\hline L14-1-5 & 12 & 70.8 & 9.61 & 4.31 & 0.472 & 0.05 & 7.15 & na & $1.35 \mathrm{E}-03$ & 1.35E-04 & 1.08E-03 & 2.49E-03 & na \\
\hline L14-1-6 & 14 & 70.5 & 9.43 & 3.96 & 0.296 & 0.05 & 6.57 & 1.05 & $1.44 \mathrm{E}-03$ & 9.69E-05 & $1.25 \mathrm{E}-03$ & 2.65E-03 & $1.04 \mathrm{E}-03$ \\
\hline \multicolumn{14}{|c|}{ Cell L32 - target $p H 10$} \\
\hline L32-1-1 & 3 & 70.3 & 9.69 & 2.67 & 0.502 & 0.05 & 4.01 & na & 1.73E-03 & 3.00E-04 & 2.22E-03 & 2.86E-03 & na \\
\hline L32-1-2 & 5 & 71.1 & 9.87 & 4.03 & 0.256 & 0.05 & 7.12 & na & $1.41 \mathrm{E}-03$ & 8.13E-05 & $1.20 \mathrm{E}-03$ & 2.34E-03 & na \\
\hline L32-1-3 & 7 & 71 & 9.74 & 4.1 & 0.389 & 0.05 & 6.88 & 0.35 & $1.41 \mathrm{E}-03$ & $1.25 \mathrm{E}-04$ & 1.18E-03 & 2.62E-03 & na \\
\hline L32-1-4 & 10 & 71.4 & 9.40 & 3.96 & 0.192 & 0.05 & 6.94 & na & 1.37E-03 & 5.84E-05 & 1.19E-03 & 2.67E-03 & na \\
\hline L32-1-5 & 12 & 70.8 & 9.63 & 4.41 & 0.198 & 0.05 & 9.13 & na & 1.47E-03 & 5.47E-05 & 1.15E-03 & 3.39E-03 & na \\
\hline
\end{tabular}


WSRC-TR-2005-00124

Revision 0

\begin{tabular}{|c|c|c|c|c|c|c|c|c|c|c|c|c|c|}
\hline $\begin{array}{c}\text { Sample } \\
\text { ID }\end{array}$ & $\begin{array}{c}\text { Day } \\
\text { sampled }\end{array}$ & $\begin{array}{l}\text { Temp } \\
\left({ }^{\circ} \mathrm{C}\right)\end{array}$ & $\mathrm{pH}$ & $\begin{array}{c}\mathrm{C}_{\mathrm{Si}} \\
\mathrm{mg} \mathrm{L}^{-1}\end{array}$ & $\begin{array}{r}\mathrm{C}_{\mathrm{Al}} \\
\mathrm{mg} \mathrm{L}^{-1} \\
\end{array}$ & $\begin{array}{c}\mathrm{C}_{\mathrm{S}} \\
\mathrm{mg} \mathrm{L}^{-1} \\
\end{array}$ & $\begin{array}{c}\mathrm{C}_{\mathrm{Na}} \\
\mathrm{mg} \mathrm{L}^{-1}\end{array}$ & $\begin{array}{c}\mathrm{C}_{\mathrm{Re}} \\
\mu \mathrm{g} \mathrm{L}^{-1} \\
\end{array}$ & $\begin{array}{l}\text { Rate Si } \\
\mathrm{g} \mathrm{m}^{-2} \mathrm{~d}^{-1}\end{array}$ & $\begin{array}{l}\text { Rate Al } \\
\mathrm{g} \mathrm{m}^{-2} \mathrm{~d}^{-1}\end{array}$ & $\begin{array}{c}\text { Rate S } \\
\mathrm{g} \mathrm{m}^{-2} \mathrm{~d}^{-1}\end{array}$ & $\begin{array}{l}\text { Rate Na } \\
\mathrm{g} \mathrm{m}^{-2} \mathrm{~d}^{-1}\end{array}$ & $\begin{array}{l}\text { Rate Re } \\
\mathrm{g} \mathrm{m}^{-2} \mathrm{~d}^{-1}\end{array}$ \\
\hline L32-1-6 & 14 & 70.5 & 9.50 & 4.29 & 0.296 & 0.05 & 7.92 & 1.02 & $1.35 \mathrm{E}-03$ & $8.39 \mathrm{E}-05$ & $1.08 \mathrm{E}-03$ & $2.77 \mathrm{E}-03$ & $8.61 \mathrm{E}-04$ \\
\hline \multicolumn{14}{|c|}{ Cell L13-target $p H 11$} \\
\hline L13-1-1 & 3 & 70.3 & 11.35 & 14.7 & 16.5 & 0.519 & 23.6 & na & $9.72 \mathrm{E}-03$ & $1.06 \mathrm{E}-02$ & 2.35E-02 & $1.74 \mathrm{E}-02$ & na \\
\hline L13-1-2 & 5 & 71.1 & 11.45 & 19.4 & 22.2 & 0.557 & 22.7 & na & 6.38E-03 & 7.09E-03 & $1.25 \mathrm{E}-02$ & 8.30E-03 & na \\
\hline L13-1-3 & 7 & 71 & 11.46 & 15.8 & 18 & 0.558 & 16.1 & 32.4 & 4.25E-03 & 4.70E-03 & 1.03E-02 & 4.81E-03 & 3.51E-02 \\
\hline L13-1-4 & 10 & 71.4 & 11.1 & 19.7 & 22.4 & 0.619 & 15 & na & 5.30E-03 & 5.84E-03 & $1.14 \mathrm{E}-02$ & 4.36E-03 & na \\
\hline L13-1-5 & 12 & 70.8 & 11.32 & 16.9 & 19 & 0.458 & 9.65 & na & 5.19E-03 & 5.65E-03 & $9.62 \mathrm{E}-03$ & 3.28E-03 & na \\
\hline L13-1-6 & 14 & 70.5 & 11.2 & 13.2 & 14.9 & 0.306 & 7.47 & 17.3 & 4.30E-03 & 4.71E-03 & 6.81E-03 & 2.70E-03 & 2.29E-02 \\
\hline \multicolumn{14}{|c|}{ Cell L30 - target $p H 11$} \\
\hline L30-1-1 & 3 & 70.3 & .41 & 14.7 & 16.6 & 577 & 21.5 & na & $9.48 \mathrm{E}-03$ & 1.0 & 2.55E-02 & 1.5 & na \\
\hline L30-1-2 & 5 & 71.1 & 11.45 & 19.6 & 22.3 & 0.52 & 22.5 & na & 6.62E-03 & 7.32 & $1.20 \mathrm{E}-02$ & 8.4 & na \\
\hline $0-1-3$ & 7 & 71 & 11.46 & 17.9 & 20.3 & 0.454 & 17.4 & .0291 & 5.12E-03 & 5.63E-03 & 8.89E-03 & 5.52 & 3.34E-02 \\
\hline L30-1-4 & 10 & 71.4 & 11.09 & 16.5 & 18.6 & 0.463 & 13 & na & 5.52E-03 & 6.04E-03 & $1.06 \mathrm{E}-02$ & 4.69E-03 & na \\
\hline L30-1-5 & 12 & 70.8 & 11.34 & 16.8 & 19 & 0.287 & 11.1 & na & 4.91E-03 & 5.38E-03 & 5.73E-03 & 3.59 & na \\
\hline L30-1-6 & 14 & 70.5 & 11.21 & 14.5 & 16.4 & 0.271 & 9.86 & 0.01 & 4.09E-03 & 4.49 & 5.23E-03 & 3.10 & $1.83 \mathrm{E}-02$ \\
\hline \multicolumn{14}{|c|}{ Cell L19-target $p H 7$} \\
\hline L19-1-1 & 3 & 90 & 7.03 & 3.42 & 0.414 & 0.264 & 6.37 & 15.6 & 2.32E-03 & 2.70 & 1.23E-02 & 4.77 & 4.30E-02 \\
\hline $1-2$ & 5 & 90.4 & 6.07 & 7.31 & 0.027 & 0.445 & 15.5 & 35.9 & 2.37E-03 & 6.93E-06 & 9.87E-03 & 5.57 & 4.73E-02 \\
\hline L19-1-3 & 7 & 90.1 & 7.54 & 5.83 & 1.06 & 0.178 & 7 & 12.1 & $1.86 \mathrm{E}-03$ & 3.13E-04 & 3.89E-03 & 2.47 & $1.53 \mathrm{E}-02$ \\
\hline L19-1-4 & 10 & 90.5 & 7.22 & 5.26 & 0.701 & 0.118 & 6.6 & 8.93 & $1.60 \mathrm{E}-03$ & $2.02 \mathrm{E}-04$ & $2.47 \mathrm{E}-03$ & 2.23E-03 & $1.11 \mathrm{E}-02$ \\
\hline L19-1-5 & 12 & 90.1 & 7.21 & 5.29 & 0.633 & 0.13 & 7.58 & 8.53 & $1.62 \mathrm{E}-03$ & 1.83E-04 & 2.72E-03 & $2.56 \mathrm{E}-03$ & $1.06 \mathrm{E}-02$ \\
\hline L19-1-6 & 14 & 90.1 & 7.73 & 5.29 & 0.581 & 0.05 & 6.83 & 7.03 & $1.85 \mathrm{E}-03$ & 1.90E-04 & $1.20 \mathrm{E}-03$ & 2.65E-03 & $9.52 \mathrm{E}-03$ \\
\hline \multicolumn{14}{|c|}{ Cell L09-target $p H 7$} \\
\hline L09-1-1 & 3 & 90 & 7.13 & 2.67 & 0.364 & 0.191 & 5.8 & na & $1.90 \mathrm{E}-03$ & 2.48E-04 & 9.31E-03 & 4.56E-03 & na \\
\hline L09-1-2 & 5 & 90.4 & 7.03 & 5.92 & 0.273 & 0.552 & 6.51 & na & $1.94 \mathrm{E}-03$ & 8.54E-05 & $1.24 \mathrm{E}-02$ & 2.36E-03 & na \\
\hline L09-1-3 & 7 & 90.1 & 7.53 & 4.79 & 0.813 & 0.173 & 7.03 & na & $1.60 \mathrm{E}-03$ & 2.47E-04 & 3.96E-03 & 2.60E-03 & na \\
\hline L09-1-4 & 10 & 90.5 & 7.35 & 4.79 & 0.682 & 0.136 & 6.94 & 10.1 & $1.41 \mathrm{E}-03$ & 1.89E-04 & 2.73E-03 & 2.25E-03 & na \\
\hline L09-1-5 & 12 & 90.1 & 7.18 & 5.09 & 0.615 & 0.146 & 6.75 & na & $1.61 \mathrm{E}-03$ & $1.84 \mathrm{E}-04$ & 3.16E-03 & 2.36E-03 & na \\
\hline L09-1-6 & 14 & 90.1 & 7.81 & 4.75 & 0.583 & 0.103 & 6.33 & 5.58 & $1.34 \mathrm{E}-03$ & 1.53E-04 & $1.99 \mathrm{E}-03$ & $1.97 \mathrm{E}-03$ & $5.99 \mathrm{E}-03$ \\
\hline \multicolumn{14}{|c|}{ 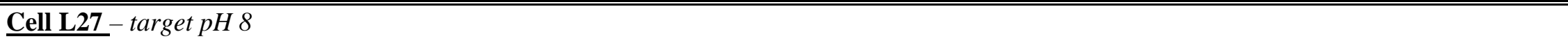 } \\
\hline L27-1-1 & 3 & 90 & 7.63 & 3.84 & 1.32 & 0.169 & 7.09 & na & 2.18E-03 & 7.26E-04 & 6.57E-03 & 4.00E-03 & na \\
\hline L27-1-2 & 5 & 90.4 & 7.61 & 5.34 & 1.62 & 0.258 & 10.1 & na & 1.83E-03 & 5.37E-04 & $6.04 \mathrm{E}-03$ & 3.72E-03 & na \\
\hline L27-1-3 & 7 & 90.1 & 7.8 & 5.44 & 1.52 & 0.267 & 8.33 & 13.8 & $1.74 \mathrm{E}-03$ & 4.71E-04 & 5.85E-03 & 2.89E-03 & $1.75 \mathrm{E}-02$ \\
\hline
\end{tabular}


WSRC-TR-2005-00124

Revision 0

\begin{tabular}{|c|c|c|c|c|c|c|c|c|c|c|c|c|c|}
\hline $\begin{array}{c}\text { Sample } \\
\text { ID }\end{array}$ & $\begin{array}{c}\text { Day } \\
\text { sampled }\end{array}$ & $\begin{array}{l}\text { Temp } \\
\left({ }^{\circ} \mathrm{C}\right)\end{array}$ & $\mathrm{pH}$ & $\begin{array}{c}\mathrm{C}_{\mathrm{Si}} \\
\mathrm{mg} \mathrm{L}^{-1}\end{array}$ & $\begin{array}{c}\mathrm{C}_{\mathrm{Al}} \\
\mathrm{mg} \mathrm{L}^{-1}\end{array}$ & $\begin{array}{c}\mathrm{C}_{\mathrm{S}} \\
\mathrm{mg} \mathrm{L}^{-1}\end{array}$ & $\begin{array}{c}\mathrm{C}_{\mathrm{Na}} \\
\mathrm{mg} \mathrm{L}^{-1}\end{array}$ & $\begin{array}{c}\mathrm{C}_{\mathrm{Re}} \\
\mu \mathrm{g} \mathrm{L}{ }^{-1}\end{array}$ & $\begin{array}{l}\text { Rate Si } \\
\mathrm{g} \mathrm{m}^{-2} \mathrm{~d}^{-1}\end{array}$ & $\begin{array}{l}\text { Rate Al } \\
\mathrm{g} \mathrm{m}^{-2} \mathrm{~d}^{-1}\end{array}$ & $\begin{array}{c}\text { Rate S } \\
\mathrm{g} \mathrm{m}^{-2} \mathrm{~d}^{-1}\end{array}$ & $\begin{array}{l}\text { Rate Na } \\
\mathrm{g} \mathrm{m}^{-2} \mathrm{~d}^{-1}\end{array}$ & $\begin{array}{l}\text { Rate Re } \\
\mathrm{g} \mathrm{m}^{-2} \mathrm{~d}^{-1}\end{array}$ \\
\hline L27-1-4 & 10 & 90.5 & 7.53 & 6.13 & 1.6 & 0.206 & 7.96 & na & $1.94 \mathrm{E}-03$ & 4.92E-04 & $4.48 \mathrm{E}-03$ & $2.80 \mathrm{E}-03$ & na \\
\hline L27-1-5 & 12 & 90.1 & 7.64 & 5.2 & 1.33 & 0.05 & 6.42 & na & 1.62E-03 & $3.98 \mathrm{E}-04$ & 1.07E-03 & 2.21E-03 & na \\
\hline L27-1-6 & 14 & 90.1 & 8.14 & 5.54 & 1.36 & 0.172 & 6.92 & 10.3 & 1.31E-03 & na & 3.95E-03 & 2.56E-03 & 1.36E-02 \\
\hline \multicolumn{14}{|c|}{ Cell L10-target $p H 8$} \\
\hline L10-1-1 & 3 & 90 & 7.59 & 3.25 & 1.09 & 0.185 & 6.83 & na & 2.20E-03 & 7.15E-04 & 8.59E-03 & 4.58E-03 & na \\
\hline L10-1-2 & 5 & 90.4 & 7.67 & 5.14 & 1.59 & 0.281 & 8.97 & na & 1.62E-03 & 4.87E-04 & $6.08 \mathrm{E}-03$ & 3.04E-03 & na \\
\hline L10-1-3 & 7 & 90.1 & 7.77 & 4.84 & 1.39 & 0.259 & 8.27 & 13.8 & 1.61E-03 & 4.50E-04 & 5.92E-03 & 2.99E-03 & 1.83E-02 \\
\hline L10-1-4 & 10 & 90.5 & 7.61 & 5.21 & 1.4 & 0.192 & 7.06 & na & 1.70E-03 & 4.43E-04 & 4.29E-03 & 2.55E-03 & na \\
\hline L10-1-5 & 12 & 90.1 & 7.60 & 5.28 & 1.41 & 0.148 & 6.9 & na & 1.61E-03 & 4.13E-04 & 3.09E-03 & 2.33E-03 & na \\
\hline L10-1-6 & 14 & 90.1 & 8.15 & 5.11 & 1.3 & 0.144 & 6.38 & 9.46 & 1.12E-03 & na & $3.18 \mathrm{E}-03$ & 2.27E-03 & 1.19E-02 \\
\hline \multicolumn{14}{|c|}{ Cell L31 - target $p H 9$} \\
\hline L31-1-1 & 3 & 90 & 8.47 & 5.54 & 2.24 & 0.153 & 10.5 & na & 3.86E-03 & $1.51 \mathrm{E}-03$ & 7.31E-03 & 8.12E-03 & na \\
\hline L31-1-2 & 5 & 90.4 & 8.35 & 5.02 & 0.079 & 0.05 & 12.2 & na & 1.70E-03 & 2.17E-05 & $1.16 \mathrm{E}-03$ & 4.59E-03 & na \\
\hline L31-1-3 & 7 & 90.1 & 8.6 & 5.23 & 0.019 & 0.05 & 11.1 & 2.43 & 1.50E-03 & 1.95E-06 & $9.82 \mathrm{E}-04$ & 3.35E-03 & 2.43E-03 \\
\hline L31-1-4 & 10 & 90.5 & 8.41 & 4.7 & 0.105 & 0.154 & 11.2 & na & 1.67E-03 & $3.22 \mathrm{E}-05$ & 3.76E-03 & 4.42E-03 & na \\
\hline L31-1-5 & 12 & 90.1 & 8.3 & 7.07 & 6 & 0.05 & 8.69 & na & 1.88E-03 & na & $9.10 \mathrm{E}-04$ & 2.56E-03 & na \\
\hline L31-1-6 & 14 & 90.1 & 8.83 & 4.23 & 0.121 & 0.05 & 9.01 & 9.51 & 1.43E-03 & 3.49E-05 & 1.16E-03 & 3.33E-03 & $1.26 \mathrm{E}-02$ \\
\hline \multicolumn{14}{|c|}{ Cell L15-target $p H 9$} \\
\hline L15-1-1 & 3 & 90 & 8.75 & na & na & na & na & na & na & na & na & na & na \\
\hline L15-1-2 & 5 & 90.4 & 8.31 & 4.31 & 0.109 & 0.146 & 9.85 & na & 1.61E-03 & 3.49E-05 & $3.74 \mathrm{E}-03$ & 4.08E-03 & na \\
\hline L15-1-3 & 7 & 90.1 & 8.63 & 4.83 & 0.121 & 0.05 & 10.9 & 1.21 & 1.74E-03 & 3.83E-05 & $1.24 \mathrm{E}-03$ & 4.15E-03 & $1.26 \mathrm{E}-03$ \\
\hline L15-1-4 & 10 & 90.5 & 8.53 & 7.22 & 6.08 & 0.05 & 9.31 & na & 1.16E-03 & na & 5.49E-04 & 1.66E-03 & na \\
\hline L15-1-5 & 12 & 90.1 & 8.22 & 4.29 & 0.016 & 0.13 & 9.23 & na & 1.40E-03 & 9.53E-07 & 2.91E-03 & 3.34E-03 & na \\
\hline L15-1-6 & 14 & 90.1 & 8.85 & 3.82 & 0.049 & 0.164 & 8.03 & 7.59 & 1.35E-03 & 1.17E-05 & 3.98E-03 & $3.10 \mathrm{E}-03$ & $1.04 \mathrm{E}-02$ \\
\hline \multicolumn{14}{|c|}{ Cell L26-target $p H 10$} \\
\hline L26-1-1 & 3 & 90 & 9.44 & 5.78 & 1.57 & 0.05 & 9.73 & na & 3.83E-03 & 9.97E-04 & 2.27E-03 & 7.16E-03 & na \\
\hline L26-1-2 & 5 & 90.4 & 9.39 & 5.96 & 0.141 & 0.05 & 13.6 & na & 2.00E-03 & 4.05E-05 & 1.15E-03 & 4.67E-03 & na \\
\hline L26-1-3 & 7 & 90.1 & 9.5 & 6.37 & 0.442 & 0.05 & 13.7 & 2.83 & 1.92E-03 & $1.24 \mathrm{E}-04$ & 1.03E-03 & 4.57E-03 & 3.03E-03 \\
\hline L26-1-4 & 10 & 90.5 & 9.1 & 5.82 & 0.191 & 0.05 & 12.6 & na & 1.93E-03 & 5.53E-05 & 1.13E-03 & 4.63E-03 & na \\
\hline L26-1-5 & 12 & 90.1 & 8.89 & 5.27 & 0.071 & 0.131 & 10.9 & na & 1.62E-03 & 1.23E-05 & 2.78E-03 & 3.74E-03 & na \\
\hline L26-1-6 & 14 & 90.1 & 9.5 & 5.07 & 0.122 & 0.242 & 10.9 & 13.5 & 1.72E-03 & $3.26 \mathrm{E}-05$ & 5.62E-03 & 4.10E-03 & $1.81 \mathrm{E}-02$ \\
\hline \multicolumn{14}{|c|}{ Cell L23-target $p H 10$} \\
\hline L23-1-1 & 3 & 90 & 9.82 & 9.24 & 8.54 & 2.08 & 41.6 & na & 6.59E-03 & 5.91E-03 & 1.02E-01 & 3.30E-02 & na \\
\hline L23-1-2 & 5 & 90.4 & 9.21 & 9.37 & 4.98 & 0.05 & 17.5 & na & 3.47E-03 & 1.79E-03 & 1.27E-03 & 6.76E-03 & na \\
\hline
\end{tabular}


WSRC-TR-2005-00124

Revision 0

\begin{tabular}{|c|c|c|c|c|c|c|c|c|c|c|c|c|c|}
\hline $\begin{array}{c}\text { Sample } \\
\text { ID }\end{array}$ & $\begin{array}{c}\text { Day } \\
\text { sampled }\end{array}$ & $\begin{array}{c}\text { Temp } \\
\left({ }^{\circ} \mathrm{C}\right)\end{array}$ & $\mathrm{pH}$ & $\begin{array}{c}\mathrm{C}_{\mathrm{Si}} \\
\mathrm{mg} \mathrm{L}^{-1}\end{array}$ & $\begin{array}{r}\mathrm{C}_{\mathrm{Al}} \\
\mathrm{mg} \mathrm{L}^{-1}\end{array}$ & $\begin{array}{c}\mathrm{C}_{\mathrm{S}} \\
\mathrm{mg} \mathrm{L}^{-1} \\
\end{array}$ & $\begin{array}{c}\mathrm{C}_{\mathrm{Na}} \\
\mathrm{mg} \mathrm{L}^{-1}\end{array}$ & $\begin{array}{c}\mathrm{C}_{\mathrm{Re}} \\
\mu \mathrm{g} \mathrm{L}^{-1} \\
\end{array}$ & $\begin{array}{l}\text { Rate Si } \\
\mathrm{g} \mathrm{m}^{-2} \mathrm{~d}^{-1}\end{array}$ & $\begin{array}{l}\text { Rate Al } \\
\mathrm{g} \mathrm{m}^{-2} \mathrm{~d}^{-1}\end{array}$ & $\begin{array}{c}\text { Rate S } \\
\mathrm{g} \mathrm{m}^{-2} \mathrm{~d}^{-1}\end{array}$ & $\begin{array}{l}\text { Rate Na } \\
\mathrm{g} \mathrm{m}^{-2} \mathrm{~d}^{-1}\end{array}$ & $\begin{array}{l}\text { Rate Re } \\
\mathrm{g} \mathrm{m}^{-2} \mathrm{~d}^{-1}\end{array}$ \\
\hline L23-1-3 & 7 & 90.1 & 9.47 & 5.38 & 0.265 & 0.05 & 12.4 & 1.44 & 1.89E-03 & $8.46 \mathrm{E}-05$ & $1.20 \mathrm{E}-03$ & 4.83E-03 & $1.55 \mathrm{E}-03$ \\
\hline L23-1-4 & 10 & 90.5 & 9.22 & 7.15 & 0.63 & 0.05 & 17.9 & na & 2.35E-03 & $1.95 \mathrm{E}-04$ & $1.12 \mathrm{E}-03$ & $6.53 \mathrm{E}-03$ & na \\
\hline L23-1-5 & 12 & 90.1 & 8.96 & 5.58 & 0.214 & 0.05 & 12.9 & na & $1.91 \mathrm{E}-03$ & 6.16 & $1.18 \mathrm{E}-03$ & 4.9 & na \\
\hline L23-1-6 & 14 & 90.1 & 9.53 & 6.11 & 0.206 & 0.05 & 14.4 & 2.34 & 2.00 & 5.82E-05 & $1.12 \mathrm{E}-03$ & 5.23E-03 & 2.65E-03 \\
\hline \multicolumn{14}{|c|}{ Cell L34 - target $p H 11$} \\
\hline L34-1-1 & 3 & 90 & 11.11 & 16.8 & 18.9 & 0.416 & 37.4 & na & $1.21 \mathrm{E}-02$ & 1.32E-02 & 2.05E-02 & 2.99E-02 & na \\
\hline L34-1-2 & 5 & 90.4 & 10.99 & 24.6 & 28.2 & 0.665 & 44.4 & na & 8.2 & $9.21 \mathrm{E}-03$ & $1.53 \mathrm{E}-02$ & $1.66 \mathrm{E}-02$ & na \\
\hline L34-1-3 & 7 & 90.1 & 11.14 & 22.8 & 25.9 & 0.72 & 29.8 & 51.1 & 7.45E-03 & 8.21E-03 & $1.61 \mathrm{E}-02$ & $1.08 \mathrm{E}-02$ & 6.73E-02 \\
\hline L34-1-4 & 10 & 90.5 & 11 & 23.6 & 26.8 & 0.542 & 16.1 & na & 7.72 & 8.51E-03 & $1.21 \mathrm{E}-02$ & 5.71E-03 & na \\
\hline L34-1-5 & 12 & 90.1 & 11.09 & 19.4 & 21.6 & 0.337 & 11.1 & na & 5.57 & 6.01E-03 & 6.62E-03 & 3.53E-03 & na \\
\hline L34-1-6 & 14 & 90.1 & 11.15 & 17.9 & 20 & 0.266 & 10.9 & 14.2 & $6.08 \mathrm{E}-03$ & $6.60 \mathrm{E}-03$ & 6.18E-03 & 4.12E-03 & $1.96 \mathrm{E}-02$ \\
\hline \multicolumn{14}{|c|}{ Cell L21 - target $p H 11$} \\
\hline L21-1-1 & 3 & 90 & 11.22 & 17.5 & 19.8 & 0.716 & 31.1 & na & $1.24 \mathrm{E}-02$ & $1.36 \mathrm{E}-02$ & $3.46 \mathrm{E}-02$ & 2.44E-02 & na \\
\hline L21-1-2 & 5 & 90.4 & 11.10 & 27.3 & 30.7 & 0.827 & 33.2 & na & $1.00 \mathrm{E}-02$ & $1.10 \mathrm{E}-02$ & 2.08E-02 & 1.36E-02 & na \\
\hline L21-1-3 & 7 & 90.1 & 11.28 & 25.5 & 28.2 & 0.782 & 20.9 & 50.9 & 9.37E-03 & $1.01 \mathrm{E}-02$ & 1.97E-02 & 8.53E-03 & 7.54E-02 \\
\hline L21-1-4 & 10 & 90.5 & 11.09 & 24.3 & 27.3 & 0.376 & 13 & na & 7.47E-03 & $8.14 \mathrm{E}-03$ & 7.91E-03 & 4.31E-03 & na \\
\hline L21-1-5 & 12 & 90.1 & 11.22 & 22.1 & 24.6 & 0.147 & 12.3 & na & 5.87E-03 & 6.34E-03 & 2.67E-03 & $3.62 \mathrm{E}-03$ & na \\
\hline L21-1-6 & 14 & 90.1 & 11.17 & 18 & 20 & 0.164 & 9.86 & 7.63 & 6.52E-03 & $7.04 \mathrm{E}-03$ & $4.06 \mathrm{E}-03$ & $3.98 \mathrm{E}-03$ & $1.12 \mathrm{E}-02$ \\
\hline
\end{tabular}

na $=$ not analyzed 
WSRC-TR-2005-00124

Revision 0

Table A2. Average of the Log of the Release Rates and Standard Deviations for tests with LAW 1123 bed product

\begin{tabular}{|c|c|c|c|c|c|c|c|c|c|c|c|c|}
\hline $\begin{array}{c}\text { Sample } \\
\text { ID }\end{array}$ & $\begin{array}{c}\text { Day } \\
\text { sampled }\end{array}$ & $\begin{array}{l}\text { Target } \\
\text { Temp } \\
\left({ }^{\circ} \mathrm{C}\right)\end{array}$ & $\begin{array}{c}\text { Average } \\
\text { Log Rate } \\
\text { Si } \\
\mathrm{g} \mathrm{m}^{-2} \mathrm{~d}^{-1}\end{array}$ & $\begin{array}{l}\text { Standard } \\
\text { Dev.. Si }\end{array}$ & $\begin{array}{c}\text { Average } \\
\text { Log Rate } \\
\mathrm{Al} \\
\mathrm{g} \mathrm{m}^{-2} \mathrm{~d}^{-1}\end{array}$ & $\begin{array}{c}\text { Standard } \\
\text { Dev. Al }\end{array}$ & $\begin{array}{c}\text { Average } \\
\text { Log Rate } \\
\mathrm{S} \\
\mathrm{g} \mathrm{m}^{-2} \mathrm{~d}^{-1}\end{array}$ & $\begin{array}{c}\text { Standard } \\
\text { Dev. S }\end{array}$ & $\begin{array}{c}\text { Average } \\
\text { Log Rate } \\
\text { Na } \\
\mathrm{g} \mathrm{m}^{-2} \mathrm{~d}^{-1}\end{array}$ & $\begin{array}{l}\text { Standard } \\
\text { Dev. Na }\end{array}$ & $\begin{array}{c}\text { Average } \\
\text { Log Rate } \\
\text { Re } \\
\mathrm{g} \mathrm{m}^{-2} \mathrm{~d}^{-1} \\
\end{array}$ & $\begin{array}{l}\text { Standard } \\
\text { Dev. Re }\end{array}$ \\
\hline \multicolumn{13}{|c|}{$25^{\circ} \mathrm{C}$ and $40^{\circ} \mathrm{C}$ tests } \\
\hline \multicolumn{13}{|c|}{ Cell L19/L14-target $p H 7$} \\
\hline Avg. & 3 & 25 & -4.04 & 0.03 & -4.13 & 0.08 & -1.53 & 0.10 & -2.43 & 0.08 & na & na \\
\hline Avg. & 8 & 25 & -3.90 & 0.08 & -4.54 & 0.00 & -2.94 & 0.01 & -3.11 & 0.04 & -2.84 & 0.00 \\
\hline Avg. & 13 & 25 & -4.07 & 0.13 & -4.62 & 0.04 & -2.93 & 0.02 & -3.31 & 0.05 & na & na \\
\hline Avg. & 14 & 25 & -3.91 & 0.22 & -4.80 & 0.22 & -3.00 & 0.05 & -3.27 & 0.15 & -3.09 & 0.27 \\
\hline \multicolumn{13}{|c|}{ Cell L18/L26 - target $p H 8$} \\
\hline Avg. & 3 & 25 & -4.19 & 0.27 & -3.99 & 0.05 & -2.95 & 0.06 & -3.04 & 0.09 & na & na \\
\hline Avg. & 8 & 25 & -4.41 & 0.43 & -4.06 & 0.06 & -2.97 & 0.01 & -3.74 & 0.01 & -3.11 & 0.02 \\
\hline Avg. & 13 & 25 & -4.71 & 0.67 & -4.10 & 0.02 & -2.94 & 0.02 & -3.36 & 0.00 & na & na \\
\hline Avg. & 14 & 25 & -3.99 & 0.00 & -4.21 & 0.11 & -2.94 & 0.02 & -3.23 & 0.03 & -3.36 & 0.03 \\
\hline \multicolumn{13}{|c|}{ Cell L09/L29-target $p H 9$} \\
\hline Avg. & 3 & 25 & -3.85 & 0.00 & -4.71 & 0.02 & -2.14 & 0.42 & -2.77 & 0.08 & na & na \\
\hline Avg. & 8 & 25 & -4.10 & 0.21 & -4.53 & 0.11 & -2.94 & 0.01 & -3.21 & 0.03 & -3.72 & 0.01 \\
\hline Avg. & 13 & 25 & -3.61 & 0.00 & -4.47 & 0.09 & -2.92 & 0.01 & -3.58 & 0.26 & na & na \\
\hline Avg. & 14 & 25 & -3.68 & 0.13 & -4.59 & 0.29 & -2.93 & 0.02 & -3.18 & 0.34 & -3.88 & 0.18 \\
\hline \multicolumn{13}{|c|}{ Cell L25L22 - target $p H 10$} \\
\hline Avg. & 3 & 25 & -3.86 & 0.42 & -4.72 & 0.46 & -2.17 & 0.31 & -2.56 & 0.15 & na & na \\
\hline Avg. & 8 & 25 & -4.06 & 0.17 & -4.16 & 0.12 & -2.93 & 0.02 & -3.32 & 0.04 & -3.63 & 0.02 \\
\hline Avg. & 13 & 25 & -4.16 & 0.06 & -4.20 & 0.30 & -2.95 & 0.01 & -3.40 & 0.04 & na & na \\
\hline Avg. & 14 & 25 & -4.04 & 0.19 & -4.17 & 0.31 & -2.89 & 0.06 & -3.29 & 0.16 & -3.94 & 0.42 \\
\hline \multicolumn{13}{|c|}{ Cell L15/L36 - target $p H 11$} \\
\hline Avg. & 3 & 25 & -3.20 & 0.33 & -2.98 & 0.21 & -1.91 & 0.03 & -2.47 & 0.15 & na & na \\
\hline Avg. & 8 & 25 & -3.34 & 0.35 & -3.14 & 0.21 & -2.42 & 0.06 & -2.91 & 0.09 & -2.19 & 0.40 \\
\hline Avg. & 13 & 25 & -3.18 & 0.16 & -3.02 & 0.09 & -2.70 & 0.24 & -2.87 & 0.04 & na & na \\
\hline Avg. & 14 & 25 & -3.32 & 0.24 & -3.12 & 0.14 & -2.74 & 0.21 & -2.85 & 0.14 & -2.14 & 0.52 \\
\hline \multicolumn{13}{|c|}{ Cell L10/L30-target $p H 7$} \\
\hline Avg. & 3 & 40 & -3.73 & 0.01 & na & 0.00 & -2.97 & 0.04 & -2.89 & 0.01 & na & na \\
\hline Avg. & 8 & 40 & -3.77 & 0.03 & -4.32 & 0.02 & -2.94 & 0.00 & -2.86 & 0.19 & -2.95 & 0.08 \\
\hline Avg. & 13 & 40 & -3.91 & 0.03 & -4.35 & 0.05 & -2.92 & 0.00 & -3.21 & 0.04 & na & na \\
\hline
\end{tabular}


WSRC-TR-2005-00124

Revision 0

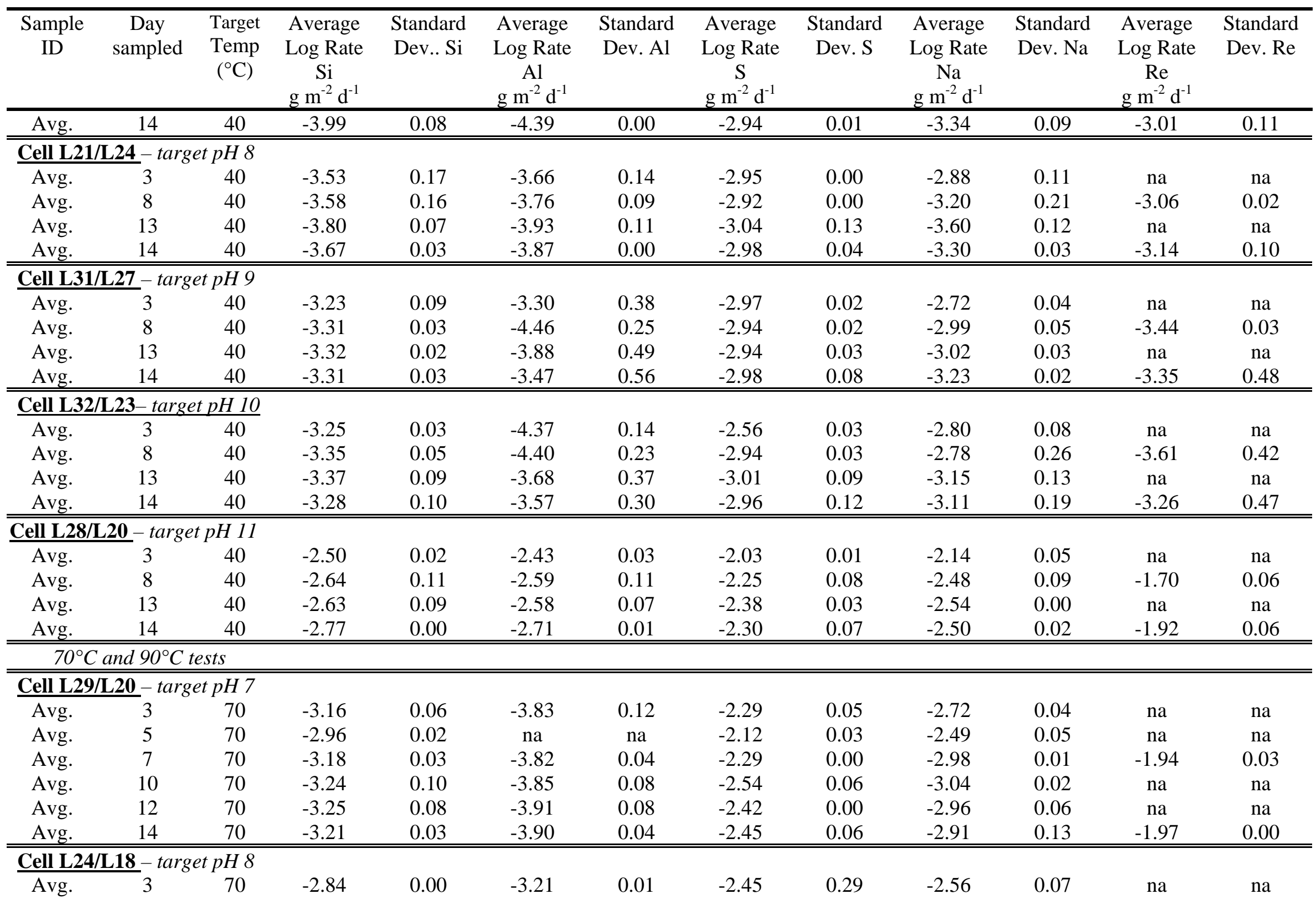


WSRC-TR-2005-00124

Revision 0

\begin{tabular}{|c|c|c|c|c|c|c|c|c|c|c|c|c|}
\hline $\begin{array}{c}\text { Sample } \\
\text { ID }\end{array}$ & $\begin{array}{c}\text { Day } \\
\text { sampled }\end{array}$ & $\begin{array}{c}\text { Target } \\
\text { Temp } \\
\left({ }^{\circ} \mathrm{C}\right)\end{array}$ & $\begin{array}{c}\text { Average } \\
\text { Log Rate } \\
\text { Si } \\
\mathrm{g} \mathrm{m}^{-2} \mathrm{~d}^{-1}\end{array}$ & $\begin{array}{l}\text { Standard } \\
\text { Dev.. Si }\end{array}$ & $\begin{array}{c}\text { Average } \\
\text { Log Rate } \\
\text { Al } \\
\mathrm{g} \mathrm{m}^{-2} \mathrm{~d}^{-1}\end{array}$ & $\begin{array}{c}\text { Standard } \\
\text { Dev. Al }\end{array}$ & $\begin{array}{c}\text { Average } \\
\text { Log Rate } \\
\mathrm{S} \\
\mathrm{g} \mathrm{m}^{-2} \mathrm{~d}^{-1} \\
\end{array}$ & $\begin{array}{c}\text { Standard } \\
\text { Dev. S }\end{array}$ & $\begin{array}{c}\text { Average } \\
\text { Log Rate } \\
\mathrm{Na} \\
\mathrm{g} \mathrm{m}^{-2} \mathrm{~d}^{-1}\end{array}$ & $\begin{array}{l}\text { Standard } \\
\text { Dev. Na }\end{array}$ & $\begin{array}{c}\text { Average } \\
\text { Log Rate } \\
\text { Re } \\
\text { g m }^{-2} \mathrm{~d}^{-1}\end{array}$ & $\begin{array}{l}\text { Standard } \\
\text { Dev. Re }\end{array}$ \\
\hline Avg. & 5 & 70 & -3.07 & 0.01 & -3.41 & 0.01 & -2.76 & 0.26 & -2.66 & 0.21 & na & na \\
\hline Avg. & 7 & 70 & -3.18 & 0.01 & -3.51 & 0.00 & -2.64 & 0.08 & -2.95 & 0.02 & -2.27 & 0.07 \\
\hline Avg. & 10 & 70 & -3.13 & 0.05 & -3.45 & 0.03 & -2.50 & 0.08 & -2.91 & 0.06 & na & na \\
\hline Avg. & 12 & 70 & -3.19 & 0.05 & -3.50 & 0.04 & -2.78 & 0.22 & -2.99 & 0.06 & na & na \\
\hline Avg. & 14 & 70 & -3.90 & 0.03 & na & na & -2.61 & na & -3.00 & 0.01 & -2.17 & 0.07 \\
\hline \multicolumn{13}{|c|}{ Cell L33L25 - target $p H 9$} \\
\hline Avg. & 3 & 70 & -2.73 & 0.01 & -3.83 & 0.29 & -2.65 & 0.02 & -2.40 & 0.02 & na & na \\
\hline Avg. & 5 & 70 & -2.92 & 0.03 & -4.29 & 0.31 & -2.95 & 0.04 & -2.59 & 0.07 & na & na \\
\hline Avg. & 7 & 70 & -2.90 & 0.00 & -4.32 & 0.16 & -2.88 & 0.00 & -2.64 & 0.01 & na & na \\
\hline Avg. & 10 & 70 & -2.92 & 0.03 & -3.98 & 0.58 & -2.94 & 0.06 & -2.61 & 0.07 & na & na \\
\hline Avg. & 12 & 70 & -2.93 & 0.03 & -3.56 & 0.01 & -2.98 & 0.02 & -2.72 & 0.05 & -2.59 & na \\
\hline Avg. & 14 & 70 & -2.84 & na & -3.30 & na & -2.88 & na & -2.66 & na & -2.59 & na \\
\hline \multicolumn{13}{|c|}{ Cell L14/L32 - target $p H 10$} \\
\hline Avg. & 3 & 70 & -2.77 & 0.01 & -3.50 & 0.03 & -2.63 & 0.03 & -2.54 & 0.00 & na & na \\
\hline Avg. & 5 & 70 & -2.87 & 0.03 & -4.06 & 0.05 & -2.94 & 0.03 & -2.67 & 0.05 & na & na \\
\hline Avg. & 7 & 70 & -2.89 & 0.05 & -4.10 & 0.28 & -2.92 & 0.01 & -2.62 & 0.06 & na & na \\
\hline Avg. & 10 & 70 & -2.89 & 0.04 & -4.28 & 0.07 & -2.92 & 0.00 & -2.61 & 0.05 & na & na \\
\hline Avg. & 12 & 70 & -2.85 & 0.03 & -4.07 & 0.28 & -2.95 & 0.02 & -2.54 & 0.09 & na & na \\
\hline Avg. & 14 & 70 & -2.85 & 0.02 & -4.05 & 0.04 & -2.93 & 0.04 & -2.57 & 0.01 & -3.02 & 0.06 \\
\hline \multicolumn{13}{|c|}{ Cell L13/L30 - target $p H 11$} \\
\hline Avg. & 3 & 70 & -2.02 & 0.01 & -1.98 & 0.01 & -1.61 & 0.02 & -1.79 & 0.04 & na & na \\
\hline Avg. & 5 & 70 & -2.19 & 0.01 & -2.14 & 0.01 & -1.91 & 0.01 & -2.08 & 0.01 & na & na \\
\hline Avg. & 7 & 70 & -2.33 & 0.06 & -2.29 & 0.06 & -2.02 & 0.04 & -2.29 & 0.04 & -1.47 & 0.01 \\
\hline Avg. & 10 & 70 & -2.27 & 0.01 & -2.23 & 0.01 & -1.96 & 0.02 & -2.34 & 0.02 & na & na \\
\hline Avg. & 12 & 70 & -2.30 & 0.02 & -2.26 & 0.02 & -2.13 & 0.16 & -2.46 & 0.03 & na & na \\
\hline Avg. & 14 & 70 & -2.38 & 0.02 & -2.34 & 0.01 & -2.22 & 0.08 & -2.54 & 0.04 & -1.69 & 0.07 \\
\hline \multicolumn{13}{|c|}{ Cell L19/L09-target $p H 7$} \\
\hline Avg. & 3 & 90 & -2.68 & 0.06 & -3.59 & 0.03 & -1.97 & 0.08 & -2.33 & 0.01 & -1.37 & na \\
\hline Avg. & 5 & 90 & -2.67 & 0.06 & -4.61 & 0.77 & -1.96 & 0.07 & -2.44 & 0.26 & -1.33 & na \\
\hline Avg. & 7 & 90 & -2.76 & 0.05 & -3.56 & 0.07 & -2.41 & 0.01 & -2.60 & 0.02 & -1.82 & na \\
\hline Avg. & 10 & 90 & -2.82 & 0.04 & -3.71 & 0.02 & -2.59 & 0.03 & -2.65 & 0.00 & -1.96 & na \\
\hline
\end{tabular}


WSRC-TR-2005-00124

Revision 0

\begin{tabular}{|c|c|c|c|c|c|c|c|c|c|c|c|c|}
\hline $\begin{array}{c}\text { Sample } \\
\text { ID }\end{array}$ & $\begin{array}{c}\text { Day } \\
\text { sampled }\end{array}$ & $\begin{array}{c}\text { Target } \\
\text { Temp } \\
\left({ }^{\circ} \mathrm{C}\right)\end{array}$ & $\begin{array}{c}\text { Average } \\
\text { Log Rate } \\
\text { Si } \\
\mathrm{g} \mathrm{m}^{-2} \mathrm{~d}^{-1} \\
\end{array}$ & $\begin{array}{l}\text { Standard } \\
\text { Dev.. Si }\end{array}$ & $\begin{array}{c}\text { Average } \\
\text { Log Rate } \\
\text { Al } \\
\mathrm{g} \mathrm{m}^{-2} \mathrm{~d}^{-1}\end{array}$ & $\begin{array}{c}\text { Standard } \\
\text { Dev. Al }\end{array}$ & $\begin{array}{c}\text { Average } \\
\text { Log Rate } \\
\mathrm{S} \\
\mathrm{g} \mathrm{m}^{-2} \mathrm{~d}^{-1} \\
\end{array}$ & $\begin{array}{l}\text { Standard } \\
\text { Dev. S }\end{array}$ & $\begin{array}{c}\text { Average } \\
\text { Log Rate } \\
\mathrm{Na} \\
\mathrm{g} \mathrm{m}^{-2} \mathrm{~d}^{-1}\end{array}$ & $\begin{array}{l}\text { Standard } \\
\text { Dev. Na }\end{array}$ & $\begin{array}{c}\text { Average } \\
\text { Log Rate } \\
\text { Re } \\
\mathrm{g} \mathrm{m}^{-2} \mathrm{~d}^{-1}\end{array}$ & $\begin{array}{l}\text { Standard } \\
\text { Dev. Re }\end{array}$ \\
\hline Avg. & 12 & 90 & -2.79 & 0.00 & -3.74 & 0.00 & -2.53 & 0.05 & -2.61 & 0.03 & -1.97 & na \\
\hline Avg. & 14 & 90 & -2.80 & 0.10 & -3.77 & 0.07 & -2.81 & 0.15 & -2.64 & 0.09 & -2.12 & 0.14 \\
\hline \multicolumn{13}{|c|}{ Cell L27/L10 - target $p H 8$} \\
\hline Avg. & 3 & 90 & -2.66 & 0.00 & -3.14 & 0.00 & -2.12 & 0.08 & -2.37 & 0.04 & na & na \\
\hline Avg. & 5 & 90 & -2.76 & 0.04 & -3.29 & 0.03 & -2.22 & 0.00 & -2.47 & 0.06 & na & na \\
\hline Avg. & 7 & 90 & -2.78 & 0.02 & -3.34 & 0.01 & -2.23 & 0.00 & -2.53 & 0.01 & -1.75 & 0.01 \\
\hline Avg. & 10 & 90 & -2.74 & 0.04 & -3.33 & 0.03 & -2.36 & 0.01 & -2.57 & 0.03 & na & na \\
\hline Avg. & 12 & 90 & -2.79 & 0.00 & -3.39 & 0.01 & -2.74 & 0.33 & -2.64 & 0.02 & na & na \\
\hline Avg. & 14 & 90 & -2.92 & 0.05 & na & na & -2.45 & 0.07 & -2.62 & 0.04 & -1.90 & 0.04 \\
\hline \multicolumn{13}{|c|}{ Cell L31/L15- target $p H 9$} \\
\hline Avg. & 3 & 90 & -2.41 & na & -2.82 & na & -2.14 & na & -2.09 & na & na & na \\
\hline Avg. & 5 & 90 & -2.78 & 0.02 & -4.56 & 0.15 & -2.68 & 0.36 & -2.36 & 0.04 & na & na \\
\hline Avg. & 7 & 90 & -2.79 & 0.05 & -5.06 & 0.91 & -2.96 & 0.07 & -2.43 & 0.07 & -2.76 & 0.20 \\
\hline Avg. & 10 & 90 & -2.86 & 0.11 & -4.49 & na & -3.26 & 0.00 & -2.57 & 0.30 & na & na \\
\hline Avg. & 12 & 90 & -2.79 & 0.09 & na & na & -2.79 & 0.36 & -2.53 & 0.08 & na & na \\
\hline Avg. & 14 & 90 & -2.86 & 0.02 & -4.69 & 0.34 & -2.67 & 0.38 & -2.49 & 0.02 & -1.94 & 0.06 \\
\hline \multicolumn{13}{|c|}{ Cell L26/L23 - target $p H 10$} \\
\hline Avg. & 3 & 90 & -2.30 & 0.17 & -2.62 & 0.55 & -1.82 & 1.17 & -1.81 & 0.47 & na & na \\
\hline Avg. & 5 & 90 & -2.58 & 0.17 & -3.57 & 1.16 & -2.92 & 0.03 & -2.25 & 0.11 & na & na \\
\hline Avg. & 7 & 90 & -2.72 & 0.00 & -3.99 & 0.12 & -2.95 & 0.05 & -2.33 & 0.02 & -2.66 & 0.21 \\
\hline Avg. & 10 & 90 & -2.67 & 0.06 & -3.98 & 0.39 & -2.95 & 0.00 & -2.26 & 0.11 & na & na \\
\hline Avg. & 12 & 90 & -2.75 & 0.05 & -4.56 & 0.49 & -2.74 & 0.26 & -2.37 & 0.08 & na & na \\
\hline Avg. & 14 & 90 & -2.73 & 0.05 & -4.36 & 0.18 & -2.60 & 0.50 & -2.33 & 0.07 & -2.16 & 0.59 \\
\hline \multicolumn{13}{|c|}{ Cell L34/L21 - target $p H 11$} \\
\hline Avg. & 3 & 90 & -1.91 & 0.01 & -1.87 & 0.01 & -1.57 & 0.16 & -1.57 & 0.06 & na & na \\
\hline Avg. & 5 & 90 & -2.04 & 0.06 & -2.00 & 0.05 & -1.75 & 0.09 & -1.82 & 0.06 & na & na \\
\hline Avg. & 7 & 90 & -2.08 & 0.07 & -2.04 & 0.06 & -1.75 & 0.06 & -2.02 & 0.07 & -1.15 & 0.04 \\
\hline Avg. & 10 & 90 & -2.12 & 0.01 & -2.08 & 0.01 & -2.01 & 0.13 & -2.30 & 0.09 & na & na \\
\hline Avg. & 12 & 90 & -2.24 & 0.02 & -2.21 & 0.02 & -2.38 & 0.28 & -2.45 & 0.01 & na & na \\
\hline Avg. & 14 & 90 & -2.20 & 0.02 & -2.17 & 0.02 & -2.30 & 0.13 & -2.39 & 0.01 & -1.83 & 0.17 \\
\hline
\end{tabular}




\section{APPENDIX B. SPFT TEST DATA OF SBW 1173 BED PRODUCT}

Table B1. Experimental conditions and SPFT data for tests with SBW 1173 bed product (all tests performed at $0.2 \mathrm{~mL} / \mathrm{min}$ flow rate)

\begin{tabular}{|c|c|c|c|c|c|c|c|c|c|c|c|c|c|}
\hline $\begin{array}{c}\text { Sample } \\
\text { ID }\end{array}$ & $\begin{array}{c}\text { Day } \\
\text { sampled }\end{array}$ & $\begin{array}{l}\text { Temp } \\
\left({ }^{\circ} \mathrm{C}\right)\end{array}$ & $\mathrm{pH}$ & $\begin{array}{c}\mathrm{C}_{\mathrm{Si}} \\
\mathrm{mg} \mathrm{L}^{-1}\end{array}$ & $\begin{array}{r}\mathrm{C}_{\mathrm{Al}} \\
\mathrm{mg} \mathrm{L}^{-1} \\
\end{array}$ & $\begin{array}{c}\mathrm{C}_{\mathrm{S}} \\
\mathrm{mg} \mathrm{L}^{-1} \\
\end{array}$ & $\begin{array}{c}\mathrm{C}_{\mathrm{Na}} \\
\mathrm{mg} \mathrm{L}^{-1}\end{array}$ & $\begin{array}{c}\mathrm{C}_{\mathrm{Re}} \\
\mu \mathrm{g} \mathrm{L}^{-1}\end{array}$ & $\begin{array}{l}\text { Rate Si } \\
\mathrm{g} \mathrm{m}^{-2} \mathrm{~d}^{-1}\end{array}$ & $\begin{array}{l}\text { Rate Al } \\
\mathrm{g} \mathrm{m}^{-2} \mathrm{~d}^{-1}\end{array}$ & $\begin{array}{c}\text { Rate S } \\
\mathrm{g} \mathrm{m}^{-2} \mathrm{~d}^{-1}\end{array}$ & $\begin{array}{l}\text { Rate Na } \\
\mathrm{g} \mathrm{m}^{-2} \mathrm{~d}^{-1}\end{array}$ & $\begin{array}{l}\text { Rate Re } \\
\mathrm{g} \mathrm{m}^{-2} \mathrm{~d}^{-1}\end{array}$ \\
\hline \multicolumn{14}{|c|}{$70^{\circ} \mathrm{C}$ and $90^{\circ} \mathrm{C}$ tests } \\
\hline L15-3-1 & 4 & 69.9 & 7.51 & 1.17 & 0.391 & 0.05 & 12 & na & 7.28E-04 & 1.69E-04 & 1.35E-02 & $1.07 \mathrm{E}-02$ & na \\
\hline L15-3-2 & 6 & 69.9 & 7.83 & 1.1 & 0.282 & 0.05 & 6.32 & 0.06 & $6.60 \mathrm{E}-04$ & 1.27E-04 & $1.30 \mathrm{E}-02$ & $5.43 \mathrm{E}-03$ & 8.97E-05 \\
\hline L15-3-3 & 8 & 69.9 & 7.55 & na & na & na & na & na & na & na & na & na & na \\
\hline L15-3-4 & 11 & 70.8 & 7.84 & 1.25 & 0.228 & 0.05 & 4.17 & na & 8.01E-04 & 5.82E-05 & 1.39E-02 & 3.81E-03 & na \\
\hline L15-3-5 & 14 & 70.2 & 7.75 & 1.28 & 0.207 & 0.05 & 3.07 & 0.04 & 8.61E-04 & 9.64E-05 & $1.46 \mathrm{E}-02$ & 2.93E-03 & 5.03E-05 \\
\hline \multicolumn{14}{|c|}{ Cell L18-target $p H 7$} \\
\hline L18-3-1 & 4 & 69.9 & 7.47 & 1.77 & 0.536 & 0.05 & 14.7 & na & $1.15 \mathrm{E}-03$ & 2.59E-04 & $1.41 \mathrm{E}-02$ & $1.37 \mathrm{E}-02$ & na \\
\hline L18-3-2 & 6 & 69.9 & 7.91 & 1.6 & 0.376 & 0.05 & 4.86 & 0.05 & $1.02 \mathrm{E}-03$ & $1.86 \mathrm{E}-04$ & 1.37E-02 & $4.40 \mathrm{E}-03$ & 7.11E-05 \\
\hline L18-3-3 & 8 & 69.9 & 7.55 & na & na & na & na & na & na & na & na & na & na \\
\hline L18-3-4 & 11 & 70.8 & 7.81 & 1.52 & 0.3 & 0.05 & 4.6 & na & $1.15 \mathrm{E}-03$ & $1.16 \mathrm{E}-04$ & 1.63E-02 & $4.94 \mathrm{E}-03$ & na \\
\hline L18-3-5 & 14 & 70.2 & 7.72 & 1.5 & 0.269 & 0.05 & 2.92 & 0.04 & $1.11 \mathrm{E}-03$ & $1.46 \mathrm{E}-04$ & $1.60 \mathrm{E}-02$ & $3.06 \mathrm{E}-03$ & 5.52E-05 \\
\hline \multicolumn{14}{|c|}{ Cell L20-target $p H 8$} \\
\hline L20-3-1 & 4 & 69.9 & 7.78 & 1.31 & 0.813 & 0.05 & 11.5 & na & 8.57E-04 & 4.41E-04 & $1.42 \mathrm{E}-02$ & $1.08 \mathrm{E}-02$ & na \\
\hline L20-3-2 & 6 & 69.9 & 8.39 & 1.21 & 0.902 & 0.05 & 10.7 & 0.04 & $6.56 \mathrm{E}-04$ & 4.10E-04 & 1.17E-02 & 8.34E-03 & 4.05E-05 \\
\hline L20-3-3 & 8 & 69.9 & 7.97 & na & na & na & na & na & na & na & na & na & na \\
\hline L20-3-4 & 11 & 70.8 & 8.21 & 1.3 & 0.613 & 0.05 & 3.43 & na & $9.46 \mathrm{E}-04$ & 3.66E-04 & $1.57 \mathrm{E}-02$ & $3.55 \mathrm{E}-03$ & na \\
\hline L20-3-5 & 14 & 70.2 & 8.06 & 1.39 & 0.572 & 0.05 & 4.64 & 0.05 & $1.01 \mathrm{E}-03$ & 3.31E-04 & $1.57 \mathrm{E}-02$ & 4.79E-03 & 8.11E-05 \\
\hline \multicolumn{14}{|c|}{ Cell L22-target $p H 8$} \\
\hline L22-3-1 & 4 & 69.9 & 7.85 & 1.69 & 1.14 & 0.05 & 11.4 & na & $9.80 \mathrm{E}-04$ & 5.56E-04 & $1.25 \mathrm{E}-02$ & $9.47 \mathrm{E}-03$ & na \\
\hline L22-3-2 & 6 & 69.9 & 8.38 & 1.42 & 0.819 & 0.05 & 7.7 & 0.04 & 7.97E-04 & 3.83E-04 & $1.21 \mathrm{E}-02$ & 6.19E-03 & 4.19E-05 \\
\hline L22-3-3 & 8 & 69.9 & 8 & na & na & na & na & na & na & na & na & na & na \\
\hline L22-3-4 & 11 & 70.8 & 8.32 & 1.13 & 0.529 & 0.05 & 5.9 & na & 7.52E-04 & 2.86E-04 & $1.44 \mathrm{E}-02$ & $5.62 \mathrm{E}-03$ & \\
\hline L22-3-5 & 14 & 70.2 & 8.11 & 1.46 & 0.787 & 0.05 & 5.47 & 0.04 & $9.91 \mathrm{E}-04$ & 4.38E-04 & $1.47 \mathrm{E}-02$ & $5.30 \mathrm{E}-03$ & 5.07E-05 \\
\hline \multicolumn{14}{|c|}{ 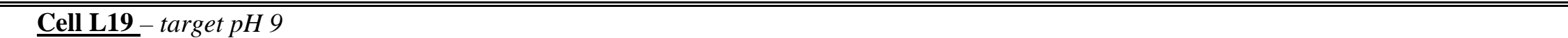 } \\
\hline L19-3-1 & 4 & 69.9 & 8.49 & 2.21 & 3.3 & 0.05 & 9.19 & na & $1.57 \mathrm{E}-03$ & 2.01E-03 & $1.52 \mathrm{E}-02$ & $9.28 \mathrm{E}-03$ & na \\
\hline L19-3-2 & 6 & 69.9 & 9.06 & 1.59 & 0.547 & 0.05 & 6.05 & 0.06 & $1.11 \mathrm{E}-03$ & 3.15E-04 & $1.50 \mathrm{E}-02$ & $6.02 \mathrm{E}-03$ & $1.04 \mathrm{E}-04$ \\
\hline L19-3-3 & 8 & 69.9 & 8.65 & na & na & na & na & na & na & na & na & na & na \\
\hline
\end{tabular}


WSRC-TR-2005-00124

Revision 0

\begin{tabular}{|c|c|c|c|c|c|c|c|c|c|c|c|c|c|}
\hline $\begin{array}{l}\text { Sample } \\
\text { ID }\end{array}$ & $\begin{array}{c}\text { Day } \\
\text { sampled }\end{array}$ & $\begin{array}{l}\text { Temp } \\
\left({ }^{\circ} \mathrm{C}\right)\end{array}$ & $\mathrm{pH}$ & $\begin{array}{c}\mathrm{C}_{\mathrm{Si}} \\
\mathrm{mg} \mathrm{L}^{-1}\end{array}$ & $\begin{array}{c}\mathrm{C}_{\mathrm{Al}} \\
\mathrm{mg} \mathrm{L}^{-1}\end{array}$ & $\begin{array}{c}\mathrm{C}_{\mathrm{S}} \\
\mathrm{mg} \mathrm{L}^{-1}\end{array}$ & $\begin{array}{c}\mathrm{C}_{\mathrm{Na}} \\
\mathrm{mg} \mathrm{L}^{-1}\end{array}$ & $\begin{array}{c}\mathrm{C}_{\mathrm{Re}} \\
\mu \mathrm{g} \mathrm{L}^{-1}\end{array}$ & $\begin{array}{l}\text { Rate Si } \\
\mathrm{g} \mathrm{m}^{-2} \mathrm{~d}^{-1}\end{array}$ & $\begin{array}{l}\text { Rate Al } \\
\mathrm{g} \mathrm{m}^{-2} \mathrm{~d}^{-1}\end{array}$ & $\begin{array}{c}\text { Rate S } \\
\mathrm{g} \mathrm{m}^{-2} \mathrm{~d}^{-1}\end{array}$ & $\begin{array}{l}\text { Rate Na } \\
\mathrm{g} \mathrm{m}^{-2} \mathrm{~d}^{-1}\end{array}$ & $\begin{array}{l}\text { Rate Re } \\
\mathrm{g} \mathrm{m}^{-2} \mathrm{~d}^{-1}\end{array}$ \\
\hline L19-3-4 & 11 & 70.8 & 8.96 & 1.37 & 0.861 & 0.05 & 4.78 & na & 9.69E-04 & $5.05 \mathrm{E}-04$ & $1.52 \mathrm{E}-02$ & 4.79E-03 & na \\
\hline L19-3-5 & 14 & 70.2 & 8.84 & 1.66 & 1.78 & 0.05 & 2.62 & 0.04 & $1.20 \mathrm{E}-03$ & $1.12 \mathrm{E}-03$ & $1.55 \mathrm{E}-02$ & 2.71E-03 & 1.07E-04 \\
\hline \multicolumn{14}{|c|}{ Cell L21 - target pH 9} \\
\hline L21-3-1 & 4 & 69.9 & 8.51 & 1.89 & 2.63 & 0.05 & 8.55 & na & $1.08 \mathrm{E}-03$ & 1.29E-03 & 1.23E-02 & 6.97E-03 & na \\
\hline L21-3-2 & 6 & 69.9 & 9.1 & 1.87 & 2.73 & 0.05 & 6.79 & 0.05 & $1.10 \mathrm{E}-03$ & 1.37E-03 & $1.26 \mathrm{E}-02$ & $5.66 \mathrm{E}-03$ & 6.52E-05 \\
\hline L21-3-3 & 8 & 69.9 & 8.67 & na & na & na & na & na & na & na & na & na & na \\
\hline L21-3-4 & 11 & 70.8 & 9.02 & 1.48 & 1.83 & 0.05 & 4.98 & na & 7.27E-04 & 7.63E-04 & $1.05 \mathrm{E}-02$ & $3.47 \mathrm{E}-03$ & na \\
\hline L21-3-5 & 14 & 70.2 & 8.88 & 1.9 & 2.13 & 0.05 & 4.77 & 0.05 & $1.12 \mathrm{E}-03$ & $1.09 \mathrm{E}-03$ & $1.26 \mathrm{E}-02$ & $4.01 \mathrm{E}-03$ & $1.09 \mathrm{E}-04$ \\
\hline \multicolumn{14}{|c|}{ "Cell L09-target $p H 10$} \\
\hline L09-3-1 & 4 & 69.9 & 9.23 & 2.76 & 2.85 & 0.05 & 7.91 & na & $1.78 \mathrm{E}-03$ & $1.58 \mathrm{E}-03$ & 1.39E-02 & 6.76E-03 & na \\
\hline L09-3-2 & 6 & 69.9 & 9.9 & 2.46 & 1.75 & 0.05 & 11.2 & 0.05 & 1.84E-03 & $1.26 \mathrm{E}-03$ & 2.57E-03 & 9.32E-03 & 8.44E-05 \\
\hline L09-3-3 & 8 & 69.9 & 9.72 & na & na & na & na & na & na & na & na & na & na \\
\hline L09-3-4 & 11 & 70.8 & 9.78 & 1.93 & 0.556 & 0.05 & 2.85 & na & $1.04 \mathrm{E}-03$ & 2.79E-04 & $1.86 \mathrm{E}-03$ & 1.69E-03 & na \\
\hline L09-3-5 & 14 & 70.2 & 9.54 & 2.13 & 0.835 & 0.05 & 4.83 & 0.05 & 1.39E-03 & 5.11E-04 & 2.24E-03 & 3.49E-03 & 7.37E-05 \\
\hline \multicolumn{14}{|c|}{ Cell L14-target $p H 10$} \\
\hline L14-3-1 & 4 & 69.9 & 9.28 & 2.75 & 2.69 & 0.05 & 8.17 & na & 1.63E-03 & 1.37E-03 & $1.28 \mathrm{E}-02$ & $6.44 \mathrm{E}-03$ & na \\
\hline L14-3-2 & 6 & 69.9 & 9.94 & 3.01 & 1.65 & 0.05 & 5.34 & 0.07 & 1.77E-03 & 8.27E-04 & $1.26 \mathrm{E}-02$ & 4.45E-03 & 1.09E-04 \\
\hline L14-3-3 & 8 & 69.9 & 9.76 & na & na & na & na & na & na & na & na & na & na \\
\hline L14-3-4 & 11 & 70.8 & 9.86 & 2.36 & 0.855 & 0.05 & 5.16 & na & $1.54 \mathrm{E}-03$ & 4.72E-04 & $1.41 \mathrm{E}-02$ & 4.80E-03 & na \\
\hline L14-3-5 & 14 & 70.2 & 9.62 & 2.69 & 0.858 & 0.05 & 4.46 & 0.05 & 1.63E-03 & 4.36E-04 & 1.31E-02 & 3.85E-03 & 6.78E-05 \\
\hline \multicolumn{14}{|c|}{ Cell L13-target $p H 11$} \\
\hline L13-3-1 & 4 & 69.9 & 11.08 & 10.5 & 9.43 & 0.05 & 7.2 & na & 5.47E-03 & 4.25E-03 & $1.12 \mathrm{E}-02$ & 5.33E-03 & na \\
\hline L13-3-2 & 6 & 69.9 & 11.64 & 11.4 & 9.97 & 0.05 & 8.96 & 0.11 & $6.16 \mathrm{E}-03$ & 4.66E-03 & 1.16E-02 & 6.90E-03 & $1.80 \mathrm{E}-04$ \\
\hline L13-3-3 & 8 & 69.9 & 11.44 & 9.86 & 8.54 & 0.05 & 8 & na & 6.08E-03 & 4.56E-03 & 1.32E-02 & 7.06E-03 & na \\
\hline L13-3-4 & 11 & 70.8 & 11.58 & 11.8 & 9.08 & 0.05 & 10.2 & 0.09 & 7.08E-03 & 4.71E-03 & 1.29E-02 & 8.73E-03 & 2.00E-04 \\
\hline L13-3-5 & 14 & 70.2 & na & na & na & na & na & na & na & na & na & na & na \\
\hline \multicolumn{14}{|c|}{ Cell L10-target $p H 11$} \\
\hline L10-3-1 & 4 & 69.9 & 11.17 & 11.5 & 10.7 & 0.05 & 10.2 & na & 6.81E-03 & $5.48 \mathrm{E}-03$ & 1.27E-02 & 8.60E-03 & na \\
\hline L10-3-2 & 6 & 69.9 & 11.71 & 10.7 & 9.59 & 0.05 & 8.41 & 0.09 & 6.61E-03 & 5.12E-03 & 1.33E-02 & 7.39E-03 & $1.60 \mathrm{E}-04$ \\
\hline L10-3-3 & 8 & 69.9 & 11.48 & 8.61 & 7.68 & 0.05 & 8.08 & na & 5.03E-03 & 3.89E-03 & $1.25 \mathrm{E}-02$ & 6.75E-03 & na \\
\hline L10-3-4 & 11 & 70.8 & 11.7 & 10.4 & 8.06 & 0.05 & 10 & 0.09 & 7.89E-03 & $5.28 \mathrm{E}-03$ & 1.63E-02 & $1.08 \mathrm{E}-02$ & 2.53E-04 \\
\hline L10-3-5 & 14 & 70.2 & na & na & na & na & na & na & na & na & na & na & na \\
\hline
\end{tabular}


WSRC-TR-2005-00124

Revision 0

\begin{tabular}{|c|c|c|c|c|c|c|c|c|c|c|c|c|c|}
\hline $\begin{array}{c}\text { Sample } \\
\text { ID }\end{array}$ & $\begin{array}{c}\text { Day } \\
\text { sampled }\end{array}$ & $\begin{array}{l}\text { Temp } \\
\left({ }^{\circ} \mathrm{C}\right)\end{array}$ & $\mathrm{pH}$ & $\begin{array}{c}\mathrm{C}_{\mathrm{Si}} \\
\mathrm{mg} \mathrm{L}^{-1}\end{array}$ & $\begin{array}{c}\mathrm{C}_{\mathrm{Al}} \\
\mathrm{mg} \mathrm{L}^{-1}\end{array}$ & $\begin{array}{c}\mathrm{C}_{\mathrm{S}} \\
\mathrm{mg} \mathrm{L}^{-1}\end{array}$ & $\begin{array}{c}\mathrm{C}_{\mathrm{Na}} \\
\mathrm{mg} \mathrm{L}^{-1}\end{array}$ & $\begin{array}{c}\mathrm{C}_{\mathrm{Re}} \\
\mu \mathrm{g} \mathrm{L}^{-1}\end{array}$ & $\begin{array}{l}\text { Rate Si } \\
\mathrm{g} \mathrm{m}^{-2} \mathrm{~d}^{-1}\end{array}$ & $\begin{array}{l}\text { Rate Al } \\
\mathrm{g} \mathrm{m}^{-2} \mathrm{~d}^{-1}\end{array}$ & $\begin{array}{c}\text { Rate S } \\
\mathrm{g} \mathrm{m}^{-2} \mathrm{~d}^{-1}\end{array}$ & $\begin{array}{l}\text { Rate Na } \\
\mathrm{g} \mathrm{m}^{-2} \mathrm{~d}^{-1}\end{array}$ & $\begin{array}{l}\text { Rate Re } \\
\mathrm{g} \mathrm{m}^{-2} \mathrm{~d}^{-1}\end{array}$ \\
\hline \multicolumn{14}{|c|}{ Cell L23-target $p H 7$} \\
\hline L23-3-1 & 4 & 91 & 7.56 & 2.84 & 0.431 & 0.05 & 10.8 & na & $1.70 \mathrm{E}-03$ & $1.82 \mathrm{E}-04$ & 1.29E-02 & $9.24 \mathrm{E}-03$ & na \\
\hline L23-3-2 & 6 & 90.3 & 8.06 & 3.05 & 0.384 & 0.05 & 9.41 & 0.06 & 1.73E-03 & $1.69 \mathrm{E}-04$ & $1.22 \mathrm{E}-02$ & 7.63E-03 & $8.45 \mathrm{E}-05$ \\
\hline L23-3-3 & 8 & 91 & 7.77 & na & na & na & na & na & na & na & na & na & na \\
\hline L23-3-4 & 11 & 91.6 & 8.08 & 2.97 & 0.295 & 0.05 & 4.88 & na & $1.75 \mathrm{E}-03$ & 8.79E-05 & 1.27E-02 & 4.10E-03 & na \\
\hline L23-3-5 & 14 & 91.3 & 7.97 & 3.18 & 0.315 & 0.05 & 4.87 & 0.06 & $1.52 \mathrm{E}-03$ & 1.13E-04 & 1.03E-02 & 3.32E-03 & 7.13E-05 \\
\hline \multicolumn{14}{|c|}{ Cell L35-target $p H 7$} \\
\hline L35-3-1 & 4 & 91 & 7.53 & 2.87 & 0.396 & 0.05 & 9.35 & na & $1.77 \mathrm{E}-03$ & $1.69 \mathrm{E}-04$ & 1.33E-02 & $8.22 \mathrm{E}-03$ & na \\
\hline L35-3-2 & 6 & 90.3 & 8.02 & 3.17 & 0.343 & 0.05 & 7.56 & 0.05 & $1.62 \mathrm{E}-03$ & 1.35E-04 & $1.10 \mathrm{E}-02$ & 5.52E-03 & 5.71E-05 \\
\hline L35-3-3 & 8 & 91 & 7.75 & na & na & na & na & na & na & na & na & na & na \\
\hline L35-3-4 & 11 & 91.6 & 8.07 & 2.99 & 0.278 & 0.05 & 5.31 & na & $1.80 \mathrm{E}-03$ & 8.08E-05 & $1.30 \mathrm{E}-02$ & $4.56 \mathrm{E}-03$ & na \\
\hline L35-3-5 & 14 & 91.3 & 8.01 & 3.13 & 0.281 & 0.05 & 4.45 & 0.04 & $1.80 \mathrm{E}-03$ & $1.19 \mathrm{E}-04$ & $1.24 \mathrm{E}-02$ & 3.64E-03 & 4.28E-05 \\
\hline \multicolumn{14}{|c|}{ Cell L36 - target $p H 8$} \\
\hline L36-3-1 & 4 & 91 & 7.95 & 2.65 & 0.956 & 0.05 & 8.69 & na & $1.54 \mathrm{E}-03$ & 4.64E-04 & $1.25 \mathrm{E}-02$ & 7.23E-03 & na \\
\hline L36-3-2 & 6 & 90.3 & 8.4 & 2.7 & 0.766 & 0.05 & 7.83 & 0.02 & $1.56 \mathrm{E}-03$ & 3.65E-04 & $1.24 \mathrm{E}-02$ & $6.44 \mathrm{E}-03$ & 2.14E-05 \\
\hline L36-3-3 & 8 & 91 & 8.2 & na & na & na & na & na & na & na & na & na & na \\
\hline L36-3-4 & 11 & 91.6 & 8.5 & 2.69 & 0.725 & 0.05 & 3.48 & na & $1.62 \mathrm{E}-03$ & $3.60 \mathrm{E}-04$ & $1.30 \mathrm{E}-02$ & 2.96E-03 & na \\
\hline L36-3-5 & 14 & 91.3 & 8.34 & 2.75 & 0.588 & 0.05 & 3.35 & 0.03 & $1.78 \mathrm{E}-03$ & 3.05E-04 & $1.40 \mathrm{E}-02$ & 3.07E-03 & 2.41E-05 \\
\hline \multicolumn{14}{|c|}{ Cell L29-target $p H 8$} \\
\hline L29-3-1 & 4 & 91 & 7.98 & 2.64 & 1.02 & 0.05 & 8.16 & na & $1.70 \mathrm{E}-03$ & 5.47E-04 & $1.38 \mathrm{E}-02$ & 7.48E-03 & na \\
\hline L29-3-2 & 6 & 90.3 & 8.42 & 2.64 & 0.807 & 0.05 & 7.37 & 0.04 & $1.64 \mathrm{E}-03$ & 4.17E-04 & $1.34 \mathrm{E}-02$ & 6.55E-03 & 4.63E-05 \\
\hline L29-3-3 & 8 & 91 & 8.23 & na & na & na & na & na & na & na & na & na & na \\
\hline L29-3-4 & 11 & 91.6 & 8.72 & 2.54 & 0.626 & 0.05 & 3.73 & na & 1.43E-03 & $2.88 \mathrm{E}-04$ & $1.21 \mathrm{E}-02$ & 2.97E-03 & na \\
\hline L29-3-5 & 14 & 91.3 & 8.37 & 2.71 & 0.619 & 0.05 & 3.63 & 0.04 & $1.64 \mathrm{E}-03$ & 3.01E-04 & $1.30 \mathrm{E}-02$ & 3.11E-03 & 4.50E-05 \\
\hline \multicolumn{14}{|c|}{ Cell L33-target $p H 9$} \\
\hline L33-3-1 & 4 & 91 & 8.65 & 2.91 & 1.18 & 0.05 & 7.19 & na & $1.74 \mathrm{E}-03$ & $5.99 \mathrm{E}-04$ & $1.29 \mathrm{E}-02$ & $6.13 \mathrm{E}-03$ & na \\
\hline L33-3-2 & 6 & 90.3 & 9.13 & 2.83 & 1.27 & 0.05 & 5.23 & 0.05 & $1.57 \mathrm{E}-03$ & 5.99E-04 & 1.19E-02 & 4.12E-03 & 6.19E-05 \\
\hline L33-3-3 & 8 & 91 & 8.84 & na & na & na & na & na & na & na & na & na & na \\
\hline L33-3-4 & 11 & 91.6 & 9.1 & 2.72 & 1.7 & 0.05 & 3.51 & na & $1.55 \mathrm{E}-03$ & 8.22E-04 & 1.23E-02 & 2.83E-03 & na \\
\hline L33-3-5 & 14 & 91.3 & 9.06 & 2.75 & 1.19 & 0.05 & 0.329 & 0.03 & 1.89E-03 & 7.10E-04 & $1.48 \mathrm{E}-02$ & 3.24E-04 & 7.65E-05 \\
\hline \multicolumn{14}{|c|}{ Cell L31 - target $p H 9$} \\
\hline L33-3-1 & 4 & 91 & 8.69 & 3.01 & 2.41 & 0.05 & 7.25 & 0.05 & $1.67 \mathrm{E}-03$ & $1.14 \mathrm{E}-03$ & 1.19E-02 & 5.70E-03 & 1.98E-05 \\
\hline L33-3-2 & 6 & 90.3 & 9.12 & 2.88 & 3.99 & 0.05 & 7.37 & na & 5.12E-04 & $6.11 \mathrm{E}-04$ & 3.82E-03 & $1.86 \mathrm{E}-03$ & na \\
\hline L33-3-3 & 8 & 91 & 8.9 & 4 & 4.6 & 0.05 & 6.6 & na & 7.36E-04 & 7.30E-04 & 3.95E-03 & $1.64 \mathrm{E}-03$ & na \\
\hline
\end{tabular}


WSRC-TR-2005-00124

Revision 0

\begin{tabular}{|c|c|c|c|c|c|c|c|c|c|c|c|c|c|}
\hline $\begin{array}{c}\text { Sample } \\
\text { ID }\end{array}$ & $\begin{array}{c}\text { Day } \\
\text { sampled }\end{array}$ & $\begin{array}{c}\text { Temp } \\
\left({ }^{\circ} \mathrm{C}\right) \\
\end{array}$ & $\mathrm{pH}$ & $\begin{array}{c}\mathrm{C}_{\mathrm{Si}} \\
\mathrm{mg} \mathrm{L}^{-1}\end{array}$ & $\begin{array}{c}\mathrm{C}_{\mathrm{Al}} \\
\mathrm{mg} \mathrm{L}^{-1}\end{array}$ & $\begin{array}{c}\mathrm{C}_{\mathrm{S}} \\
\mathrm{mg} \mathrm{L}^{-1}\end{array}$ & $\begin{array}{c}\mathrm{C}_{\mathrm{Na}} \\
\mathrm{mg} \mathrm{L}^{-1}\end{array}$ & $\begin{array}{c}\mathrm{C}_{\mathrm{Re}} \\
\mu \mathrm{g} \mathrm{L}^{-1}\end{array}$ & $\begin{array}{c}\text { Rate Si } \\
\mathrm{g} \mathrm{m}^{-2} \mathrm{~d}^{-1}\end{array}$ & $\begin{array}{l}\text { Rate Al } \\
\mathrm{g} \mathrm{m}^{-2} \mathrm{~d}^{-1}\end{array}$ & $\begin{array}{c}\text { Rate } \mathrm{S} \\
\mathrm{g} \mathrm{m}^{-2} \mathrm{~d}^{-1}\end{array}$ & $\begin{array}{l}\text { Rate Na } \\
\mathrm{g} \mathrm{m}^{-2} \mathrm{~d}^{-1}\end{array}$ & $\begin{array}{l}\text { Rate Re } \\
\mathrm{g} \mathrm{m}^{-2} \mathrm{~d}^{-1}\end{array}$ \\
\hline L33-3-4 & 11 & 91.6 & na & na & na & na & na & na & na & na & na & na & na \\
\hline L33-3-5 & 14 & 91.3 & 9.08 & 2.86 & 3.19 & 0.05 & 3.53 & 0.04 & 1.38E-03 & $1.34 \mathrm{E}-03$ & $1.04 \mathrm{E}-02$ & $2.44 \mathrm{E}-03$ & 7.15E-05 \\
\hline \multicolumn{14}{|c|}{ Cell L24-target $p H 10$} \\
\hline L24-3-1 & 4 & 91 & 9.47 & 4.66 & 2.63 & 0.05 & 6.69 & na & 2.93E-03 & 1.42E-03 & 1.35E-02 & 5.48E-03 & na \\
\hline L24-3-2 & 6 & 90.3 & 9.98 & 4.69 & 2.51 & 0.05 & 5.58 & 0.08 & 2.68E-03 & 1.23E-03 & 1.23E-02 & 4.53E-03 & $1.27 \mathrm{E}-04$ \\
\hline L24-3-3 & 8 & 91 & 9.94 & na & na & na & na & na & na & na & na & na & na \\
\hline L24-3-4 & 11 & 91.6 & 9.93 & 4.54 & 2.13 & 0.05 & 4.4 & na & 2.70E-03 & 1.09E-03 & $1.28 \mathrm{E}-02$ & 3.71E-03 & na \\
\hline L24-3-5 & 14 & 91.3 & 9.72 & 4.36 & 2.08 & 0.05 & 3.99 & 0.06 & 2.59E-03 & 1.06E-03 & $1.28 \mathrm{E}-02$ & 3.36E-03 & 8.82E-05 \\
\hline \multicolumn{14}{|c|}{ Cell L28 - target $p H 10$} \\
\hline L28-3-1 & 4 & 91 & 9.48 & 4.21 & 1.97 & 0.05 & 7.02 & na & 2.40E-03 & $9.58 \mathrm{E}-04$ & 1.22E-02 & 5.23E-03 & na \\
\hline L28-3-2 & 6 & 90.3 & 9.86 & 4.42 & 2.4 & 0.05 & 5.3 & 0.04 & 2.76E-03 & 1.29E-03 & 1.34E-02 & 4.70E-03 & 4.64E-05 \\
\hline L28-3-3 & 8 & 91 & 9.93 & na & na & na & na & na & na & na & na & na & na \\
\hline L28-3-4 & 11 & 91.6 & 9.83 & 4.23 & 2.03 & 0.05 & 14.4 & na & 2.63E-03 & $1.08 \mathrm{E}-03$ & $1.34 \mathrm{E}-02$ & $1.28 \mathrm{E}-02$ & na \\
\hline L28-3-5 & 14 & 91.3 & 9.67 & 4.29 & 2.02 & 0.05 & 3.96 & 0.04 & 2.63E-03 & $1.06 \mathrm{E}-03$ & 1.32E-02 & $3.44 \mathrm{E}-03$ & 4.55E-05 \\
\hline \multicolumn{14}{|c|}{ Cell L25-target $p H 11$} \\
\hline L25-3-1 & -4 & 91 & 11.18 & 18.4 & 15.2 & 0.05 & 14.1 & na & $1.18 \mathrm{E}-02$ & 8.43E-03 & 1.38E-02 & 1.29E-02 & na \\
\hline L25-3-2 & 6 & 90.3 & 11.61 & 18.4 & 15.3 & 0.05 & 14.4 & 0.15 & 8.66E-03 & 6.23E-03 & 1.01E-02 & 9.67E-03 & 2.27E-04 \\
\hline L25-3-3 & 8 & 91 & 11.52 & na & na & na & na & na & na & na & na & na & na \\
\hline L25-3-4 & 11 & 91.6 & 11.64 & 15.8 & 12.3 & 0.05 & 11.9 & na & 8.97E-03 & 6.05E-03 & 1.22E-02 & 9.64E-03 & na \\
\hline L25-3-5 & 14 & 91.3 & 11.22 & 14.8 & 10.1 & 0.05 & 10.7 & 0.13 & 8.92E-03 & 5.24E-03 & $1.29 \mathrm{E}-02$ & 9.19E-03 & $2.46 \mathrm{E}-04$ \\
\hline \multicolumn{14}{|c|}{$\underline{\text { Cell L26-target } p H 11}$} \\
\hline L25-3-1 & 4 & 91 & 11.21 & 15.1 & 12.6 & 0.05 & 11.8 & na & 9.25E-03 & 6.68E-03 & 1.32E-02 & 1.03E-02 & na \\
\hline L25-3-2 & 6 & 90.3 & 11.68 & 15.5 & 12.9 & 0.05 & 12.6 & 0.14 & 9.79E-03 & 7.05E-03 & 1.36E-02 & 1.13E-02 & 2.81E-04 \\
\hline L25-3-3 & 8 & 91 & 11.48 & na & na & na & na & na & na & na & na & na & na \\
\hline L25-3-4 & 11 & 91.6 & 11.68 & 14.4 & 11 & 0.05 & 10.9 & na & 7.30E-03 & 4.82E-03 & 1.09E-02 & 7.87E-03 & na \\
\hline L25-3-5 & 14 & 91.3 & 11.23 & 13.6 & 8.6 & 0.05 & 10.3 & 0.11 & 8.46E-03 & 4.60E-03 & $1.34 \mathrm{E}-02$ & 9.13E-03 & 2.08E-04 \\
\hline
\end{tabular}

na $=$ not analyzed 
WSRC-TR-2005-00124

Revision 0

Table B2. Average of the Log of the Release Rates and Standard Deviations for tests with LAW 1173 bed product

\begin{tabular}{|c|c|c|c|c|c|c|c|c|c|c|c|c|}
\hline $\begin{array}{l}\text { Sample } \\
\text { ID }\end{array}$ & $\begin{array}{c}\text { Day } \\
\text { sampled }\end{array}$ & $\begin{array}{c}\text { Target } \\
\text { Temp } \\
\left({ }^{\circ} \mathrm{C}\right)\end{array}$ & $\begin{array}{c}\text { Average } \\
\text { Log Rate } \\
\text { Si } \\
\mathrm{g} \mathrm{m}^{-2} \mathrm{~d}^{-1}\end{array}$ & $\begin{array}{l}\text { Standard } \\
\text { Dev.. Si }\end{array}$ & $\begin{array}{c}\text { Average } \\
\text { Log Rate } \\
\mathrm{Al} \\
\mathrm{g} \mathrm{m}^{-2} \mathrm{~d}^{-1}\end{array}$ & $\begin{array}{c}\text { Standard } \\
\text { Dev. Al }\end{array}$ & $\begin{array}{c}\text { Average } \\
\text { Log Rate } \\
\mathrm{S} \\
\mathrm{g} \mathrm{m}^{-2} \mathrm{~d}^{-1}\end{array}$ & $\begin{array}{c}\text { Standard } \\
\text { Dev. S }\end{array}$ & $\begin{array}{c}\text { Average } \\
\text { Log Rate } \\
\mathrm{Na} \\
\mathrm{g} \mathrm{m}^{-2} \mathrm{~d}^{-1}\end{array}$ & $\begin{array}{l}\text { Standard } \\
\text { Dev. Na }\end{array}$ & $\begin{array}{c}\text { Average } \\
\text { Log Rate } \\
\text { Re } \\
\mathrm{g} \mathrm{m}^{-2} \mathrm{~d}^{-1}\end{array}$ & $\begin{array}{l}\text { Standard } \\
\text { Dev. Re }\end{array}$ \\
\hline \multicolumn{13}{|c|}{$\underline{\text { Cell L15/L18 - target } p H ~} 7$} \\
\hline Avg. & 4 & 70 & -3.04 & 0.14 & -3.68 & 0.13 & -1.86 & 0.01 & -1.92 & 0.08 & na & na \\
\hline Avg. & 6 & 70 & -3.09 & 0.13 & -3.81 & 0.12 & -1.87 & 0.02 & -2.31 & 0.06 & -4.10 & 0.07 \\
\hline Avg. & 11 & 70 & -3.02 & 0.11 & -4.09 & 0.21 & -1.82 & 0.05 & -2.36 & 0.08 & na & na \\
\hline Avg. & 14 & 70 & -3.01 & 0.08 & -3.93 & 0.13 & -1.82 & 0.03 & -2.52 & 0.01 & -4.28 & 0.03 \\
\hline \multicolumn{13}{|c|}{ Cell L20/L22-target $p H 8$} \\
\hline Avg. & 4 & 70 & -3.04 & 0.04 & -3.31 & 0.07 & -1.88 & 0.04 & -2.00 & 0.04 & na & na \\
\hline Avg. & 6 & 70 & -3.14 & 0.06 & -3.40 & 0.02 & -1.92 & 0.01 & -2.14 & 0.09 & -4.38 & 0.01 \\
\hline Avg. & 11 & 70 & -3.07 & 0.07 & -3.49 & 0.08 & -1.82 & 0.03 & -2.35 & 0.14 & na & na \\
\hline Avg. & 14 & 70 & -3.00 & 0.00 & -3.42 & 0.09 & -1.82 & 0.02 & -2.30 & 0.03 & -4.19 & 0.14 \\
\hline \multicolumn{13}{|c|}{ Cell L19L21 - target $p H 9$} \\
\hline Avg. & 4 & 70 & -2.88 & 0.11 & -2.79 & 0.14 & -1.86 & 0.07 & -2.09 & 0.09 & na & na \\
\hline Avg. & 6 & 70 & -2.96 & 0.00 & -3.18 & 0.45 & -1.86 & 0.05 & -2.23 & 0.02 & -4.08 & 0.14 \\
\hline Avg. & 11 & 70 & -3.08 & 0.09 & -3.21 & 0.13 & -1.90 & 0.11 & -2.39 & 0.10 & na & na \\
\hline Avg. & 14 & 70 & -2.94 & 0.02 & -2.96 & 0.01 & -1.85 & 0.06 & -2.48 & 0.12 & -3.97 & 0.01 \\
\hline \multicolumn{13}{|c|}{ Cell L09/L14-target $p H 10$} \\
\hline Avg. & 4 & 70 & -2.77 & 0.03 & -2.83 & 0.04 & -1.88 & 0.03 & -2.18 & 0.02 & na & na \\
\hline Avg. & 6 & 70 & -2.74 & 0.01 & -2.99 & 0.13 & -2.24 & 0.49 & -2.19 & 0.23 & -4.02 & 0.08 \\
\hline Avg. & 11 & 70 & -2.90 & 0.12 & -3.44 & 0.16 & -2.29 & 0.62 & -2.55 & 0.32 & na & na \\
\hline Avg. & 14 & 70 & -2.82 & 0.05 & -3.33 & 0.05 & -2.27 & 0.54 & -2.44 & 0.03 & -4.15 & 0.03 \\
\hline \multicolumn{13}{|c|}{ Cell L13/L10 - target $p H 11$} \\
\hline Avg. & 4 & 70 & -2.21 & 0.07 & -2.32 & 0.08 & -1.92 & 0.04 & -2.17 & 0.15 & na & na \\
\hline Avg. & 6 & 70 & -2.20 & 0.02 & -2.31 & 0.03 & -1.91 & 0.04 & -2.15 & 0.02 & -3.77 & 0.04 \\
\hline Avg. & 11 & 70 & -2.26 & 0.06 & -2.38 & 0.05 & -1.89 & 0.02 & -2.16 & 0.01 & na & na \\
\hline Avg. & 14 & 70 & -2.13 & 0.03 & -2.30 & 0.04 & -1.84 & 0.07 & -2.01 & 0.07 & -3.65 & 0.07 \\
\hline \multicolumn{13}{|c|}{ Cell L23/L35-target $p H 7$} \\
\hline Avg. & 4 & 90 & -2.76 & 0.01 & -3.76 & 0.02 & -1.88 & 0.01 & -2.06 & 0.04 & na & na \\
\hline Avg. & 6 & 90 & -2.78 & 0.02 & -3.82 & 0.07 & -1.93 & 0.03 & -2.19 & 0.10 & -4.16 & 0.12 \\
\hline Avg. & 11 & 90 & -2.75 & 0.01 & -4.07 & 0.03 & -1.89 & 0.01 & -2.36 & 0.03 & na & na \\
\hline Avg. & 14 & 90 & -2.78 & 0.05 & -3.93 & 0.02 & -1.95 & 0.06 & -2.46 & 0.03 & -4.26 & 0.16 \\
\hline
\end{tabular}


WSRC-TR-2005-00124

Revision 0

\begin{tabular}{|c|c|c|c|c|c|c|c|c|c|c|c|c|}
\hline $\begin{array}{l}\text { Sample } \\
\text { ID }\end{array}$ & $\begin{array}{c}\text { Day } \\
\text { sampled }\end{array}$ & $\begin{array}{l}\text { Target } \\
\text { Temp } \\
\left({ }^{\circ} \mathrm{C}\right)\end{array}$ & $\begin{array}{c}\text { Average } \\
\text { Log Rate } \\
\text { Si } \\
\mathrm{g} \mathrm{m}^{-2} \mathrm{~d}^{-1}\end{array}$ & $\begin{array}{l}\text { Standard } \\
\text { Dev.. Si }\end{array}$ & $\begin{array}{c}\text { Average } \\
\text { Log Rate } \\
\mathrm{Al} \\
\mathrm{g} \mathrm{m}^{-2} \mathrm{~d}^{-1}\end{array}$ & $\begin{array}{l}\text { Standard } \\
\text { Dev. Al }\end{array}$ & $\begin{array}{c}\text { Average } \\
\text { Log Rate } \\
\text { S } \\
\mathrm{g} \mathrm{m}^{-2} \mathrm{~d}^{-1}\end{array}$ & $\begin{array}{l}\text { Standard } \\
\text { Dev. S }\end{array}$ & $\begin{array}{c}\text { Average } \\
\text { Log Rate } \\
\mathrm{Na} \\
\mathrm{g} \mathrm{m}^{-2} \mathrm{~d}^{-1}\end{array}$ & $\begin{array}{l}\text { Standard } \\
\text { Dev. Na }\end{array}$ & $\begin{array}{c}\text { Average } \\
\text { Log Rate } \\
\text { Re } \\
\mathrm{g} \mathrm{m}^{-2} \mathrm{~d}^{-1}\end{array}$ & $\begin{array}{l}\text { Standard } \\
\text { Dev. Re }\end{array}$ \\
\hline \multicolumn{13}{|c|}{ Cell L36/L29-target $p H 8$} \\
\hline Avg. & 4 & 90 & -2.79 & 0.03 & -3.30 & 0.05 & -1.88 & 0.03 & -2.13 & 0.01 & na & na \\
\hline Avg. & 6 & 90 & -2.80 & 0.02 & -3.41 & 0.04 & -1.89 & 0.02 & -2.19 & 0.01 & -4.50 & 0.24 \\
\hline Avg. & 11 & 90 & -2.82 & 0.04 & -3.49 & 0.07 & -1.90 & 0.02 & -2.53 & 0.00 & na & na \\
\hline Avg. & 14 & 90 & -2.77 & 0.03 & -3.52 & 0.00 & -1.87 & 0.02 & -2.51 & 0.00 & -4.48 & 0.19 \\
\hline \multicolumn{13}{|c|}{ Cell L33/L31- target $p H 9$} \\
\hline Avg. & 4 & 90 & -2.77 & 0.01 & -3.08 & 0.20 & -1.91 & 0.02 & -2.23 & 0.02 & na & na \\
\hline Avg. & 6 & 90 & -3.05 & 0.34 & -3.22 & 0.01 & -2.17 & 0.35 & -2.56 & 0.24 & -4.46 & 0.35 \\
\hline Avg. & 11 & 90 & -3.13 & 0.23 & -3.14 & 0.04 & -2.40 & 0.35 & -2.78 & 0.17 & na & na \\
\hline Avg. & 14 & 90 & -2.79 & 0.10 & -3.01 & 0.19 & -1.91 & 0.11 & -2.61 & 0.00 & -4.13 & 0.02 \\
\hline \multicolumn{13}{|c|}{ Cell L24/L28 - target $p H 10$} \\
\hline Avg. & 4 & 90 & -2.58 & 0.06 & -2.93 & 0.12 & -1.89 & 0.03 & -2.27 & 0.01 & na & na \\
\hline Avg. & 6 & 90 & -2.57 & 0.01 & -2.90 & 0.01 & -1.89 & 0.03 & -2.34 & 0.01 & -4.11 & 0.31 \\
\hline Avg. & 11 & 90 & -2.57 & 0.01 & -2.96 & 0.00 & -1.88 & 0.01 & -2.16 & 0.38 & na & na \\
\hline Avg. & 14 & 90 & -2.58 & 0.00 & -2.98 & 0.00 & -1.89 & 0.01 & -2.47 & 0.01 & -4.20 & 0.20 \\
\hline \multicolumn{13}{|c|}{ Cell L25/L26 - target $p H 11$} \\
\hline Avg. & 4 & 90 & -1.98 & 0.07 & -2.12 & 0.07 & -1.87 & 0.01 & -1.94 & 0.07 & na & na \\
\hline Avg. & 6 & 90 & -2.04 & 0.04 & -2.18 & 0.04 & -1.93 & 0.09 & -1.98 & 0.05 & -3.60 & 0.07 \\
\hline Avg. & 11 & 90 & -2.09 & 0.06 & -2.27 & 0.07 & -1.94 & 0.04 & -2.06 & 0.06 & na & na \\
\hline Avg. & 14 & 90 & -2.06 & 0.02 & -2.31 & 0.04 & -1.88 & 0.01 & -2.04 & 0.00 & -3.65 & 0.05 \\
\hline
\end{tabular}




\section{Distribution:}

E. W. Holtzscheiter, SRNL

D. A. Crowley, 999-W

S. L. Marra, 999-W

T. B. Calloway, 999-W

N. E. Bibler, SRNL

J.C. Marra, SRNL

D.K. Peeler, 999-W

J. R. Harbour, SRNL

C.A. Langton, SRNL

A.D. Cozzi, SRNL

G. G. Wicks, SRNL

P. R. Burkett, SRNL

External Distribution:

William Owca, DOE-ID

Billie Mauss, DOE-ORP

Michael Cowen, THOR Treatment Technologies, LLC

Brad Mason, Studsvik, Inc.

Kevin Ryan, THOR Treatment Technologies, LLC

Arlin Olson, Idaho National Laboratory 